Portland State University

PDXScholar

The Small Business Development Center Program: From a Small Business Growth Stage and Adult Learning Perspective

Roy Otis Kruger

Portland State University

Follow this and additional works at: https://pdxscholar.library.pdx.edu/open_access_etds Let us know how access to this document benefits you.

Recommended Citation

Kruger, Roy Otis, "The Small Business Development Center Program: From a Small Business Growth Stage and Adult Learning Perspective" (1991). Dissertations and Theses. Paper 1356.

https://doi.org/10.15760/etd.1355

This Dissertation is brought to you for free and open access. It has been accepted for inclusion in Dissertations and Theses by an authorized administrator of PDXScholar. Please contact us if we can make this document more accessible: pdxscholar@pdx.edu. 


\title{
THE SMALL BUSINESS DEVELOPMENT CENTER PROGRAM: \\ FROM A SMALL BUSINESS GROWTH STAGE \\ AND ADULT LEARNING PERSPECTIVE
}

\author{
by \\ ROY OTIS KRUGER \\ A dissertation submitted in partial fulfillment of the \\ requirements for the degree of \\ DOCTOR OF EDUCATION \\ in \\ EDUCATIONAL LEADERSHIP \\ Portland state University \\ (c) 1991
}


TO THE OFFICE OF GRADUATE STUDIES:

The members of the committee approve the dissertation of Roy otis Kruger presented on February 19, 1991.

Mary K. Kinnick, Chair

फolgla J. Robertson

Morton S. Malter

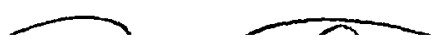

Richard L. Brinkman

LeWis N. GosIin

APPROVED :

Robert B.'Everhart, Dean, School of Education

C. William Savery, Interim ViCe Provost for Graduate studies and Research 
AN ABSTRACT OF THE DISSERTATION OF ROY Otis Kruger for the Doctor of Education in Educational Leadership presented February 19, 1991.

Title: The Small Business Development Center Program: From a Small Business Growth Stage and Adult Learning Perspective

APPROVED BY MEMBERS OF THE DISSERTATION COMMITTEE:

Maty K. Kinnick, Chair

Doughats J. Robertson

-. - .

Morton S, Mater

Richard L. Brinkman

Zeฟ้is N. Goslin

The study of the Clackamas Small Business Development Center (SBDC) Small Business Management Programs (SBM) had three research objectives: to ascertain what information 
transferred to small business owners and how best to transfer that information; to ascertain what information is presently being transferred to clients and what methods are used in transferring the information; and to survey clients in order to develop a current demographic profile, measure their level of satisfaction with the assistance received, and ascertain what they perceived were the benefits of the program to their companies.

Prior to the study, there had been little systematic research of what information should be transferred to SBDC clients and the most effective methods for transferring that information. The small business growth stage literature was used to develop the recommended body of information. The adult learning literature was used to develop the recommended methods for transferring that information to clients.

The majority of respondents were women, well educated, middle- aged, and from companies in service related industries that employed few workers. The findings suggest that clients desire an increase in both the appropriateness of the program's informational content and the level of their involvement in tailoring the SBM program to the needs of their organizations. As suggested by the Small Business Growth Stage Models, a statistically significant decline in client satisfaction of the program's informational content 
was found to exist between stage two and stage three business owners.

The study found that instructors did not utilize specific business factors (such as sales levels, numbers of employees, etc.) in developing the informational content of the SBM programs. Instructors also did not utilize client preferred learning styles, or formal client involvement in developing the instructional design of the SBM program.

The study found that clients and center personnel appear to differ in their perceptions regarding the role of the instructor and the purpose of the SBM program. Clients appear to envision the role the instructor as more of a consultant, while instructors view their role as preparing clients to solve their own problems. 


\section{ACKNOWLEDGMENTS}

I wish to express my sincere appreciation to the people who have assisted and supported me throughout this study. I am grateful to Professors Brinkman, Goslin, Malter, and Robertson for their challenging ideas, scholarly interest, and invaluable assistance in the development and completion of the research project.

Particular appreciation is expressed to Mary Kinnick, Ph.D., for her time, guidance, source of ideas, and encouragement that have substantially contributed to the design and completion of this study.

The assistance of the following individuals is greatly appreciated: Bob Ellis, Director, Clackamas Community College Small Business Development Center, Hal Bergmann, Director, Portland Community College Small Business Development Center, and the staffs of both Small Business Development Centers.

Appreciation is expressed to Joel Arick, Ph.D., for his guidance in the computer analysis and interpretation of the data.

A special thanks goes to my wife, Glenna. Without her continued encouragement and support, this study might not have been completed. She devoted many long hours to editorial assistance and her sense of patience and 
encouragement were always a welcome relief. 
ACKNOWLEDGEMENTS . . . . . . . . . . . . . . . . iii

LIST OF TABLES • . . . . . . . . . . . . . . . . viii

CHAPTER

I INTRODUCTION . . . . . . . . . . . . . 1

Problem statement . . . . . . . . 11

Purpose Statement . . . . . . . . 12

Definitions Utilized in the Study . . . 15

Small Business

Small Business Development Center Program (SBDC)

oregon Small Business Development Center Network (OSBDCN)

clackamas Community College Small Business Center (Clackamas Center)

Small Business Management Program clients

Study Limitations . . . . . . . . . 16

II REVIEW OF THE LITERATURE • • • • • • • • • • 17

Needs of Small Businesses at Different

Stages of Growth . . . . . . . 17

Small Business Growth Stage Models

Pre-stage one Company

Stage one Company

Stage Two Company

Stage Three Company

Stage Four Company

Stage Five Company

Implications for the Study . . . . . 37

Adult Learning Desires and Expectations . 38 
Kolb's Learning style Model

Implications for the study

Small Business Development Center Program History Section . . . . . . 48

History of the oregon Small Business Development Center Network History of the clackamas Small Business Development Center

Conclusions . . . . . . . . . 55

Phase I: Client Survey . . . . . . 58

Research Objectives

Research Design

Questionnaire Design

Key Dependent Variables

Counseling section

Greenhouse/Small Business Management Section

Key Descriptive Independent Variables

Preferred Instructional styles

Small Business Growth Stage

Data Collection Procedures

Data Analysis

Phase II: Clackamas Center Personnel

Interviews . . . . . . . . . 71

Research Design

Personal Interview Questionnaire Development

Data collection

Analysis of Data

ANALYSIS AND DISCUSSION . . . . . . . 76

Client Survey Response Rate . . . . . 76

1989 Client Profile . . . . . . . . 78

Summary of client Profile Findings

Analysis of Program Content . . . . . 84 


$$
\begin{aligned}
& \text { Hypotheses Testing } \\
& \text { Analysis of Hypotheses Testing } \\
& \text { Analysis of Program Instructional and } \\
& \text { Curricular Design . . . . . . . } 100 \\
& \text { Perceived Benefits of Assistance . . . } 103 \\
& \text { Summary of overall study Findings . . . } 104 \\
& \text { V SUMMARY, CONCLUSIONS, AND RECOMMENDATIONS • . } 107 \\
& \text { Summary . . . . . . . . . . } 107 \\
& \text { Conclusions . . . . . . . . . . . } 112 \\
& \text { Recommendations to Program Developers . } 119 \\
& \text { Recommendations for Policy Makers . . } 120 \\
& \text { Recommendations for Future Research . . } 121
\end{aligned}
$$

REFERENCES . . . . . . . . . . . . . . . . 124 APPENDICES

A CLACKAMAS SMALL BUSINESS DEVELOPMENT CENTER CLIENT SURVEY • • • • • • • • • • • • • • 132

B CLACKAMAS SMALL BUSINESS DEVELOPMENT CENTER PERSONNEL INTERVIEW QUESTIONNAIRE . . • . • . 138

C SMALL BUSINESS INFORMATIONAL CONTENT AND INSTRUCTIONAL DESIGN PROGRAM CHECKLIST • • • 143

D CLIENT SURVEY TOTALS • . . . • . • • . . 149

E TOTAL RESPONSE PROFILE OF SHORT-TERM COUNSELING AND SMALL BUSINESS MANAGEMENT PROGRAMS DIMENSION VARIABLES . . . . . . . 160

F COMPARISON OF CLIENTS AND CENTER PERSONNEL RESPONSES TO QUESTIONS REGARDING PROGRAM INSTRUCTIONAL AND CURRICULAR DESIGN ISSUES . . . . . . . . . . . . . . 162

G SMALL BUSINESS DEVELOPMENT CENTER RESEARCH • 166 H SUMMARY OF CLACKAMAS CENTER INTERVIEWS . . . 170 
viii

APPENDICES

PAGE

I GREENHOUSE AND SMALL BUSINESS MANAGEMENT • . 176 CURRICULUM 


\section{LIST OF TABLES}

\begin{tabular}{|c|c|c|c|c|}
\hline I & Labor Productivity Growth Rates, 1950-86 & . • & • & 2 \\
\hline II & $\begin{array}{l}\text { Drucker's seven Sources of "Innovative } \\
\text { Opportunity", } 1990 . \cdot \cdot \cdot \cdot \bullet^{\cdot} \cdot \cdot \text {. }\end{array}$ & 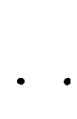 & & 8 \\
\hline III & $\begin{array}{r}\text { Characteristics of Companies at Different } \\
\text { Stages of Growth, } 1990 . \cdot \text {. } \cdot \text {. . . }\end{array}$ & $\cdot \cdot$ & - & 23 \\
\hline IV & $\begin{array}{r}\text { Comparison of Professional Management and } \\
\text { Owner Dominated Management, } 1990 . \text {. }\end{array}$ & $\cdot \cdot$ & • & 28 \\
\hline $\mathrm{V}$ & $\begin{array}{c}\text { oregon Small Business Development Center } \\
\text { Network Budget, } 1988 \cdot{ }^{*} \cdot \bullet^{*} \cdot \cdot \cdot \cdot\end{array}$ & $\cdot \cdot$ & - & 54 \\
\hline VI & 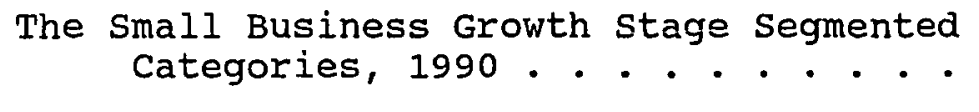 & by & - & 64 \\
\hline VII & $\begin{array}{c}\text { Reliability Scores of Key Counseling Progr } \\
\text { Dependent Variables, } 1990 \text {. . . . }\end{array}$ & & • & 69 \\
\hline VIII & $\begin{array}{c}\text { Reliability Scores of Key Small Business } \\
\text { Management Program Dependent Variable } \\
1990 . .\end{array}$ & es, & - & 70 \\
\hline IX & 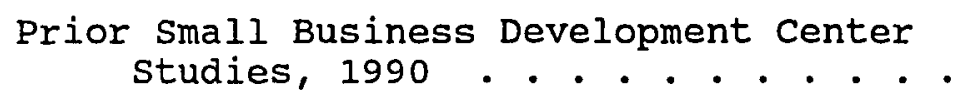 & & - : & 77 \\
\hline $\mathrm{x}$ & Number of Years in operations, 1990 . . & $\cdot \cdot$ & $\cdot$ & 79 \\
\hline $\mathrm{XI}$ & 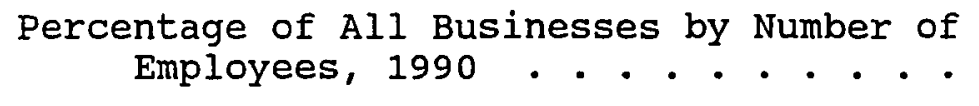 & & $\cdot \cdot$ & 80 \\
\hline XII & $\begin{array}{c}\text { Respondents by Small Business Growth Stage } \\
1990 . \\
\end{array}$ & e, & $\cdot \cdot$ & 81 \\
\hline$X I I I$ & Respondents by Industry, 1990 . . . . • • & - & • & 81 \\
\hline $\mathrm{XIV}$ & Respondents by Age, 1990 . • . . . . • . & $\cdot$. & - $\cdot$ & 82 \\
\hline $\mathrm{XV}$ & Educational Background of Respondents, 199 & 90 & - & 83 \\
\hline XVI & $\begin{array}{l}\text { Specific Problem Areas for Which Responder } \\
\text { Sought Assistance, } 1989 \text {. . . . . . }\end{array}$ & & & \\
\hline
\end{tabular}


XVII Respondent Evaluation of Informational Content Program Variables for the shortterm Counseling and Small Business Management Programs, 1990 . . . . . 85

XVIII

Comparison of Respondents and Center Personnel Preferences of Instructor's Instructional Role, $1990 .$. ............ 87

XIX Comparison of Respondents and Center Personnel Preferences of client Involvement in Class Sessions, 1990 . . . . . . . . 88

XX Results of Chi-Square Tests Between Key Independent Demographic Variables and the Small Business Growth Stage, 1990 . .90

XXI F-Test Ratios of Short-term Counseling Variables by Small Business Growth Stage (Number of Employees), 1990 . . . . . . 91

XXII F-Test Ratios of short-term Counseling Variables by Small Business Growth Stage (Dollar Amount of Assets), 1990 . . . . 92

XXIII

F-Test Ratios of Small Business Management Program Variables by Small Business Growth Stage (Number of Employees), 1990 . . . 93

XXIV F-Test Ratios of Small Business Management Program Variables by Small Business Growth Stage (Dollar Amount of Assets), 1990 . . 94

XXV Significant Program Variables by Client Small Business Growth Stage, 1990 . . . . . 95

XXVI Tukey-Cramer Comparison Tests for significance Small Business Management Program Variable: Appropriate Information by Small Business Growth Stage (Number of Employees), 1990.96

XXVII Tukey-Cramer Comparison Tests for Significance Small Business Management Program Variable: Instructor's knowledge by Small Business Growth Stage (Number of Employees), 1990 . 97 
XXVIII Tukey-Cramer Comparison Tests for Significance Small Business Management Program Variable: Instructor's Knowledge by Small Business Growth Stage (Dollar Amount of Assets), 1990 ................ 98

XXIX Respondent Evaluation of Instructional and Curricular Program Variables for Small Business Management Programs, 1990. . 101

XXX Instructional and Curricular Involvement Desired by Clients, 1990... . . . . 101

XXXI Best Instructional Methods for Learning to Take Place, 1990 ......... 102

XXXII Client Perceived Benefits of the Program, 1991 
CHAPTER I

INTRODUCTION

During the 1970s and 1980s, the long-term ability of the United States to compete effectively in international markets became an increasingly debated issue within the U.S. economic community (Baumol \& McLennen, 1985; Baily \& Blair, 1988; Mishel, 1989; Neef \& Thomas, 1987; President's Commission, 1985). Economists disagreed as to whether the U.S. manufacturing sector had succeeded in reversing its long-term trend in declining Labor Productivity Growth Rates that began in the early 1970s (Baily \& Chakrabarti, 1988, p. 180). Some economists suggest that the declining trend in productivity growth rates experienced during the 1970 s had been corrected during the 1980s (Nau, 1990; Nye, 1990; President's Commission, 1985). Other economists suggest that the apparent labor productivity reversal is actually a short-term phenomena rather than a long-term correction (Baily \& Blair, 1988; Baumol \& McLennen, 1985; Cuomo Commission, 1988; Mishel, 1989; Thurow, 1985). This is an important question because both the current level of labor productivity and its long-term growth are major factors that influence a nation's international competitiveness and standard of living (Baumol, 1985, p. 3). 
This apparent turnaround in labor productivity can be seen in Table I, which compares the Labor Productivity Growth rates among France, Germany, Japan, United Kingdom, and the United States from 1950 through 1986.

TABLE I

LABOR PRODUCTIVITY GROWTH RATES

1950-86

\begin{tabular}{llcc}
\hline Period & France & United & United \\
Kingdom & States \\
\hline
\end{tabular}

Percent Growth of Gross Domestic Product (GDP) per employed person

$\begin{array}{llllll}1950-73 & 4.55 & 4.99 & 7.21 & 2.53 & 1.96 \\ 1973-79 & 2.65 & 2.78 & 2.87 & 1.30 & 0.03 \\ 1979-86 & 1.85 & 1.58 & 2.72 & 1.71 & 0.82\end{array}$

Percent Growth of GDP per hour, total economy

$\begin{array}{llllll}1950-73 & 5.01 & 5.83 & 7.41 & 3.15 & 2.44 \\ 1973-79 & 3.83 & 3.91 & 3.40 & 2.18 & 0.80 \\ 1979-86 & 3.24 & 1.88 & 3.06 & 2.95 & 1.09\end{array}$

Percent Growth of GDP per hour, manufacturing sector

$\begin{array}{llllll}1950-73 & 5.63 & 6.31 & 9.48 & 3.25 & 2.62 \\ 1973-79 & 4.90 & 4.22 & 5.39 & 0.83 & 1.37 \\ 1979-86 & 3.50 & 2.78 & 5.47 & 4.28 & 3.10\end{array}$

Note. Adapted from Innovation and the Productivity Crisis ( $p$. 180 ) by M. N. Baily and A. K. Chakrabarti, 1988, Washington, DC: The Brookings Institution.

Baumol (1985) credits this upturn in manufacturing productivity rates to the increased utilization of plant and equipment in relation to the overall level of employment experienced in 1983, after the severe 1981-1982 economic recession ( $p .4)$. This increase in manufacturing sector 
productivity after a recessionary period is a normally expected phenomena. However, Baumol (1985) and Mishel (1989) have found some disturbing characteristics associated with this latest manufacturing productivity turnaround. Baumol (1985) found that the productivity increase for the entire private sector was smaller in 1983 than any comparable recovery period since World War II, even though the productivity increase for the manufacturing sector alone was larger than any comparable time period (p. 4). Mishel (1989) contends that there is an actual broad-based decline in the manufacturing sector productivity, taking the following factors into consideration: there were two million fewer manufacturing employees at the end of the 1980s than there were in 1979 ; the growth of sales and investment within the economy lagged significantly below the 1970s level; and we have experienced a persistent manufacturing trade deficit (p. 35) .

other economists have suggested that manufacturing productivity rates have been overly influenced by the dynamic expansion of the computer and defense industries (Baily \& Blair, 1988, p. 180; Mishel, 1989, p. 35); the dramatic decline of the exchange rate of the dollar in relation to other major currencies (Neef, 1987, p. 25); and the inaccurate measurement tools developed and utilized by government agencies to measure productivity (Mishel, 1989, p. 36). 
The causes for the 1979-1986 upturn in manufacturing productivity rates appear to be multi-faceted. The evidence suggests that by the end of the 1980 s productivity increases had been experienced by relatively few industries (agriculture and computers), and millions of manufacturing jobs had been eliminated. An important issue is how to increase productivity across all sectors of the economy while increasing the level of employment at the same time. Schumpeter's (1911/1983) paradigm of the role of the entrepreneur provides a useful conceptual framework from which to analyze this issue.

Schumpeter credits the entrepreneur with maintaining the health and economic vitality of capitalism through the continual introduction of new technological innovation into the market place. Without this continual introduction of new firms into the market place, industries become increasingly dominated by small groups of large corporations oblivious to new technological innovation and changing customer needs. Schumpeter suggested that in the long-run, the successful entrepreneur would force all firms to adopt the new technology in order to compete in the market place. As these new forms of technological innovation are dispersed across the total economy, a continually evolving series or "stages" of economic equilibrium takes place (Taylor, 1971, p. 26). Although the movement of a society's economic sector is highly influenced by the nation's present 
economic stage, cultural history, and geographical location, it is the infusion of new technology by the entrepreneur that provides for the dynamics of the process (Taylor, 1971, p. 31).

A number of economists have suggested that it is this evolution throughout sequential stages of economic equilibrium that differentiates the "Economic Development" needed for long term productive growth from mere "Economic Growth" (Brinkman, 1981; De Gregori, 1985; Myrdal, 1974). De Gregori (1985) has defined economic growth as an increase in a society's national per-capita income, while economic development is an increase in national per-capita income through a fundamental change in the eccnomic structure of that society (p. 7). This fundamental change in the economic structure permeates the total social structure and culture of a particular society (Hoselitz et al., 1960, p. 202). This "holistic" understanding of culture as the sum of man's knowledge, both the material objects utilized by a society and the social structure of that society was originally introduced by Tylor in 1871 (Kroeber \& Kluckhow, 1952, p. 43-46). Thus a society's culture can be thought of as a whole composed of two parts: the material part and the non-material part. When new scientjfic knowledge, in the form of new technological innovation, is applied to either a society's material objects or social structure, there is a concomitant change in the other part (Brinkman, 1981). The 
results of this concomitant change in the society's technological structure are higher levels of efficiency, effectiveness, and productivity which are ultimately reflected in increased international competitiveness, levels of employment, and higher standards of living.

This economic development paradigm suggests that the evolutionary structural change of a society's macroeconomic sector is a three step process. The first step is the development of new scientific knowledge which will ultimately provide a productivity advantage through the improvement of products, production processes, and/or management efficiency and effectiveness. The second step is. the technological innovation stage, where entrepreneurs apply this new scientific knowledge to specific products, production processes, and/or management systems as they enter the market place. The third step is the dissemination of this technological innovation across the total economic sector. Thus the successful completion of all three steps is important for the long-term productivity growth of the U.S. economy.

Baumol (1985) has found that in addition to the utilization of new innovations by industry, increasing the level of skills and knowledge of the work force is a major influence on increasing long-term productivity (p. 4). However, a persistent problem within the U.S. economy appears to be the failure of businesses to utilize new 
technological developments and effectively manage their operations (Myers, 1990, p. A1). An underlying reason for this persistent failure of companies to utilize new technologies may be the absence of a "Systematic Entrepreneurship" perspective on the part of their management (Drucker, 1985, p. 21).

Drucker suggests that it is the creation and utilization of "new knowledge" that increases innovation and higher skill levels (1969, p. 158-159). Drucker goes on to describe the development of this new knowledge as the direct result of the entrepreneur's systematic analysis and exploitation of seven sources of "innovative opportunity" (see Table II).

The successful utilization of each source of innovative opportunity requires a close relationship with and/or knowledge of the customer by the entrepreneur. There are many examples of large corporations successfully exploiting innovative opportunities. The larger the organization, the more financial and personnel resources should be available for new knowledge development and adaption. However, a number of analysts have observed that when organizations experience rapid growth, openness to new technological innovations and changing customer needs becomes more difficult (Bottomore, 1981, p. 23; Churchill \& Lewis, 1983, p. 40; Drucker, 1969, p. 151, 1985, p. 147; Greiner, 1972, 
TABLE II

DRUCKER'S SEVEN SOURCES OF "INNOVATIVE OPPORTUNITY" 1990

\begin{tabular}{ll}
\hline \multicolumn{1}{c}{ Source } & \multicolumn{1}{c}{ Description } \\
\hline Unexpected Situations & $\begin{array}{l}\text { Unexpected successes or } \\
\text { failures of business } \\
\text { strategies }\end{array}$ \\
Incongruous Situations & $\begin{array}{l}\text { Failures of competitors to } \\
\text { understand changes in } \\
\text { customer expectations }\end{array}$ \\
Process Needs & $\begin{array}{l}\text { Development of more } \\
\text { effective production } \\
\text { methods }\end{array}$ \\
Market structural Changes & $\begin{array}{l}\text { Rapid growth of specific } \\
\text { markets }\end{array}$ \\
Demographic Changes & $\begin{array}{l}\text { Inherent changes in } \\
\text { population }\end{array}$ \\
Customer Perception Changes & $\begin{array}{l}\text { Major changes in } \\
\text { perceptions held by market } \\
\text { segments }\end{array}$ \\
New Knowledge Development & $\begin{array}{l}\text { Development of new } \\
\text { scientific and } \\
\text { nonscientific knowledge }\end{array}$ \\
\hline
\end{tabular}

Note. Adapted from Innovation and entrepreneurship: Practice and principle by P. F. Drucker, 1985, New York: Harper \& Row.

p. 43; Schumpeter, 1911/ 1983). Large corporations can become increasingly distant from their customers and must continually work hard at developing structures and systems that facilitate change and customer awareness.

Birch's (1984, 1987) empirical studies of the job creation activities of millions of small businesses suggest 
that they have made major contributions to the economic growth and development of the United States. After experiencing a doubling of employment between 1954 and 1970, the Fortune 500 companies employed 1.2 million fewer workers in 1983 than in 1973 (Birch, 1984, p. 15). By 1984, the total number of employees eliminated by these Fortune 500 companies had grown to 1.5 million workers (Solomon, 1986, p. 10). Between 1980 and 1982, while the large business sector was eliminating $1,664,000$ jobs, the small business sector was creating $2,650,000$ new jobs (Cutler, 1984, p. 30). Thus an important consideration is how to effectively foster the utilization of new innovations within the small business sector in order to create employment and increased productivity.

Researchers have found that it is the owner's managerial skills and the availability of capital that are the major causes of small business failures (Peterson, Kozmetsky, Ridgway, 1983, p. 17; Steinmetz, 1969, p. 31). Besides finding sources of additional capital, one major criteria for a program designed to assist small businesses is its ability to influence and improve the managerial and administrative skills of owners. There are a number of ways in which the improvement of an owner's administrative knowledge and skills can be approached. The U.S. Small Business Administration (SBA) and numerous state and local economic development agencies have developed an array of small business assistance programs from providing loan guarantees to offering retired 
executives as mentors. The services of private consultants and special workshops can be utilized. Another approach is to utilize a systematic educational program in an attempt to insure that there is consistency of curricular objectives, informational content, and instructional methodology in assisting business owners. One such educational program designed to systematically improve the managerial and administrative abilities of owners is the small Business Development Center (SBDC) Program.

The SBDC program is a nationwide collective of state partnerships comprised of the SBA, state and local economic development agencies, and the appropriate local state university and/or college system. With its inception in 1980 , the major goal of the SBDC program has been to assist both in the development of new small businesses and the growth of already existing companies. The oregon small Business Development Center Network (OSBDCN) was established in September 1984. By 1988, OSBDCN had grown to 22 individual centers statewide and had a budget of $\$ 2,994,314$.

Although SBDC assistance has taken many forms, the two major programs in Oregon are the Short-term counseling and Small Business Management (SBM) Programs. The Short-term Counseling Program provides counselors to assist clients in finding solutions to very specific business problems. All clients seeking assistance participate in an initial Short-term counseling session. From there they are directed 
to the SBM Program, individual workshops, or other resources depending on their particular needs.

The success of the SBM program in improving the managerial skills of owners is particularly pertinent for Oregon because of the state's heavy concentration of small businesses. The Oregon Department of Economic Development estimated that in 1989, 99 percent of all oregon businesses had less than 500 employees (p. 6). During the period 1982 through 1987, firms with less than 20 employees created all of the 113,000 new jobs in the state (p. 1). The remaining portion of this chapter will discuss the problem and purpose statements, definitions, and limitations of this study.

\section{PROBLEM STATEMENT}

Although the national Small Business Development Center Program has been in place for the past decade, most research has concentrated on conducting cost/benefit studies as a way of establishing the worth of the SBDC program (Chrisman, Nelson, Hoy, \& Robinson, 1985; Elstrott 1987; Pelham, 1985). These studies have compared the estimated tax revenue generated by clients to the costs of funding the SBDC program. Finding that tax revenues have been greater than funding costs, researchers have concluded that the SBDC program is worthy of continued funding. There are two issues that arise out of using this methodology. The first issue is whether the revenue increases are only the result of SBDC assistance or 
other contributing factors. The second issue relates to the use of the SBDC revenue output as a measure of its own effectiveness. Although a case can be made that a positive cost/benefit analysis is one measure of effectiveness, the methodology begs the question of whether the funds could have been used more effectively in another manner.

None of these studies has analyzed the appropriateness of the information or the way in which that information is given to clients. This study analyzed the SBM program in terms of the operational needs of the business and the learning needs of the owner.

\section{PURPOSE STATEMENT}

The purpose of this study was to analyze the contribution made by the Small Business Management Program to improving the managerial and administrative skills of clients. The first step in the analysis process was to ascertain the clients' evaluation of the curricular and instructional design of the program. The second step was to compare the actual curricular and instructional design of the program with an ideal design based on the small business growth and adult learning literatures.

This study had three research objectives: to ascertain what information should be transferred to small business owners and how best to transfer that information; to ascertain what information is presently being transferred to clients and 
what methods are used in transferring that information; and to survey SBDC clients and develop a current demographic profile, measure their level of satisfaction with the assistance received, and ascertain what they perceived were the benefits of the program to their companies.

The first research objective was accomplished through the extensive utilization of both the small business growth stage literature and the adult learning literature. What is known of the informational needs of small businesses at various stages of organizational growth was used as a model of what should be the ideal informational content of an assistance program for SBDC clients (Churchill \& Lewis, 1983; Greiner, 1972; Steinmetz, 1969). Likewise, what is known of the desires, expectations, and special curricular and instructional issues of adult learners was utilized as the ideal model for the SBDC program (Brookfield, 1986; Cross, 1981; Daloz, 1986; Wlodkowski, 1985).

The second research objective was accomplished through a series of in-depth, on-site interviews with personnel at the Clackamas Community College Small Business Development Center (Clackamas center). These eight individuals were counselors and instructors directly involved in the short-term counseling and Small Business Management (SBM) programs, which are the major assistance programs offered by the clackamas Center. The "ideal" informational and instructional criteria were used to evaluate the materials, processes, procedures, and factors 
utilized by the clackamas center in designing and administering these programs.

Although most individual centers within OSBDCN have a SBM program, the decision was made to limit the research study to the clackamas center for two reasons. The first reason was the difficultly in controlling for the wide diversity of informational content and delivery formats of SBM programs at the individual centers if a network wide study was chosen. The decision was made to select one program for analysis, and as a part of the evaluation process, to develop the criteria, procedures, and processes that could be utilized by other centers to evaluate their individual programs. The second reason was that the clackamas Center was one of the first centers to implement a SBM program.

The third objective was accomplished through a client survey of all individuals (488) who contacted the clackamas Center for assistance during 1989. The responses from this survey were utilized to identify who had used the short-term Counseling and SBM programs, how satisfied they were with the informational content, curricular design, and instructional design of these programs, and what they perceived as the benefit of the assistance to their company. 
DEFINITIONS UTILIZED IN THE STUDY

\section{Small Business}

A company independently owned and operated, not dominant within its industry, and with 500 employees or less. (Oregon Department of Economic Development, p. 6; Solomon, 1986, p. 21).

Small Business Development Center Program (SBDC)

A nationwide collective of state partnerships comprised of the U. S. Small Business Administration (SBA), state and local economic development agencies, and the appropriate local state university and/or college system.

Oregon Small Business Development Center Network (OSBDCN)

A collective partnership between the federal government, state government, and the postsecondary community, which is involved in assisting the establishment, and fostering the development of small businesses within oregon.

Clackamas Community college

Small Business Development Center (Clackamas Center)

An individual SBDC center within OSBDCN and housed at clackamas Community college. 
Small Business Management

Program Clients

Those individuals who have participated in one or more of the Clackamas Center's Greenhouse Program, Small Business Management I Program, and Small Business Management II Program.

\section{STUDY IIMITATIONS}

The major limitation of this study is its generalization to the total Oregon Small Business Development Network (OSBDCN) program and to other Small Business Development Center (SBDC) programs within other states. However, it is hoped that this study will provide the criteria and instruments needed for evaluating the programs of other centers and providing SBDC administrators with added information to make decisions regarding current and future assistance programs. 
CHAPTER II

REVIEW OF THE LITERATURE

Chapter I discussed the need for exploring both the type of information that should be transferred to small businesses and what mechanisms should be utilized in transferring that technology. In order to accomplish those objectives, chapter II is divided into three sections. Section one reviews the small business growth stage literature. Section two reviews the adult learning literature. Section three reviews the history of the small Business Development Center Program, nationally, within Oregon, and specifically at the clackamas center.

NEEDS OF SMALL BUSINESSES AT DIFFERENT STAGES OF GROWTH

Developing a conceptual framework from which to understand the changing needs of small businesses as they grow from inception to large corporations is the first step in understanding what causes small businesses to fail. Business failure has been defined in a number of ways. The United States Small Business Administration (SBA) defines business failure as any situation where an organization is forced to discontinue operations (Croft, 1987, p. 17). Analysts utilizing this definition have estimated that over 
50 percent of all new businesses fail within the first four years of their existence, and that this number might increase to between 80 and 90 percent of all new businesses if all "homebased and sideline businesses" are included (Croft, 1987, p. 17). Steinmetz (1969) suggests that a small business fails when the original company loses its identity through a merger with a larger company (p. 30-31). However, defining business failure simply in terms of the cessation of operations or losing organizational identity through merger proceedings presents important measurement problems. The cessation of operations of a small business may be a result of personal decisions rather than economic considerations. Some economically viable companies are closed as owners make transitions in their own lives, such as working for someone else, starting a new company, pursuing non-economic interests, retiring, or selling the business for a profitable return. Because of the complexities involved in identifying when cessation of operations and losing organizational identity is not a part of the owner's goals, business failure will be defined as the forced discontinuance of operations caused by legal bankruptcy proceedings (Fredland \& Morris, 1976, p. 7; White, 1983, p. 115). This would include both bankruptcy proceedings that were forced upon the organization by outside parties and litigation voluntarily sought by owners of the business. 
Churchill and Lewis (1983) have found that there are key owner related and organizational related factors that influence the success of the business throughout its lifetime (p. 40). The key owner related factors are the individual's short-term and long-term personal and business goals, operational abilities, managerial abilities, and strategic planning abilities. The key organizational factors are the level and depth of financial resources, personnel resources, and operational systems. A number of researchers suggest that the owner's ability to obtain and maintain an adequate level of financial resources appears to be a crucial factor in influencing long-term business viability (Cohn \& Lindberg, 1974; Edmunds, 1982; Joint Legislative Interim Task Force on Small Business, 1978, p. 47 ; Peterson, Kozmetsky, \& Ridgway, 1983, p. 17). Research has shown that as businesses grow in size, their increasing organizational complexity requires qualitative changes in these key owner and organizational factors (Churchill \& Lewis, 1983; Greiner, 1972; Steinmetz, 1969). Thus management abilities and organizational structures that were appropriate for the very small business are no longer appropriate for the large corporation. Utilizing a sequential stage growth model is useful in analyzing the dynamic organizational and structural changes that take place as a small business evolves into a large company. The major small business growth stage models are 
those developed by Steinmetz (1969), Greiner (1972), and Churchill and Lewis (1983).

\section{Small Business Growth Stage Models}

Steinmetz (1969) developed a three stage growth model that focuses on the critical issues related to company size (number of employees, dollars of assets), supervision style, and control. During the first stage of growth, the typical owner/manager exercises very close control over the operation and the activities of employees. Based on empirical studies, steinmetz (1969) suggests that as the growing business approaches the first stage threshold (25 30 employees; $\$ 500,000-\$ 750,000$ in assets) it becomes too large for one individual to effectively control and direct all operations. In order to accommodate the organizational complexity, the organization must develop a rudimentary management structure consisting of a layer of lower level managers or supervisors (p. 31). Successfully accomplished, the business is now a stage two company.

During the second stage, more of the day-to-day responsibilities are delegated to the lower level managers, which allows the company to continue to grow until the next crisis point is reached $(250-300$ employees; $\$ 7-\$ 10$ million in assets). At this point the business needs an organizational structure and operating systems capable of assisting the company in obtaining and effectively utilizing new resources. Successfully accomplished, the business is 
now a stage three company. The successful company continues to adapt increasingly sophisticated organizational structures and operating systems as it finally makes the final transition into a large corporation as it surpasses the the stage three threshold $(750-1,000$ employees; $\$ 25-$ $\$ 50$ million in assets).

Greiner (1972) developed a five phase model that focuses on the crisis that creates the need for organizational change, and the appropriate response of a business to that need. The crisis point during phase 1 is company growth beyond the owner's ability to manage. The appropriate organizational response is the implementation of some form of professional manager/lower level manager organizational system. The crisis point for phase 2 is when the business grows beyond the professional manager's ability to manage everything. The appropriate organizational response is the implementation of a decentralized decision making process. The crisis point for phase 3 is when top management lacks the ability to control and coordinate the company's operations through the decentralized decision making process. The appropriate response during phase 4 is the implementation of formalized company-wide systems for planning, coordination, and evaluation of operations. The crisis point of phase 4 is when these formalized systems impede the organization's ability to make rapid decisions. The appropriate response during phase 5 is the "development 
of an organizational philosophy and structure that fosters mutual respect, cooperation, and prompt solutions to problems" (p. 41).

Utilizing the theoretical models of Steinmetz (1969) and Greiner (1972) and their own empirical research, Churchill and Lewis (1983) expanded Steinmetz's basic growth stage model into two additional stages (five stages in total). A major assumption of Churchill and Lewis is the importance of separating the goals and objectives of the owner from the life of the organization (p. 31). Although their model does not assume that all small businesses must enter all five stages of growth, there is the implicit expectation that all companies will evolve as far as the third stage in order to become viable entities.

A modified Churchill and Lewis model will be used as a guide in the following discussion of the managerial and operational system needs of small businesses at different stages of growth. The model has been modified to include a pre-stage one company to encompass the prospective small business owner that would participate in the Greenhouse Program. Table III presents the "number of employees" and "dollar amount of assets" characteristics that differentiate companies at the beginning of each stage of growth. 
TABLE III

\section{CHARACTERISTICS OF COMPANIES AT \\ DIFFERENT STAGES OF GROWTH 1990}

\begin{tabular}{ccc}
\hline Stage & $\begin{array}{c}\text { Number of } \\
\text { Employees }\end{array}$ & $\begin{array}{c}\text { Dollar Amount } \\
\text { Of Assets }\end{array}$ \\
Pre-one & 0 & 0 \\
One & Owner & Start-up Capital \\
Two & Below 25 & Below $\$ 500$ Thousand \\
Three & 25 & $\$ 500$ Thousand \\
Four & 250 & $\$ 7$ Million \\
Five & 500 & $\$ 25$ Million \\
\hline
\end{tabular}

Note. Adapted from "The Five stages of Small Business Growth" by N. C. Churchill and V. L. Lewis, 1983, Harvard Business Review, 61, p. 30. "Critical stages of Small Business Growth: When they occur and how to survive them" by L. L. Steinmetz, 1969, Business Horizons, 12, p. 29 .

\section{Pre-stage one company}

The pre-stage one company is the new business idea that needs to be evaluated with respect to its long-term feasibility. Stevenson, Roberts and Grousbeck (1985) suggests that a comprehensive feasibility study needs to include the following key issues:

1) Why does the business opportunity exist?

- Technological change.

- Government regulation.

- Shifts in market demand.

2) What are the dimensions of the business opportunity? 
- Market size.

- Time frame.

- Growth potential.

3) What are the needs met by the product or service?

4) What are the key risks is starting a new business?

- Customers.

- Competitors.

- Management weaknesses.

- Technological changes.

5) What is the value of the business opportunity?

- What is the financial return in terms of:

- Capital requirements

- Increased risk

- Time requirements

6) What nonfinancial personal awards are provided by the opportunity?

7) What are the prospective owner's personal requirements? - Goals.

- Skills and interests.

- Risk acceptance/avoidance (p. 17-18).

Prospective owners are ready to start their business if they find that the new venture is both personally and financially viable. Major factors to consider are the individual's managerial and administrative abilities and the sufficiency of the capital available to the new business. These two factors have been found to be major causes of 
small business failures (Peterson, Kozmetsky, \& Ridgway, 1983, p. 17; Steinmetz, 1969, p. 31).

Delaney (1984) found from his research that the following mistakes were major contributing factors to business failure: continued employee/employer informality; not delegating decision making; providing poor direction and control; making decisions for nonbusiness reasons; nepotism; not enough emphasis upon correcting operating problems ( $p$. 87).

Thus, an important part of an educational program designed for individuals contemplating starting a new business should be to assist them in assessing their own long-term personal and professional goals, their managerial knowledge, skills, and abilities, and the potential that actually exists for their prospective business venture. A particularly important concern is whether individuals who successfully start new businesses have the ability and/or inclination to modify their own leadership styles as the organization grows.

\section{Stage one Company}

At the beginning of stage one the new owner must rapidly secure the needed resources and equipment to produce a quality product or service, develop a market niche to ensure a stable cash flow, and implement quality production and distribution systems before the original capital is depleted (Churchill \& Lewis, 1983, p. 31-32; Flamholtz, 
1986, p. 70). Steinmetz (1969) estimates that fifty percent of all new businesses fail at this stage before the owner is able to successfully achieve these three tasks (p. 31).

The informational needs of the stage one company would be very similar to those of the pre-stage one company. Stevenson's seven key issues would be instrumental in assisting business owners in focusing on essential resources, market niches, and operating systems necessary for their survival. If the owner is able to successfully establish the business, the organization is ready to make the transition into stage two.

\section{Stage Two Company}

During the second stage the focus of the small business owner shifts from one of mere existence to rapidly increasing the cash flow to the company (Churchill \& Lewis, 1983, p. 34). The major reason for this shift is that once a company is initially established, it must quickly secure a creditable market niche large enough to ensure its long term profitability, security, and existence. A creditable market niche not only yields a level of profits and cash flow that is sufficient to sustain the long term existence of the company, but it also meets the return on investment (ROI) goals and criteria of the business owner (Churchill and Lewis, 1983, p. 34). During this stage, capital requirements rise rapidly to cover the added complexity and greater size needed to secure and service an increased 
market niche. If the owner is unable to achieve a creditable market niche, it is unlikely that the company will be able to obtain the needed resources to remain a viable entity.

It is during stage two that the successful small business makes the transition from an owner dominated to a professionally managed organization. Table IV compares the significant differences that exist in key operational areas between the owner dominated and professionally managed organization.

At the beginning of stage two, the organizational structure of the owner dominated company is relatively simple. The owner directly supervises the activities of all employees and there is little development of lower level managers. Planning systems consist mainly of cash forecasting (Crean \& Farber, 1987, p. 30). However, as the level of sales begins to grow, both the owner and the organization face a crisis of leadership brought about by the firm's increasing success (Greiner, 1972, p. 41). As the size of the firm increases in response to increased sales, the complexity of the operations also increases. The owner is no longer able to do everything, and he or she must now come to depend upon other people to accomplish his or her objectives. With the additional employees come increasing personnel, paperwork, and facility requirement problems. As the level of organizational complexity 
TABLE IV

COMPARISON OF PROFESSIONAL MANAGEMENT

AND OWNER DOMINATED MANAGEMENT

1990

\begin{tabular}{|c|c|c|}
\hline $\begin{array}{l}\text { Key } \\
\text { Operational } \\
\text { Areas }\end{array}$ & $\begin{array}{l}\text { Professional } \\
\text { Management }\end{array}$ & $\begin{array}{c}\text { Owner } \\
\text { Dominated } \\
\text { Management }\end{array}$ \\
\hline Profit & $\begin{array}{l}\text { Profit orientation: } \\
\text { is explicit goal. }\end{array}$ & $\begin{array}{l}\text { Profit seen as a } \\
\text { by-product. }\end{array}$ \\
\hline Planning & $\begin{array}{l}\text { Formal, systematic } \\
\text { planning: } \\
\text { - Strategic planning } \\
\text { - Operational planning } \\
\text { - Contingency planning }\end{array}$ & $\begin{array}{l}\text { Informal, ad hoc } \\
\text { planning. }\end{array}$ \\
\hline organization & $\begin{array}{l}\text { Formal, explicit role } \\
\text { descriptions that are } \\
\text { exclusive and } \\
\text { exhaustive. }\end{array}$ & $\begin{array}{l}\text { Informal } \\
\text { structure with } \\
\text { overlapping and } \\
\text { undefined } \\
\text { responsibilities. }\end{array}$ \\
\hline Control & $\begin{array}{l}\text { Formal, planned } \\
\text { system of organiza- } \\
\text { tional control in- } \\
\text { cluding explicit } \\
\text { objectives targets, } \\
\text { measures, evaluations, } \\
\text { and rewards. }\end{array}$ & $\begin{array}{l}\text { Partial, ad hoc } \\
\text { control; seldom } \\
\text { uses formal } \\
\text { measurements. }\end{array}$ \\
\hline $\begin{array}{l}\text { Management } \\
\text { Development }\end{array}$ & $\begin{array}{l}\text { Planned Management } \\
\text { development: } \\
\text { - Identification of } \\
\text { requirements. } \\
\text { - Design of programs. }\end{array}$ & $\begin{array}{l}\text { Ad hoc } \\
\text { development, } \\
\text { principally } \\
\text { through on-the- } \\
\text { job training. }\end{array}$ \\
\hline Budgeting & $\begin{array}{l}\text { Management by } \\
\text { standards and } \\
\text { variances. }\end{array}$ & $\begin{array}{l}\text { Budget not } \\
\text { explicit; no and } \\
\text { follow-up on } \\
\text { variances. }\end{array}$ \\
\hline Innovation & $\begin{array}{l}\text { Orientation to } \\
\text { incremental innova- } \\
\text { tions; willingness } \\
\text { to take calculated } \\
\text { risks. }\end{array}$ & $\begin{array}{l}\text { Orientation to } \\
\text { major innova- } \\
\text { tions; } \\
\text { willingness to } \\
\text { take major risks. }\end{array}$ \\
\hline
\end{tabular}


TABLE IV
COMPARISON OF PROFESSIONAL MANAGEMENT
AND OWNER DOMINATED MANAGEMENT
1990
(continued)

\begin{tabular}{lll}
\hline $\begin{array}{c}\text { Key } \\
\text { Operational } \\
\text { Areas }\end{array}$ & $\begin{array}{c}\text { Professional } \\
\text { Management }\end{array}$ & $\begin{array}{c}\text { Owner } \\
\text { Dominated } \\
\text { Management }\end{array}$ \\
\hline Leadership & $\begin{array}{l}\text { Consultative or } \\
\text { participative } \\
\text { styles. }\end{array}$ & $\begin{array}{l}\text { Styles may vary } \\
\text { from very } \\
\text { directive to } \\
\text { laissez-faire. }\end{array}$
\end{tabular}

Note. Adapted from How to Make the Transition from an Entrepreneurship to a Professionally Managed Firm ( $p$. 42) by E. G. Flamholtz, 1986, San Francisco: JosseyBass Publishers.

continues to grow, the owner must continually shift from strictly a technical orientation to a managerial orientation that encompasses responsibilities such as recruiting, selecting, developing, and training new employees (Steinmetz, 1969, p. 31).

Researchers have found that it is the small business owner's own personality rather than company resources or market opportunities that is most likely to limit the business' ability to make the organizational changes needed for this stage and subsequent growth stages (Barnes \& Hershon, 1976; Flamholtz, 1986, p. 113; Hofer \& Charan, 1984, p. 4). Those very creative, individualistic, and technically-related skills of the owner which were so important in originally establishing the business have now 
become increasingly detrimental to the organization as the firm continues to grow in size and complexity.

The atmosphere within the organization must, out of necessity, begin to become more formalized. There are too many employees for the owner to continue to closely supervise everyone. Where once all employees communicated with and had direct access to the owner, there is now the development of lower levels of management separating employees from the owner. Where once organizational activities were directly influenced and prioritized by immediate communication with customers, companies now experience a greater increase in competition and increasing alienation from the customers (Greiner, 1972, p. 42; Steinmetz, 1969, p. 32)

The increasing complexity of the firm makes it important to delegate more of the planning and managing responsibilities of the organization to professional managers who have the skills to develop the more sophisticated production systems, financial controls, employee supervision methods, planning methods, organizing structures, and controlling procedures that will be needed as the company continues to grow. The involvement of small business owners is crucial in the transitional process from an individually managed organization to a professionally managed organization. If these small business owners already possess good managerial skills and abilities, they 
can begin delegating additional responsibilities to lower level managers. If, however, these owners do not already possess these skills, they must decide whether they are willing or able to learn these managerial skills and abilities or whether to bring in a professional manager to manage the day-to-day operations of the organization. Scott and Bruce (1987) who utilized the Churchill and Lewis model in their studies, suggest it is the combination of internal organizational pressures and external forces that propel the stage two company with its rudimentary professional management structure into the next stage of growth (p. 47). Two major external factors that influence the organization at this stage are the potential need for additional financing and the reaction of competitors.

If the organization is successful and the level of sales increases, additional funds and working capital such as lines of credit or short term loans must be obtained in order to finance the accompanying increase in inventories and receivables. Additional expenses are incurred as the firm expands its channel of distribution in order to reach new customers.

If the company has developed a new market which is becoming profitable, larger competitors may decide to enter the market place. The speed with which this is done depends upon the uniqueness of the product or production process. The more unique the product or the production process, the 
more time the company will have to obtain the needed capital to expand and improve its production facilities and be protected from the strategies of its competitors.

An important aspect of an educational program for owners of a stage two company is an assessment of their managerial and organizational skills that will be needed for continued organizational growth and complexity. Another aspect of the program should focus on implementing appropriate planning, organizing, and controlling systems within firms.

\section{Stage Three Company}

At the beginning of stage three, the company's identity is still largely synonymous with that of its owner (Churchill \& Lewis, 1983, p. 34). The organizational size, number of employees, and formal systems are still relatively limited. Scott and Bruce (1987) suggest that many small businesses at this stage of growth will begin the process of new product development and broaden their limited product line (p. 48). The company wili begin to explore the possibility of using multiple marketing channels to reach their customers. Now that the business has achieved a sufficient and stable level of profitability and cash flow to maintain its existence, the owner has the opportunity to develop long term plans related to the desired level of growth for the organization. Churchill and Lewis (1983) 
suggest that owners choose either a disengagement or continued growth strategy (p. 34).

A disengagement strategy is primarily for owners who are interested in maintaining an organization that will provide them with an adequate level of income while allowing them to be involved in other interests. The owner actually makes a partial withdrawal from managing the company. To successfully achieve a disengagement strategy the owner must make sure basic financial, marketing, and production systems are in place along with a limited number of professional managers to insure that the present level of sales, profits, and cash flow are maintained. Over time the company will develop an identity separate from that of the owner and will have a good opportunity to maintain its present niche or be marketed to an interested buyer. An ever present danger is that as the company matures, it may be unable to adapt to changing environmental forces and fail or become a marginally surviving company (stage two) again.

A continuing growth strategy is the utilization of business resources to the fullest for further growth. In order to grow, the organization must also develop the additional sources of financing needed to fund and sustain the anticipated growth in both the level of sales and organizational complexity.

Two critical factors during this stage are the ability of the owner to delegate increased levels of responsibility 
and the ability of lower level managers to make effective decisions (Greiner, 1972, p. 42). As the company continues to grow, there will be an increasing demand and need for more decentralized decision making and managing on the part of lower level managers. The organization must begin the process of either recruiting or developing managers who have the capability and capacity to manage the systems of the present firm and begin the process of establishing and implementing the more complex and sophisticated planning, accounting, cost, and production systems that the company will need during the rapid growth of the forth stage. Strategic planning must become an integral part of the organization's planning process (Churchill \& Lewis, 1983, p. 34). Griener (1972) found that during this stage, organizations begin developing company-wide programs, such as stock option and profit sharing plans which are designed to both motivate employees and create a unifying organizational identity (p. 43).

Demand for expansion into new markets becomes increasingly important as the company experiences additional competitive pressures (Scott \& Bruce, 1987, p. 50). If the firm's competitors have access to greater financial resources, the pressure on price, profit, and cash flow may be very crippling to the organization. If the company is unsuccessful in achieving a sustained growth strategy, the owner may sell his or her interest in the organization to 
another party or find that the firm has been forced to regress back to a prior stage. An important part of an educational program for owners of a stage three company would be to assist them in ascertaining what their long-term growth goals for the company. Based on their stage three goals of disengagement or growth, long-term planning can be utilized to insure that the organizational structure to be developed for the business is appropriate.

\section{Stage Four Company}

The major organizational concerns of this stage relate to the consequences of very rapid growth and methods of how to finance and maintain that growth. By the end of this stage, the organization has evolved into a large company. Edmunds (1982) found that the chief cause of a successful business failing at this stage of growth was that its sales and facilities expanded at a faster rate than the cash flow to pay for the expansion (p. 24).

As the company expands during this stage at an accelerating rate, the continual delegation of additional responsibilities and increased participation in planning by lower levels of managers becomes a critical priority for the firm.

The mere size and complexity of the firm creates a complex bureaucracy that limits the participation of individual managers in the total operations of the organization (Griener, 1972, p. 43). Operating managers 
resent the involvement of staff personnel in the operations and planning of their departments. The successful

resolution of this organizational crisis is necessary if the institution is going to have the spontaneity in management action and planning that external and internal changes and pressures require.

Some methods for increasing management spontaneity include solving problems through the use of project teams comprised of employees from all functional areas, reducing the number of staff personnel, and simplifying the formal systems that have evolved within the organization. Systems and programs need to be designed and implemented that enhance communications, increase management training, and provide access to current, up-to-date information. Reward systems should focus on project team accomplishments rather than individual achievements (Greiner, 1972, p. 43).

\section{Stage Five Company}

The stage five company is no longer a small business and must consolidate the financial gains derived from its rapid growth during the take-off stage and develop systems that will allow for the continual responsiveness to the market place. The danger for a company during this stage is a drifting and decline brought about by an "ossification" mentality which is "characterized by the lack of innovative decision making and the avoidance of risks" (Churchill \& Lewis, 1983, p. 40). Thus the organization must be 
concerned with expense control and productivity while seeking additional market opportunities. Greiner (1972) suggests that a major cause of ossification may be the total exhaustion of management brought about by the intensity of problem solving and development of innovative systems that are instituted during the fourth stage (p. 44).

The company that is unable to successfully consolidate its financial resources may find itself forced to downsize to the lowest stage that its encumbered resources allow.

\section{IMPLICATIONS FOR THE STUDY}

The Churchill and Lewis (1983) model suggests that management and operational systems and structures within an organization must change as the firm continues to experience dynamic growth within and across subsequent growth stages. Thus specific skills, knowledge, and systems that are appropriate for one stage of growth are less appropriate for another stage of growth. Since the model assumes increasing complexity at each sequentially higher growth stage, it can be assumed that a program designed specifically to assist businesses at the early stages of growth would be less appropriate for firms at the later stages of growth.

The informational content of the clackamas center assistance programs is primarily designed to assist prospective owners in conducting business feasibility studies and to provide business owners with the basic 
rudimentary management skills and systems for their companies. The programs make no attempt to differentiate between clients of varying growth stages. If the assumption is made that no specific set of skills and systems is equally appropriate for businesses at: all growth stages, then a logical assumption would be that the appropriateness of the informational content (the set of skills and systems) of the clackamas Center programs would be evaluated differently by owners of firms at different growth stages. Another logical assumption would be that a program appropriate for firms at a lower growth stage would become increasingly less appropriate at each sequentially higher growth stage.

\section{ADULT LEARNING DESIRES AND EXPECTATIONS}

An important issue for a program designed for adult learners, such as the SBDC program, is whether its instructional and curricular design is consistent with the educational desires and expectations of clients. Knowles (1970) developed an early adult learning theory (andragogy) that explored what major differences might exist between the adult learner and the traditional-age learner (individuals normally 22 years old and under) and the implications of those differences. Knowles's initial assumptions were that adults are self-directed learners, use prior experiences as an integral part of learning, seek job or other social role 
related learning, and are interested in immediate application of learning to solve problems (p. 39). Knowles (1984) later expanded the theory to incorporate the assumption that motivation of adult learners move from external rewards (better jobs, higher salaries, etc.) to intrinsic rewards (self-esteem, self-actualization, etc.) (p. 12)

Knowles has come under increasing criticism by many adult educational theorists for the lack of empirical evidence to support all of the assumptions of the Andragogy model (Brookfield, 1986, p. 95; Cross, 1981, p. 225). Brookfield (1986) questions the assumptions that the movement from external dependence to internal self-directness is chronologically based, that adult learning efforts are primarily problem centered, and that adults always immediately seek to apply what they have learned (p. 121). A number of researchers suggested that the attributes described by Knowles' Andragogy theory are displayed in varying degrees among adults based upon their individual differences in experiences and cognitive development (Aslanian \& Brickell, 1980; Cross, 1981; Kegan, 1982; King, 1978; Knox, 1986; Perry, 1981). These differences in cognitive development result from highly complex and unique ways in which individuals experience the interrelated effects of biological, psychological, and social-economic changes in their lives. 
The Nottingham Andragogy Group has suggested that Andragogy should be reconceptualized as the process of assisting adults to develop their own critical thinking and awareness (Brookfield, 1986, p. 100). Even Knowles (1984) has come to understand the concept of Andragogy as a system that incorporates the attributes of the concept Pedagogy as one of the elements within its structure (p. 8).

A major catalyst for individuals to seek a reconstruction of their world view is the "trigger events" (such as new jobs, marriage, divorce, death, etc.) that cause individuals to call into question many of the concepts and assumptions that they have previously considered to be true (Aslanian \& Brickell, 1980, p. 37). Aslanian and Brickell (1980) found from their study of 2,000 men and women that most of the educational goals of the adult learners were directly related to trigger events in their lives (p. IX).

Knox (1986) stresses the importance of establishing an atmosphere of mutual respect between the instructor and adult learner. This relationship should underscore the position of adult learners as equal and joint partners in their own learning process (p. 45). However, there is a need to make modifications in the planning and execution of the program based on the level of self-directness of the individual. Knox suggests that a program designed for the passive adult learner who is still dependent on an outside 
authority figure should have very specifically prescribed objectives, packaged content, and achievement-reiated testing. The correct corresponding role of the instructor would be one of a "transmitter of knowledge and judge of learner achievement" (p. 25).

For the self-directed learner the program should be modified to include extensive participation on the part of the individual in such activities as self-assessment, "contract learning," small group discussion, problem solving, and simulation. The role of the instructor in such a situation is one of assisting learners to analyze ideas more deeply through higher level reasoning, to identify and plan strategies to achieve the desired proficiencies, to recognize and appreciate differing perspectives, and to logically examine differing assumptions and values (Knox, 1986, p. 25).

The concept of lifelong learning has been used to refer to all deliberate educational experiences by individuals to increase their knowledge and skills. These educational experiences range from learning completed in the work place to very formalized courses taken in a traditional educational setting. Researchers have found that from $79 \%$ to $90 \%$ of adults are actively involved in some form of "Iifelong learning" experience every year throughout their lifetime (Peterson, 1981, p. 309; Tough, 1981, p. 296). Tough (1981) found that $80 \%$ of his subjects were 
self-directed learners who had prepared their own

educational objectives and programs (p. 298).

Adult learners are motivated to be actively involved in lifelong learning for a variety of reasons. An early study

of the reasons why adults were involved in learning

activities was conducted by Houle. Following a series of

intensive interviews, Houle (1963) segmented adult learners

into three distinct groups based upon their educational

goals and outcomes: Goal-oriented Learners, Activity-

Oriented Learners, and Learning-oriented Learners (p. 15) .

Goal-oriented Learners established educational goals and

outcomes that related to achieving specific personal and/or

professional objectives. Activity-oriented learners

primarily sought additional educational opportunities as a vehicle for developing new friendships. Learning-oriented learners on the other hand, focused on the intrinsic value of learning new knowledge for its own sake.

Cross (1981) suggests that the level of motivation adult learners have to successfully achieve their specific learning goals is directly related to the Expectancy-Valence Theory (p. 126). The Expectancy-Valence Theory assumes the intensiveness with which individuals seek to accomplish specific goals is directly related to the priority level of that goal in their lives and the level of probability of achieving that goal (Vroom, 1967). Thus the higher the priority level of the goal and the higher the likelihood of 
success in achieving that goal, the higher the motivational level of the individual.

A person's age, psychological make-up, level of income, and ranking within one's career path are also very important factors in determining the educational goals and outcomes that will be sought by the individual. The more an individual is likely to gain from learning additional skills (higher levels of income, promotions, etc.), the more likely continuing educational goals will be practical and career related (Cross, 1981, p. 207; Knox, 1986, p. 67). The client of a SBDC program is highly likely to be a self-directed, Goal- Oriented Learner. The starting of a new business is a major "trigger event" for most people and creates the need to learn new skills and knowledge. Thus the instructor or program developer should work in conjunction with the adult learner to:

1) Assess and agree upon what skills and additional knowledge are needed.

2) Develop a learning plan which incorporates a specific time frame and a selected list of educational activities and experiences that will assist the learner in obtaining the needed skills and knowledge.

3) Develop an agreed upon method of evaluating the success of each educational experience separately and together as a total comprehensive program. 
Cross (1981) has found in her studies of adult learners, that individuals desire to be actively involved in the planning, implementation, and evaluation of their educational program by a "two- to-one margin" (p. 212). The more involved individuals are in the planning process, the more likely they will successfully complete that program. Individuals develop more realistic estimates of the time and energy that will be actually required to achieve their educational objectives (Knox, 1986, p. 73). An assessment of the students' progress in successfully achieving their objectives should be done on an on-going basis throughout the educational program (Knox, 1986, p. 57). This continual evaluation process is instrumental in maintaining the student's level of motivation and involvement in the program.

The instructor should work closely with adult learners to assess their current skill and knowledge proficiencies. Methods that can be employed to do this are: self-assessment inventories, performance records, supervisory reports, direct observations, tests, and interviews (Knox, 1986, p. 6). The difference between the current level of proficiency and the desired level of proficiency is the "diagnosed learning need" around which the educational program must be developed (Knowles, 1984, p. 18).

Once the "diagnosed learning need" is developed, the student in collaboration with the instructor should: 
1) Select the most effective resources and strategies for accomplishing each objective.

2) Specify what evidence will be collected and utilized to evaluate whether the objective was accomplished.

3) Specify how the evidence will be validated (Knowles, 1984, p. 18-19).

Kolb (1984) suggests that the effectiveness of

educational programs can be increased through the process of matching instructor teaching styles with student learning preferences.

\section{Kolb's Learning style Model}

From his studies in the area of student learning, Kolb (1984) developed an integrated, four phase learning cycle model. The four phases of his model are: "Concrete Experience, Reflective Observation, Abstract Conceptualization, and Active Experimentation." These four phases are paired with each other across two dimensions. The Concrete Experience Phase and the Abstract Conceptualization Phase are at the opposite ends of what Kolb calls the "Grasping dimension" of learning. This dimension focuses on a person's preference for grasping or obtaining new information. The Reflective Observation Phase and the Active Experimentation Phase are at the opposite ends of the "Transforming dimension" of the model. This dimension focuses on a person's preference for making and utilizing new information as one's own. Both the Grasping 
and Transforming dimensions relate the learning process and how individuals prefer to learn and utilize new information. Kolb suggests that the most effective way to learn is to first become involved in "hands on" activities (Concrete Experience Phase), reflect upon those activities (Reflective Observation Phase), develop a system of abstract principles out of reflecting upon their activities (Abstract Conceptualization Phase), and finally apply the principles they have developed to new situations (Active Experimentation Phase). Kolb (1981) found that most individuals prefer certain phases of the learning cycle, and that they could be categorized in one of four learning groups depending on their abstract-concrete and active-reflective dimension preferences (p. 237-238). He labeled these partial learning preference groups, "Convergers," "Divergers," "Assimilators," and "Accommodators."

"Convergers" prefer the abstract conceptualization and active experimentation phases. They wish to be presented with one practical solution to their problem. "Divergers" prefer the concrete experience and reflective observation phases. They generate new ideas by analyzing their experiences from many different perspectives. "Assimilators" prefer the abstract conceptualization and reflective observation phases. They enjoy developing new principles through deductive reasoning. "Accommodators" 
prefer the concrete experience and active experimentation phases. They are risk takers who are comfortable with trial and error methods to find a solution. However, Accommodators tend to rely on others for solutions rather than relying on their own problem solving abilities.

Kolb (1981) found from his empirical studies of college Business Administration majors, that as a group they tended to be accommodator style learners. If the accommodator learning style preference is representative of small business owners as a whole, then programs designed for this group need to be client-centered, problem-solving application activities. Instructors will be looked to as experts for specific assistance in solving particular problems, rather than as scholars discussing abstract principles.

\section{Implications for the study}

Based on the findings discussed in this section, the following assumptions regarding clackamas center clients were investigated by the study:

1) Clients would want to be involved in their own assessment process.

2) Clients would want to be actively involved in the planning, coordinating, and evaluation of their own educational experience. 
3) Clients would be seeking assistance to solve very specific personal and/or business related goals or problems.

4) Clients would want very specific and practical information from a perceived expert, rather than to learn abstract principles from a scholar.

\section{SMALL BUSINESS DEVELOPMENT CENTER PROGRAM HISTORY SECTION}

The national Small Business Development Center (SBDC) program is a nationwide collective group of partnerships between the federal government, individual state governments, state university and/or college systems, and local public and private economic development agencies. The SBDC was established as an eight state pilot project by the U.S. Small Business Administration (SBA) in 1977 (Chrisman, 1985, p. 1). The cooperative model used for this pilot project was the Department of Agriculture/local land grant college cooperative which provides agricultural extension programs designed to meet the needs of local, individual farmers (Bramblett \& Flewellen, 1978, p. 23). This cooperative SBA model served as the basis for the Small Business Development Center Act of 1980 (Title II of PL $96-302)$.

Under the provisions of Title II the SBA was to provide matching funds on a dollar-for-dollar basis of up to $50 \%$ of the cost of developing and operating the program. Each SBDC 
program was to receive a prorated share of the $\$ 65$ million federal allotment for 1980 , based on the ratio of the population they served to the total U.S. population or $\$ 200,000$, whichever was greater (Title II of PL 96-302). By the end of 1988 , with a budget of $\$ 35$ million, the SBDC program had expanded to forty-five states, the District of Columbia, Puerto Rico, and the Virgin Islands (Church, 1987, p. D9; U.S. Small Business Administration, 1989). Only California, Hawaii, Maryland, New Mexico, and Virginia are not a part of the SBDC program.

Each SBDC program is individualized and tailored to meet the specialized economic development needs of small businesses in particular localities. A unique feature of the SBDC partnership is that the state college and/or university system plays a leading role in the administration and coordination of the program. The federal and state governments play primarily a support role within the partnership. Congress noted when establishing the SBDC program that the local academic community would more likely be aware of local needs and problems and be in a better position than the federal government to recommend specific technology, information, and skills to meet those needs (Title II of P.L. 96-302, 1980).

Thus the day-to-day operations, administration, and coordination of the individual SBDC programs is done within each state by a local agency that is affiliated with the 
public four-year college/university system, two-year community college system, or a combination of both systems depending upon the educational and economic development strengths and history of the particular state. The federal government and state governments primarily play a supporting role through providing funding, support personnel, and other resources to supplement and assist the SBDCs in carrying out their economic development mission in a particular area. The resources of the federal government are channeled through the appropriate regional district office of the U.S. Small Business Administration (SBA) within which the SBDC resides (U. S. Small Business Administration, 1989). The designated amount of funds provided by the SBA is specified within an annually negotiated cooperative agreement (M. Mowery, personal communication, July 10, 1989).

The establishment of the SBDC program was intended to increase the competitiveness of the overall U.S. economy through insuring that new and existing small businesses have access to the same quality of advice, information, and services that are available to larger corporations because of their greater resources (Title II of PL 96-302, 1980). The SBDC program provides assistance in solving problems related to operations, marketing, finance, planning, and technology development. This assistance includes, but is not limited to, employee training, owner counseling and educational courses and workshops, and research services for 
small businesses throughout their state. Most of the SBDC programs also work very closely with local and statewide public and private economic and community development agencies in coordinating the economic assistance within their respective states (M. Mowery, personal communication, July 10, 1989).

Each statewide SBDC program is comprised of a network of local centers that provide small businesses with one-to-one counseling, develop educational programs specifically designed for local economic conditions and particular industry needs, and coordinate and conduct research related to the general and technical problems of small businesses within their state (H. Bergmann, personal communication, February 11, 1987). Local SBDC centers seek to employ counselors who have prior experience as small business owners or who have been business executives with extensive business experience (M. Mowery, personal communication, July 10, 1989). Thus counselors have practical business knowledge and experience and are able to provide competent management and technical services in such areas as new venture analysis, business plan development, market planning, and cash flow analysis (H. Bergmann, personal communication, July 14, 1987). 
History of the oregon Small Business

Development Center Network

The history of the Oregon Small Business Development Center Network (OSBDCN) dates from June 1983, when oregon Representative Bill Bradbury (Democrat from Coos Bay) contacted Roger Bassett, Director of the oregon Community College Association, regarding the development of a program that would involve the community college system in assisting small businesses within the state (OSBDCN, 1989). A task force was formed to study the matter and subsequently recommended the adoption of the Business Assistance Center (BAC) program that had been established at Lane community College (Eugene, Oregon) in September 1982 as the model for such a program. The BAC center program provided local small businesses with counseling, long-term educational programs, seminars, and workshops (Cutler, 1984). The BAC center had also worked very closely with local public and private organizations to help coordinate economic development projects in Lane county.

In July 1983, Bill 3002 was passed by the Oregon Legislature which provided $\$ 500,000$ for the 1983-1985 biennium to develop a statewide community college network of centers based on the Lane Community college model (Cutler, 1984). The next step in the process was the appointment of a state Advisory Council by the state Superintendent of Public Instruction. The community college system comes under the auspices of Oregon Department of Education. In 
December 1983, the advisory council subsequently recommended that the state should submit a proposal to the SBA for the development of a Small Business Development Center program. In February 1984, the SBA signed a cooperative agreement with Lane Community college for $\$ 350,000$ to establish a statewide SBDC program. On the recommendation of the state Advisory Council, the Network headquarters or "control center" was established at Lane Community college (Cutler, 1984). OSBDCN had the distinction of being the first community college based SBDC program in the nation (Belcher, personal communication, February 14, 1989). In september 1984, OSBDCN consisted of 15 community colleges, Southern Oregon State College, and Eastern Oregon state College. In June 1987, responsibility for the OSBDCN was moved from the Oregon Department of Education to the Oregon Economic Development Department (OSBDCN, 1989).

In 1988 , with a budget of $\$ 2,994,314$, OSBDCN consisted of 22 individual centers across the state. The funding sources for the 1988 budget are presented in Table V. During 1988, OSBDCN provided counseling for 6,371 individuals, which was an increase of $12 \%$ over 1987 (p. 4). A total number of 923 training activities, in the form of specialized classes, workshops, and seminars, were conducted in 1988 which was an $11 \%$ increase over 1987. The resources of the centers were utilized by 15,126 individuals during 1988, which was a slight decrease (5\%) for 1987 (p. 5). 
TABLE V

OREGON SMALL BUSINESS DEVELOPMENT CENTER NETWORK BUDGET 1988

\begin{tabular}{lcc}
\hline Funding Source & Dollar Amount & Percentage of Total \\
\hline Federal Funding & $\$ 741,000$ & $25 \%$ \\
State Funding & 475,000 & $16 \%$ \\
Local Funding & $1,778,314(1)$ & $59 \%$ \\
Total & $\$ 2,994,314$ & $100 \%$ \\
\hline
\end{tabular}

(1) Educational institutions, private organizations, etc. Note. Adapted from 1988 Annual Report (p. 7) by oregon Small Business Development Center Network, 1988, Salem, OR: Oregon state Printing office.

Since its beginning in 1984, OSBDCN (through 1988) has provided 23,651 individuals with specialized counseling and has conducted 3,646 training activities that have been attended by a total of 71,189 individuals (p. 8).

History of the Clackamas Small Business Development Center

The Clackamas Center is located in the clackamas Community College Harmony Center, 7616 S.E. Harmony Road, Milwaukie, oregon. The center opened its doors to the public in August 1984. The center began as a partnership between Clackamas Community College, Clackamas Business Promotion Company, clackamas county, county chambers of commerce, the state of oregon, and the U.S. Small Business Administration (1985). During 1985, 378 clients received assistance from the center (Clackamas Center, 1985, p. 7). 
During 1988, the number of clients receiving assistance increased to 458 , with 105 clients successfully completing the center's Small Business Management Programs (OSBDCN, p. 10). This makes clackamas center's program the third largest in the OSBDCN after Portland Community college, and Lane Community College (OSBDCN, 1988, p. 4).

The Clackamas Center's Small Business Management program consists of three integrated programs: the Greenhouse, Small Business Management I, and Small Business Management II programs. The Greenhouse program is designed to assist the individual in conducting a feasibility study of a new business idea. The Small Business Management I program is for the business owner who needs to learn basic financial management techniques. The Small Business Management II program focuses on advanced financial management and marketing management techniques.

\section{CONCLUSION}

Prior studies of the Small Business Development Center Program have primarily defined effectiveness in terms of a financial cost/benefit analysis. The estimated tax revenue generated by center clients has been compared to the costs of funding the program. If tax revenues are greater than costs, then the programs have been espoused as being worthy of continued funding. A case could be made that funding such a program is an effective use of funds. However, by 
measuring the benefits only in terms of costs, the question of whether there might be more effective ways to use funds to assist small businesses is left unanswered.

The current study attempts to broaden the understanding of who utilizes the services of the SBDC, and the appropriateness of both the assistance given to clients and the way in which it was given. The small business growth literature was used as a basis for analyzing the appropriateness of the information given to clients. The adult learning literature was used as a basis for analyzing the procedures, processes, and factors that were used by the SBDC to transfer that information. 
CHAPTER III

METHODS

The following study was designed to accomplish three overall research objectives. The first objective was to find out who the clients were that sought assistance from the Clackamas Small Business Development Center (Clackamas Center) and how they rated the center's short-term Counseling, and Greenhouse/Small Business Management (SBM) Programs. The second objective was to find out what factors, procedures, and processes were actually used by Center personnel in the design and delivery of the Short-term Counseling and SBM programs. The third objective was to evaluate the informational, instructional, and curricular design of the SBM programs from the prospective of the small business growth model and adult learner literature.

In order to achieve these three overall research objectives, the evaluation study was implemented in two phases. Phase I was a survey of the 488 clients that utilized the Short-term Counseling and/or SBM programs during 1989. Phase II consisted of interviewing and obtaining materials from the Clackamas Center personnel involved in these programs. The interview responses and 
program materials that were obtained during phase II were then compared to program attributes suggested by the small business growth and adult learning literatures.

The remainder of this chapter will discuss the following subjects for each phase of the study: the broad research objectives, research design, instruments, data collection procedures, and the analysis of the data to be collected.

PHASE I: CLIENT SURVEY

\section{Research Objectives}

The following were the five major objectives to be accomplished during the first phase of the evaluation study:

1) Develop a demographic profile of the clients who used the Center's Short-term Counseling and SBM programs during 1989.

2) Measure client satisfaction with the informational content of the Short-term counseling and SBM programs.

3) Measure client satisfaction with the instructional and curricular design of the SBM program.

4) Ascertain what clients perceived to be the benefits of participating in the short-term counseling and SBM programs.

5) Test whether clients at different growth stages would significantly differ in their evaluation of informational content of the SBM program. 
Research Design

Phase I of this study was developed in collaboration and cooperation with the director of the clackamas center. A preliminary investigation by the researcher revealed that the center was in the final phases of complying with a research related directive from the oregon Small Business Development center Network office (OSBDCN). OSBDCN had requested each individual center to develop a survey and ascertain client satisfaction with their Short-term Counseling program. The Clackamas Center had developed a questionnaire and a mailing list consisting of the 488 clients who had used the short-term counseling services during 1989. The center director agreed to expand the focus of the questionnaire to include the research objectives of this study and provide the financial and personnel resources to print, mail, and administer the survey (see copy of questionnaire in Appendix A) .

The survey instrument was reviewed and developed in collaboration with personnel at both the clackamas center and the Portland Community college Small Business Development center (PCC Center). At the clackamas Center the director and all eight short-term Counselors and SBM Instructors individually reviewed the initial questionnaire and were instrumental in suggesting appropriate "number of employees," "dollar amount of assets," and "annual sales volume," demographic categories that were used in the final 
survey instrument. The client survey was test piloted on-site at the PCC center. The PCC center director and one SBM instructor completed the client survey. Follow-up evaluation interviews were conducted with both individuals. Each interview lasted approximately 30 minutes. The questions were judged by the interviewees as being appropriate and non-biasing in nature. Thus no changes were made in the survey instrument.

\section{Questionnaire Design}

The following discussion describes the construction of key dependent and independent variables that were utilized for both descriptive and hypothesis testing purposes.

\section{Key Dependent Variables}

The key dependent variables that were utilized in measuring client satisfaction with the Short-term counseling and SBM programs were contained within question 10 (see Appendix A) . Question 10 was segmented into three sections: a Counseling section, a SBM program section, and an overall Center evaluation section. Only the counseling and SBM program sections were used in this evaluative study. These two program sections were comprised of a series of statements; each statement represented one aspect of either the information content or delivery design of the respective program. The respondent was requested to designate on a five point interval scale the degree to which he/she agreed 
or disagreed with the statement. The Key Dependent

Variables used in the study are listed below. Each variable name is underlined, followed by the appropriate definition for that variable.

counseling section

Counselor's Knowledge. The counselor's knowledge of problem(s) to be addressed was excellent. Counselor's Suggestions. The counselor's suggestions to solve the problem(s) being discussed were appropriate for the situation.

Counselor's Promptness. Your request for assistance received prompt attention by the counselor.

Counselor's courteousness. The counselor was courteous towards you.

Counselor's Understanding. The counselor understood your long-term goals for your company. Materials Provided. The materials provided to you by the counselor were excellent.

Greenhouse/Small Business

Management Section

Appropriate Information. The information presented in the SBM classes was appropriate for the needs of your company.

Instructor's Knowledge. The instructor's knowledge of the subject area was excellent. 
Client Participation. Your participation in planning, coordinating, and tailoring the subject matter of the classes to the specific needs of your company was sufficient and appropriate.

Counseling portion. The counseling portion of the SBM program is appropriate.

class Ratio. The ratio of class hours to counseling hours is appropriate.

Counseling Hours. The counseling hours should be expanded to a twice a month schedule.

Instructional Methods Effectiveness. The instructional methods (lecture, video, computer simulation, etc.) are effective in assisting your understanding of the material. Variety of Instructional Methods. There is a sufficient variety of instructional methods utilized in the classes (lecture, video, computer simulation, etc.).

\section{Key Descriptive Independent Variables}

The key descriptive independent variables that were developed are the preferred instructional style and the small business growth stage.

\section{Preferred Instructional styles}

These independent demographic variables were related to question 13 of the client survey. Question 13 contained seven sub-questions which were adapted from wheller and Marshall's (1986) Training Style Preferences Inventory. 
This inventory was developed to assist trainers to identify the instructional methods and delivery style they tend to utilize in a classroom situation. Wheller and Marshall suggest that learners prefer different instructional styles and methods, depending on their own preferred learning style (Concrete Experiencers, Reflective Observers, Abstract Conceptualizers, and Active Experimenters). The respondent was requested to distribute ten points between the four options of each question, with each option representing one of the four instructional styles (Listener, Director, Interpreter, and (oach). For the purposes of this study, each sub-question was treated as a separate demographic variable, representing another aspect of the client's preferred instructional style.

As a part of the interview process in Phase II of the study, the instructor/counselors were asked to complete a corresponding Instructor Type Inventory so that comparisons could be made between client and instructor responses (see Appendix B) .

\section{Small Business Growth Stage}

The specific growth stage of clients was developed utilizing both the number of employees employed by the company (question 17) and the dollar amount of organizational assets (question 18). The two methods may categorize specific clients into different growth stages because of the ability of firms to increase the level of 
assets without comparable increases in employees.

Steinmetz's (1969) measurement criteria was utilized in

categorizing clients ( $p .31$ ) (see Table VI).

TABLE VI

THE SMALI BUSINESS GROWTH STAGE

SEGMENTED BY CATEGORIES

1990

\begin{tabular}{|c|c|c|}
\hline \multicolumn{3}{|c|}{ Number of Employees Categories (Question 17) } \\
\hline $\begin{array}{l}1 . \\
2 .\end{array}$ & $\begin{array}{l}\text { Pre-stage one Company } \\
\text { Stage one Company }\end{array}$ & $\begin{array}{l}\text { "Haven't started the company" } \\
\text { "Only Owner" }\end{array}$ \\
\hline 3 . & Stage Two Company & "1-5","6-10", "11-24" \\
\hline 4. & $\begin{array}{l}\text { Stage Three Company } \\
\text { Dollar Amount of Assets }\end{array}$ & $\begin{array}{l}\text { "25 employees and above" } \\
\text { Categories (Question 18) }\end{array}$ \\
\hline $\begin{array}{l}1 . \\
2 .\end{array}$ & $\begin{array}{l}\text { Pre-Stage One Company } \\
\text { Stage one Company }\end{array}$ & $\begin{array}{l}\text { "Haven't started the company" } \\
\text { "Start-up capital/assets only" }\end{array}$ \\
\hline 3. & Stage Two Company & $\begin{array}{l}\text { "Less than } \$ 100,000 " ; \text { and } \\
\text { "From } \$ 100,000 \text { up to } \$ 500,000 "\end{array}$ \\
\hline 4. & Stage Three Company & $\begin{array}{l}\text { "From } \$ 500,000 \text { up to } \$ 1 \\
\text { million"; \& "Over } \$ 1 \text { million" }\end{array}$ \\
\hline
\end{tabular}

Data Collection Procedures

To insure client confidentiality and anonymity during the study, the following administrative process was followed. A mailing list containing the names and addresses of all clients (488) that sought assistance during 1989 was compiled by Clackamas center personnel. Client names were 
consecutively numbered, and this number was placed in the left hand corner of the self-addressed return envelope included with the questionnaire. Clackamas center personnel were in charge of administering the questionnaire mailing process. The initial mailing took place March 19, 1990. Upon receiving the self-addressed return envelopes, center personnel opened the envelopes, removed the questionnaires without reading the contents, destroyed the return envelopes, and placed a check mark by the name of the subject on the mailing list to signify the return of the survey. The questionnaires were systematically obtained from the center and computer processed utilizing the SYSTAT, version 4.1 , statistical program. The questionnaires were numbered upon being processed, but no attempt was made to identify respondents with their individual surveys at any time during the study. From the original mailing to 488 clients, a response rate of 14.5 percent (71 respondents) was achieved. A second mailing was made April 20, to 417 non-respondents. Utilizing two mailings, a response rate of 29.5\% (144 respondents) was achieved.

\section{Data Analysis}

The SYSTAT, version 4.1 , statistical program was utilized to calculate the appropriate frequency distributions, cross-tabulations, and statistical significance tests. Selected frequency distributions and cross-tabulations were utilized to develop a client profile 
and selected frequency tables. Because the scale utilized to measure the key dependent variables in client survey question 10 (Highly Agree $\begin{array}{llllllll}5 & 4 & 3 & 2 & 1 \\ \text { Highly Disagree) was }\end{array}$ appropriate for generating interval level data, means and standard deviations were used to measure client satisfaction levels (Alreck and Settle, 1985, p. 146; J. Arick, personal communication, July 5, 1990). One-way Anovas, Tukey-Cramer multiple comparison methods, and Analysis of Covariance tests were utilized for Hypotheses testing.

Hypotheses were developed to test whether clients at different growth stages would significantly differ in their evaluation of the informational content of the center's counseling and SBM programs. If the Small Business Growth Stage Model was representative of the needs of oregon Small Businesses, then one could expect clients to become less satisfied with the informational content of a basic assistance program as they moved from pre-stage one to a stage three company. The following hypotheses were tested at the .05 significance level:

Hypothesis one: A significant difference exists between clients of differing small business growth stages (pre-starting stage, stage one, stage two, stage three) in their evaluation of the counselor's knowledge of the specific problem area (Counselor's Knowledge). 
Hypothesis Two: A significant difference exists between clients of differing small business growth stages (pre-starting stage, stage one, stage two, stage three) in their evaluation of the appropriateness of the counselor's suggestions for the specific situation (Counselor's Suggestion). Hypothesis Three: A significant difference exists between clients of differing small business growth stages (pre-starting stage, stage one, stage two, stage three) in their evaluation of the counselor's understanding of their long-term company goals (Counselor's Understanding). Hypothesis Four: A significant difference exists between clients of differing small business growth stages (pre-starting stage, stage one, stage two, stage three) in their evaluation of the materials provided by the counselor (Materials Provided). Hypothesis Five: A significant difference exists between clients of differing small business growth stages (pre-starting stage, stage one, stage two, stage three) in their evaluation of the appropriateness of the information presented in the small business management classes for their company's needs (Appropriate Information). Hypothesis Six: A significant difference exists between clients of differing small business growth 
stages (pre-starting stage, stage one, stage two, stage three) in their evaluation of the instructor's knowledge of the subject area (Instructor's Knowledge).

Hypothesis Seven: A significant difference exists between clients of differing small business growth stages (pre-starting stage, stage one, stage two, stage three) in their evaluation of whether the counseling portion of small business management program vas appropriate (Counseling Portion).

Prior to conducting any statistical analysis, three statistical procedures, the Cronbach Coefficient Alpha Test, the Spearman-Brown Coefficient (split-half reliability test), and Factor Analysis were conducted in order to test the integrity of the key dependent variable that would be used in measuring client satisfaction and hypotheses testing. These were important tests in analyzing the reliability of the survey instrument. The Cronbach coefficient Alpha test was used to confirm the reliability (internal consistency) of each dependent variable within each Center assistance program. In other words, the Cronbach Coefficient Alpha test indicates the degree to which the dependent variables which comprise each assistance program are interrelated. The Spearman-Brown coefficient procedure was used to test the overall internal consistency 
of all dependent variables taken together in each center assistance program. Tables VII and VIII present a comparison between the results of the Cronbach Alpha Test and the Spearman-Brown Coefficient test for the counseling and SBM variables respectively.

TABLE VII

RELIABILITY SCORES OF KEY COUNSELING PROGRAM DEPENDENT VARIABLES 1991

\begin{tabular}{lll}
\hline $\begin{array}{l}\text { Key Dependent } \\
\text { Variable }\end{array}$ & Cronbach Alpha & $\begin{array}{l}\text { Spearman-Brown } \\
\text { Coefficient }=.885\end{array}$ \\
\hline $\begin{array}{l}\text { Counselor's } \\
\text { Knowledge }\end{array}$ & .800 \\
$\begin{array}{l}\text { Counselor's } \\
\text { Suggestions }\end{array}$ & \\
$\begin{array}{l}\text { Counselor's } \\
\text { Promptness } \\
\text { Counselor's } \\
\text { Courteousness }\end{array}$ & .796 \\
$\begin{array}{l}\text { Counselor's } \\
\text { Understanding }\end{array}$ & .842 \\
$\begin{array}{l}\text { Materials } \\
\text { Provided }\end{array}$ & .860 \\
\hline
\end{tabular}


TABLE VIII

RELIABILITY SCORES OF KEY SMALL BUSINESS MANAGEMENT PROGRAM DEPENDENT VARIABLES 1990

\begin{tabular}{|c|c|c|}
\hline $\begin{array}{l}\text { Key Dependent } \\
\text { Variable }\end{array}$ & Cronbach Alpha & $\begin{array}{l}\text { Spearman-Brown } \\
\text { Coefficient }=.880\end{array}$ \\
\hline Appropriate & & \\
\hline Information & .843 & \\
\hline $\begin{array}{l}\text { Instructor's } \\
\text { Knowledge }\end{array}$ & .846 & \\
\hline $\begin{array}{l}\text { Client } \\
\text { Participation }\end{array}$ & .838 & \\
\hline $\begin{array}{l}\text { Counseling } \\
\text { Portion }\end{array}$ & .855 & \\
\hline Class Ratio & .834 & \\
\hline Counseling Hours & .866 & \\
\hline $\begin{array}{l}\text { Instructional } \\
\text { Methods } \\
\text { Effectiveness }\end{array}$ & .820 & \\
\hline $\begin{array}{l}\text { Variety of } \\
\text { Instructional } \\
\text { Methods }\end{array}$ & .839 & \\
\hline
\end{tabular}

The Spearman-Brown Coefficients of .885 and .880 are well within the $.85-.90$ acceptable level of reliability range suggested by Brown (1983, p. 89). The Cronbach Alpha scores show what the Spearman-Brown Coefficient would be if this variable was subtracted from the statistical procedure. The high spearman-Brown coefficients in conjunction with the Cronbach Alpha scores that were obtained, suggest that the 
key dependent variables within each Center assistance program are reliable in measuring client satisfaction.

A factor analysis was conducted for both programs in order to test for the existence of more than one concept within each group of variables. The factor analysis for the Counseling variables showed the existence of only one factor. The factor analysis for the SBM programs (Eigen value $=1$ ) showed the existence of two factors: Instructional Factor: Appropriate Information, Instructor's knowledge, Variety of Instructional Methods, client Participation, Instructional Methods Effectiveness (39 percent of the variance explained by this factor). Long-term Counseling Factor: Ciass Ratio, Counseling Hours, Counseling Portion ( 31.5 percent of the variance explained by this factor).

The existence of only one factor for the counseling program and the particular factors (instructional, counseling) that were developed for the SBM program increase the likelihood that the variables do in fact measure client program satisfaction. The result of the Phase I data analysis is presented in chapter four.

\section{PHASE II: CLACKAMAS CENTER PERSONNEL INTERVIEWS}

During phase II of the evaluation study, a series of in-depth interviews was conducted with the clackamas center personnel involved in both the Short-term Counseling and 
Greenhouse/Small Business Management program. One focus of this phase was to ascertain what processes, procedures, and systems, center personnel utilized in assisting clients. Another focus was to ascertain what factors were utilized by center personnel in developing the assistance that was offered to specific clients. A third focus was to ascertain how clients were involved in the planning, coordinating, and delivery of the assistance they received at the center.

\section{$\underline{\text { Research Design }}$}

The first step in phase II was to assemble criteria that would be used in developing the interview instrument, analyze interview responses, and evaluate program content and instructional design of the Greenhouse and Small Business Management programs. The small business growth stage and adult learning literatures were used in developing a "Small Business Information Content and Instructional Design Program Checklist" (see Appendix C). The checklist was designed to achieve three specific objectives. The first objective was to develop an instrument based on the research findings discussed in chapter two that could be used to evaluate the informational content and instructional design of the Clackamas Center's Greenhouse and Small Business Management programs. The second objective was to develop an instrument so that other oregon SBDCs could evaluate the informational content and instructional design of their own Small Business Management programs. The third 
objective was to develop an instrument that could also be used by SBDC program developers to evaluate future assistance programs designed for small business.

The informational content section of the checklist is divided into two sub-sections. The first sub-section contains the criteria which research suggests is needed to complete a comprehensive feasibility study. This subsection was utilized in analyzing the Greenhouse Program. The second sub-section contains informational areas which research suggests are pertinent to on-going businesses. This sub-section was utilized in analyzing the Small Business Management Programs. The instructional design section of the checklist is comprised of instructional and student involvement methods which research suggests are especially effective with adult learners. This section of the checklist was used to evaluate both the Greenhouse and Small Business Management programs (see Appendix C).

Personnel Interview Questionnaire Development

The "Small Business Information content and Instructional Design Program Checklist" was utilized in developing the Personnel Interview Questionnaire. The questions were designed to ascertain the factors, processes, and procedures utilized by center personnel in assisting clients. Instructor/counselors were asked about their instructional methods, the ways in which they involve 
clients in designing the educational process, and whether the size of the company influenced the assistance given to clients (see Appendix B).

The questionnaire was test piloted on-site at the Portland Community College Small Business Development Center (see Appendix B). Two interviews were conducted between June $6-7,1990$ with center personnel involved in the short-term counseling and small business management programs. Each interview lasted approximately one and one half hours, including a short follow-up evaluation of the instrument. The questions were judged by the interviewees as being appropriate and non-biasing in nature. Thus no changes were made in the interview instrument.

\section{Data collection}

The actual series of in-depth interviews were conducted on-site, at the Clackamas center between June $10-13,1990$. The interview with each of the five short-term counselors lasted approximately one hour. Each interview with the three Greenhouse/Small Business Management program instructor/counselors lasted approximately one and one half hours.

The interview protocol for the researcher was to introduce himself, explain briefly the purpose of the interview, and conduct the interview using the "Personnel Interview Questionnaire." Permission was received from each person interviewed to utilize a tape recorder during the 
interview sessions. Each person interviewed was assured by the researcher that all responses would remain confidential and anonymity would be maintained in the reporting process. At the end of interview sessions, copies of handouts and other materials were collected for further analysis.

\section{Analysis of Data}

In order to maintain the confidentiality of the individuals interviewed, individual responses were consolidated into an overall center analysis. The "Small Business Information Content and Instructional Design Program Checklist" was used in analyzing center personnel responses. The checklist was used to compare the actual factors, processes, and procedures that center personnel used in the informational and instructional design of the Greenhouse and SBM programs with those recommended by the small business growth and adult learning literatures. The informational content section of the checklist was utilized in analyzing the Greenhouse and Small Business Management course materials obtained at the time of the center personnel interviews. 
CHAPTER IV

\section{ANALYSIS AND DISCUSSION}

The following analysis is of major study findings related to the clackamas Center's Short-term Counseling and Greenhouse/Small Business Management (SBM) programs. The topics to be discussed are the client survey response rate, client profile, informational content, and instructional design of the assistance programs, and the client-perceived benefits of the assistance. A complete summary of the client survey, and center personnel interviews can be found in Appendix $D$ and $H$, respectively.

\section{CLIENT SURVEY RESPONSE RATE}

A 29.5 percent response (144 respondents) was obtained from all clients receiving assistance from the clackamas Center during 1989. Of these 144 respondents, 76 clients (53.2 percent) had participated in both the Short-term counseling and SBM programs, and 67 clients (46.8 percent) had only participated in the short-term counseling program. The low response rate limits the degree to which the study's finding can be generalized to the total clientele of both the oregon Network (OSBDCN) and the Clackamas center. 
Low response rates appear to be a common problem for SBDC related studies (see Table IX).

TABLE IX

PRIOR SMALL BUSINESS DEVELOPMENT CENTER STUDIES 1990

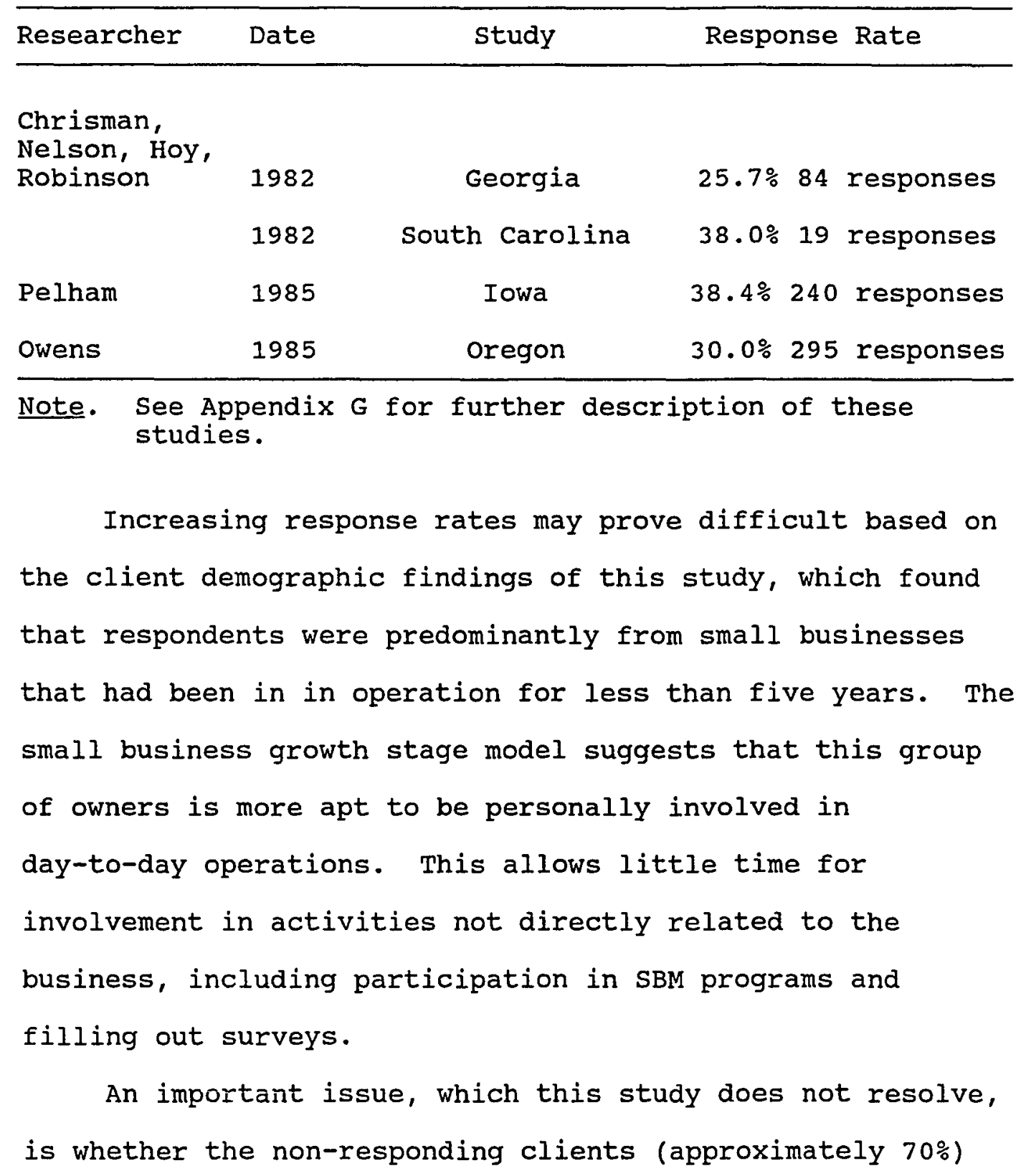


differ markedly from respondents in their demographic profile and level of program satisfaction. The clackamas center personnel felt that the demographic profile was indeed representative of their clientele. Although the study findings may be limited in generalizability, they do provide important information regarding a significant segment (approximately $30 \%$ ) of the clackamas Center's clientele.

\section{CLIENT PROFILE}

The majority of the respondents $(78.3 \% ; 112$

respondents) were owners or managers of already existing businesses. They tend to be from relatively young companies. Approximately 65 percent of the respondents had been in business for less than five years. This compares to an Oregon Economic Development Department's estimate that only 22 percent of all Oregon businesses with less than 50 employees have been in business for less than 5 years (see Table $\mathrm{X}$ ) . 
TABLE $X$

NUMBER OF YEARS IN OPERATIONS 1990

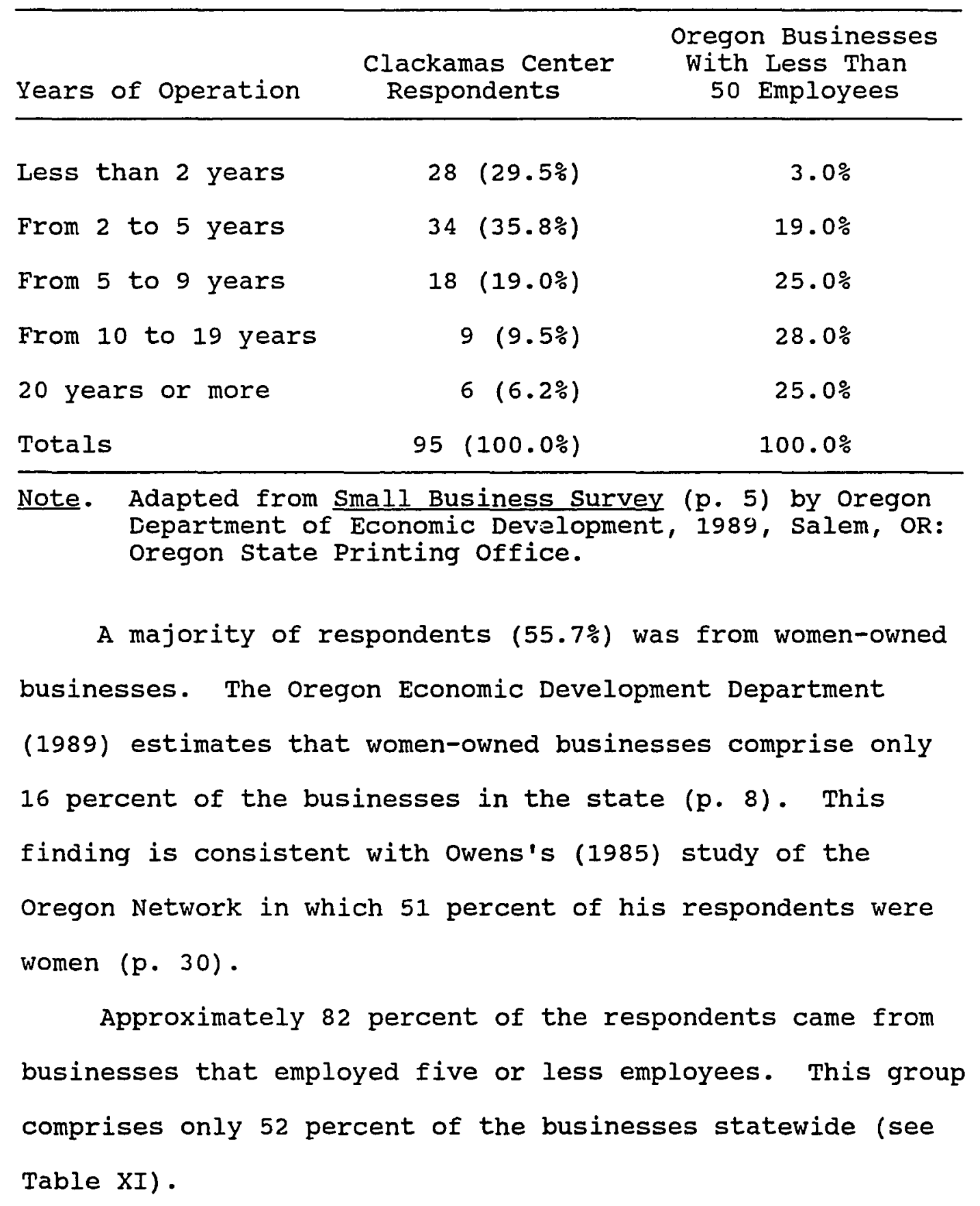


TABLE XI

\section{PERCENTAGE OF ALL BUSINESSES \\ BY NUMBER OF EMPLOYEES \\ 1990}

\begin{tabular}{lcrlr}
\hline \multicolumn{2}{c}{$\begin{array}{c}\text { Clackamas Center } \\
\text { Respondents }\end{array}$} & \multicolumn{2}{c}{$\begin{array}{c}\text { Oregon Businesses } \\
\text { With Less Than } \\
50 \text { Employees }\end{array}$} \\
\hline $1-5$ & 94 & $82.5 \%$ & Less than 5 & $52 \%$ \\
$6-10$ & 6 & $5.3 \%$ & $5-9$ & $23 \%$ \\
$11-24$ & 7 & $6.1 \%$ & $10-19$ & $15 \%$ \\
$25+$ & 7 & $6.1 \%$ & $20-49$ & $10 \%$ \\
Totals & 114 & $100.0 \%$ & & \\
\hline
\end{tabular}

Note. Adapted from Small Business Survey (p. 6) by oregon Department of Economic Development, 1989, Salem, OR: oregon state Printing office.

Utilizing the small business growth model "number of employees" criteria to categorize respondents, the study found that 77 percent of the clients were stage one and stage two companies (see Table XII). The "dollar amount of assets" criteria appears to shift approximately 12 percent of the stage one clients to stage two. Two factors that may account for this shift are time lags between increasing sales and hiring employees, or increasing sales without any plans for hiring more employees.

Most respondents $(81.6 \%)$ were from service related companies. This compares to 83 percent in Owens's Network study (see Table XIII). 
TABLE XII

RESPONDENTS BY SMALL BUSINESS GROWTH STAGE 1990

\begin{tabular}{lrrrr}
\hline & $\begin{array}{l}\text { Number of Employees } \\
\text { Clients }\end{array}$ & Percent & Dollar Amount Of Assets \\
\hline & 25 & 18.0 & 25 & 18.3 \\
Pre-stage one & 25 Percent \\
Stage one & 56 & 40.3 & 36 & 26.3 \\
Stage Two & 51 & 36.7 & 67 & 48.8 \\
Stage Three & 7 & 5.0 & 9 & 6.6 \\
Total & 139 & 100.0 & 137 & 100.0 \\
\hline
\end{tabular}

TABLE XIII

RESPONDENTS BY INDUSTRY 1990

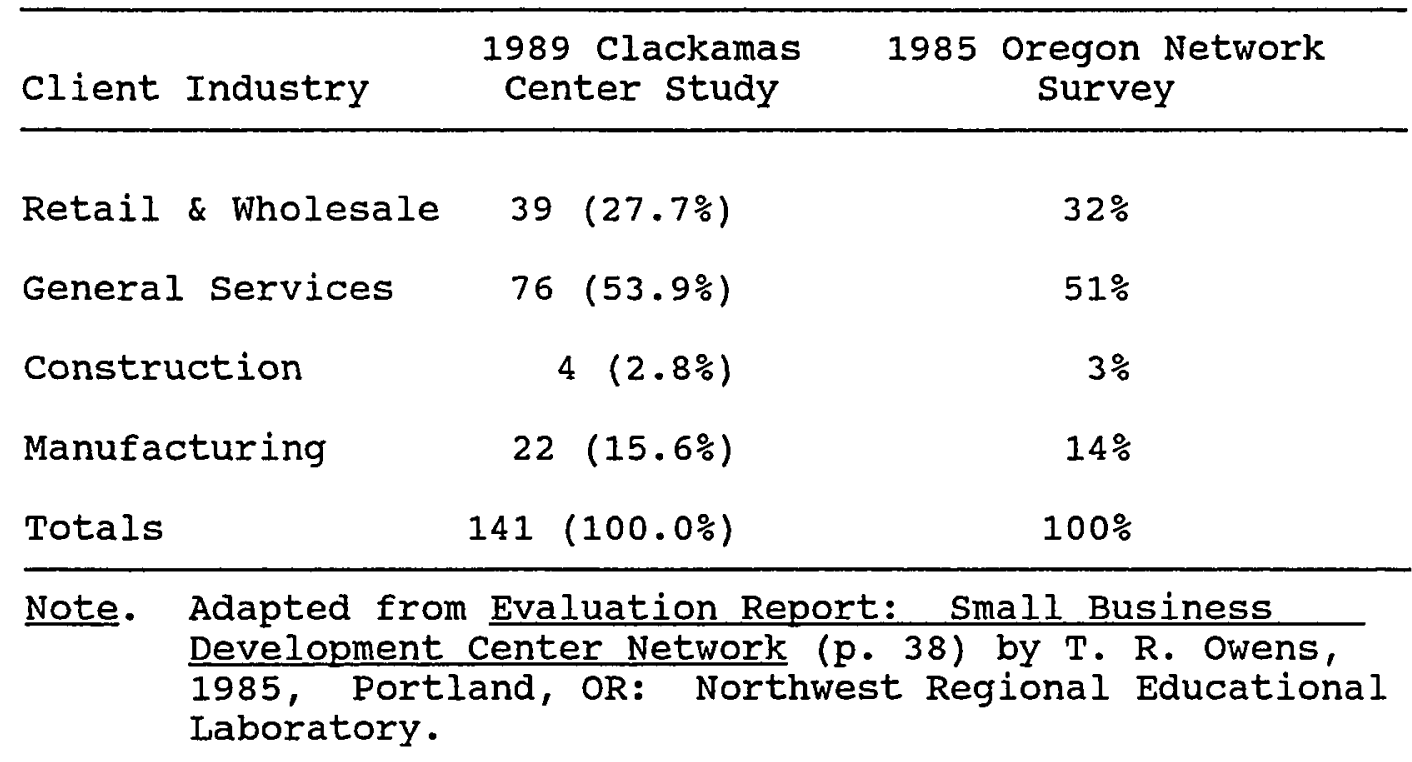

Approximately 72 percent of the respondents were are between 30 and 49 years of age (see Table XIV). 
TABLE XIV

RESPONDENTS BY AGE 1990

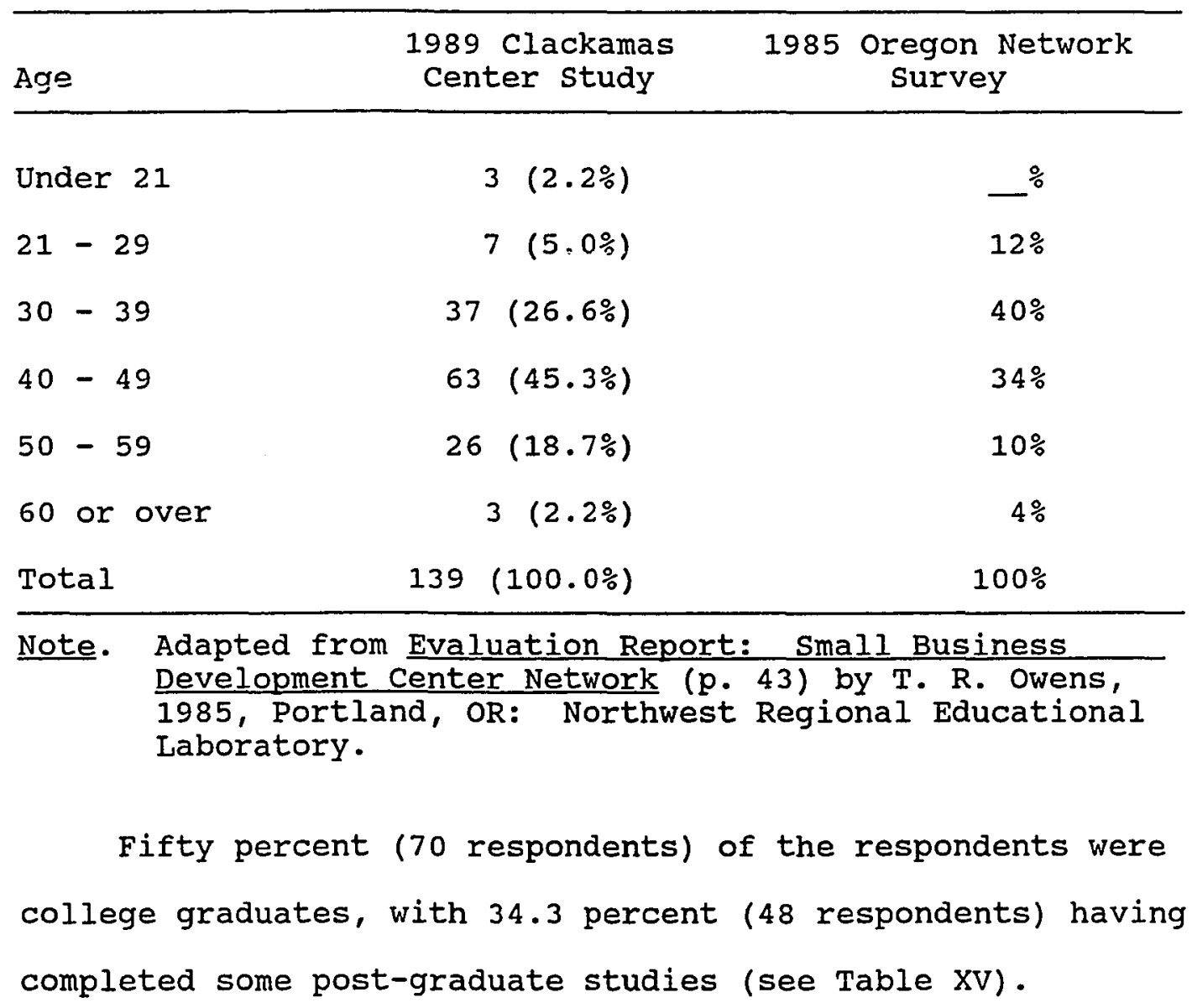


TABLE XV

EDUCATIONAL BACKGROUND OF RESPONDENTS 1990

\begin{tabular}{lc}
\hline Educational Background & Number of clients \\
\hline High school or less & $17(12.1 \%)$ \\
Some college & $53(37.9 \%)$ \\
College graduate & $22(15.7 \%)$ \\
Some post-graduate work & $27(19.3 \%)$ \\
Post-graduate degree & $21(15.0 \%)$ \\
Total & $140(100.0 \%)$ \\
\hline
\end{tabular}

Approximately 81 percent (114 respondents) of the respondents said they wanted assistance is solving specific business programs when they visited the center (see Table XVI) .

Summary of Client Profile Findings

The study found that the typical respondents were from companies that had been in operation for a relatively short period of time, employed few people, and were in the service industry. Owners tended to be middle aged, highly educated, and interested in solving specific business problems when seeking assistance. Most clients were found to be either stage one or stage two clients. 
TABLE XVI

SPECIFIC PROBLEM AREAS FOR WHICH

RESPONDENTS SOUGHT ASSISTANCE 1990

\begin{tabular}{lc}
\hline Problem Area & Number of clients \\
\hline Marketing & $63(55.3 \%)$ \\
Business Plan Preparation & $57(50.0 \%)$ \\
Accounting/Bookkeeping & $42(36.8 \%)$ \\
Market Analysis & $37(32.5 \%)$ \\
Business Feasibility & $33(29.0 \%)$ \\
Financial Assistance & $28(24.6 \%)$ \\
Management Structure & $19(16.7 \%)$ \\
Legal & $19(16.7 \%)$ \\
Other (non-specified) & $15(13.2 \%)$ \\
Personnel & $14(12.3 \%)$ \\
Production & $8(7.0 \%)$ \\
Inventory Control & $8(7.0 \%)$ \\
Technical Assistance & $8(7.0 \%)$ \\
\hline
\end{tabular}

Note. Percentages are greater than $100.0 \%$ because of clients seeking assistance for multiple problems.

ANALYSIS OF PROGRAM CONTENT

Table XVII presents the client means for both the Short-term Counseling and SBM program informational content variables. 
TABLE XVII

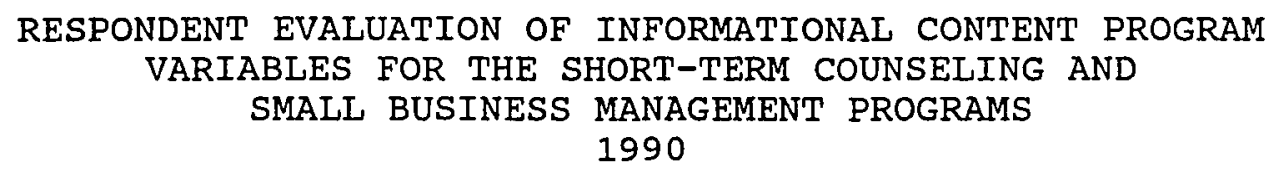

\begin{tabular}{|c|c|c|c|}
\hline Program Variables & $\begin{array}{l}\text { nber of } \\
\text { lients }\end{array}$ & Mean & $\begin{array}{c}\text { Standard } \\
\text { Deviation }\end{array}$ \\
\hline \multicolumn{4}{|c|}{ Short-term Counseling } \\
\hline Counselor's Knowledge & 140 & 4.150 & 0.873 \\
\hline Counselor's Suggestions & 140 & 4.050 & 0.947 \\
\hline Counselor's Understanding & 140 & 4.257 & 0.860 \\
\hline Materials Provided & 134 & 3.970 & 1.018 \\
\hline \multicolumn{4}{|c|}{ Small Business Management } \\
\hline Appropriate Information & 71 & 3.690 & 1.141 \\
\hline Instructor's Knowledge & 73 & 4.123 & 0.942 \\
\hline Counseling Portion & 72 & 4.333 & 0.822 \\
\hline Class Ratio & 70 & 3.886 & 1.057 \\
\hline Counseling Hours & 70 & 3.686 & 1.336 \\
\hline
\end{tabular}

Note. Base upon the following " 5 - 1 " interval scale: Highly Agree $\begin{array}{lllllll}5 & 4 & 2 & 1 \\ \text { Highly Disagree. }\end{array}$

The client mean for the variable "Appropriate Information" lies at the low end of the $3.686-4.333$ range for all nine informational content variables (for both programs). Respondents appear to have been least satisfied with the information presented in the SBM class sessions. Two factors that may have influenced the low client rating of appropriate information are apparent differences in 
client/instructor expectations (see Table XVIII) and the topics covered in the program's curriculum.

Center personnel and clients appear to have opposite expectations of what the SBM program is intended to accomplish. Instructors and counselors understand the primary purpose is to assist clients in learning the skills necessary to solve their own business problems (Appendix $\mathrm{H}$ ). Their goal for the individual completing the SBM programs is for that person to effectively utilize company records, develop solutions to problems, and manage organizational growth. Clients, on the other hand, come to the program expecting practical solutions that can be adopted in their companies.

This dichotomy between the clients and center personnel can be seen in Tables XVIII and XIX, which compare the responses of both groups to questions in the wheeler and Marshall (1986) Training style Preference Inventory (a summary of the test comparisons appears in Appendix F). Table XVIII reveals that clients envision the instructor as an advisor, an expert, an interpreter of information, and a person directly involved in problem solving. Center personnel envision themselves as as advisors, coaches, group facilitators. They prefer a role of helping clients to find their own specific solutions. 
TABLE XVIII

COMPARISON OF RESPONDENTS AND CENTER PERSONNEL PREFERENCES OF INSTRUCTOR'S INSTRUCTIONAL ROLE 1990

\begin{tabular}{lcc}
\hline $\begin{array}{l}\text { Preferred Instructional } \\
\text { Emphasis }\end{array}$ & $\begin{array}{c}\text { Client } \\
\text { Preferences }\end{array}$ & $\begin{array}{c}\text { Center Personnel } \\
\text { Preferences }\end{array}$ \\
\hline
\end{tabular}

$\begin{array}{lll}\text { (Sub-Question 6) } & \mathrm{N}=129 & \mathrm{~N}=8\end{array}$

An Expert

$35.1 \% \quad 21.4 \%$

A Scholar

$11.9 \%$

$2.9 \%$

An Advisor

$37.7 \%$

$58.6 \%$

A Friend

$15.3 \%$

$17.1 \%$

(Sub-Question 7)

$\mathrm{N}=129 \quad \mathrm{~N}=8$

A Coach

$22.2 \%$

$51.5 \%$

A Group Facilitator

$20.3 \%$

$25.7 \%$

A Director

$19.0 \%$

$5.7 \%$

An Interpreter of Information

$38.5 \%$

$17.1 \%$

Note. Respondents were requested to distribute 10 points between all four of the above responses for both sub-question 6 and 7 . The percentages were calculated by using the total number of points for that particular question.

Table XIX reveals that although both groups value the independent application of information and the teaching of theories and principles, client and center personnel place a greater emphasis on the opposite instructional emphasis. Clients emphasize the instructor's role of demonstrating application and instructors emphasize the client's role of self-discovery (independent evaluation and application). 
TABLE XIX

COMPARISON OF RESPONDENTS AND CENTER PERSONNEL PREFERENCES OF CLIENT INVOLVEMENT IN CLASS SESSIONS 1990

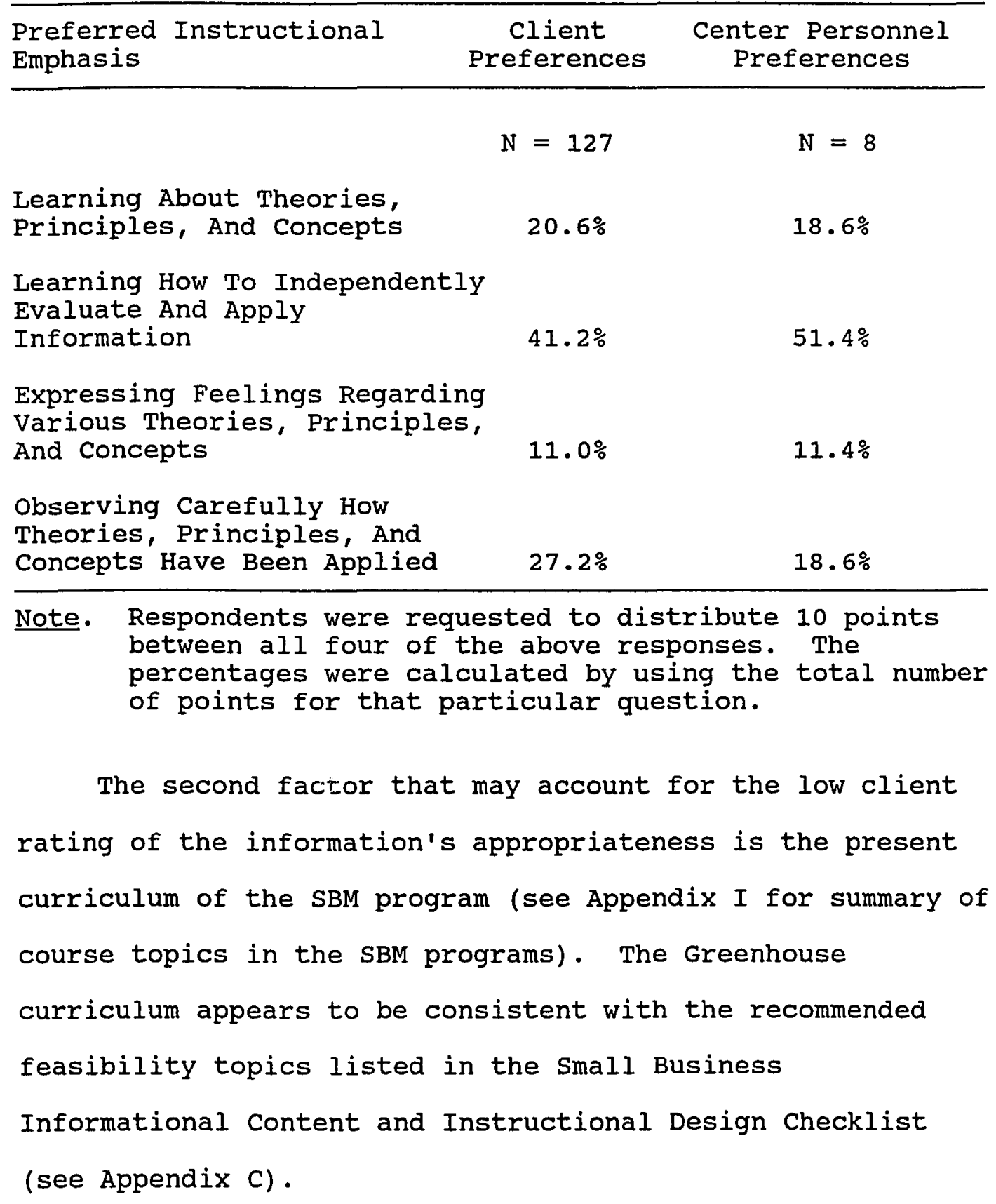


The topics listed in the Small Business Management program appear to cover rudimentary financial and accounting, marketing, planning, and personnel issues and systems. Evaluating the quality of information presented in covering those topics was beyond the scope of this study. However, the topics listed in the printed curriculum appear to be most appropriate for the stage one and stage two companies. The curriculum does not appear to contain the type of courses necessary for assisting stage three clients in accessing the adequacy of their present systems and exploring more advanced systems for organizational growth. To test this premise, seven hypotheses were developed and tested. Each hypothesis related the level of client satisfaction for a specific informational content variable to the small business growth stage of respondents.

\section{Hypotheses Testing}

Before calculating the One-way Anova tests, a series of chi-squares was conducted between the demographic independent variables "age", "gender", and "educational background", and both the Small Business Growth Stage (Number of Employees) and Small Business Growth Stage (Dollar Amount of Assets). The purpose of conducting these chi-squares was to test for the existence of a significant relationship between any of the demographic variables and the respective growth stages. The results of these chi-squares are presented in Table XX. 
TABLE XX

RESULTS OF CHI-SQUARE TESTS BETWEEN KEY

INDEPENDENT DEMOGRAPHIC VARIABLES AND THE SMALL BUSINESS GROWTH STAGE BY NUMBER OF EMPLOYEES AND DOLLAAR AMOUNT OF ASSESTS 1990

\begin{tabular}{|c|c|c|c|c|}
\hline $\begin{array}{l}\text { Independent } \\
\text { Variable }\end{array}$ & $\begin{array}{c}\text { Chi-Square } \\
\text { Value }\end{array}$ & $\begin{array}{c}\text { Degrees of } \\
\text { Freedom }\end{array}$ & Probability & Comments \\
\hline \multicolumn{5}{|c|}{ Number of Employees } \\
\hline Age & 2.036 & 4 & .729 & \\
\hline Gender & 4.121 & 2 & .127 & \\
\hline Education & 3.577 & 4 & .466 & \\
\hline \multicolumn{5}{|c|}{ Dollar Amount of Assets } \\
\hline Age & 2.022 & 4 & .732 & \\
\hline Gender & 6.977 & 2 & .031 & significant \\
\hline Education & 2.756 & 4 & .599 & \\
\hline
\end{tabular}

Because of the significant relationship found to exist between the independent variable "Gender" and the independent variable "Small Business Growth Stage" (Dollar Amount of Assets), a series of Analysis of Covariance tests was conducted to correct for the effects of the variable "Gender" upon the significant F-test ratios found when utilizing the "Small Business Growth Stage (Dollar Amount of Assets)". The multiple comparison method Tukey-Cramer was utilized between each paired combinations of means for the 
four "Small Business Growth Stages" for each One-way Anova test.

Table XXI presents the results of the six one-way anovas that were conducted in order to test for the existence of significant differences in respondent ratings of short-term counseling program variables by Small Business Growth Stage (Number of Employees). No significant differences were found to exist based upon small business growth stage.

TABLE XXI

F-TEST RATIOS OF SHORT-TERM COUNSELING VARIABLES BY SMALI BUSINESS GROWTH STAGE

(NUMBER OF EMPLOYEES) 1990

\begin{tabular}{lcc}
\hline Program Variables & F-Test & Ratio Probability \\
\hline Counselor's Knowledge & .248 & .86 \\
Counselor's Suggestions & 2.200 & .09 \\
Counselor's Promptness & 1.062 & .37 \\
Counselor's Courteousness & .596 & .62 \\
Counselor's Understanding & 1.010 & .39 \\
Materials Provided & 1.162 & .33 \\
\hline
\end{tabular}

Table XXII presents the results of both the six analysis of covariance and six one-way anovas that were conducted to test for the existence of significant differences in respondent ratings of short-term counseling program variables based upon Small Business Growth stage 
(Dollar Amount of Assets). No significant differences were found to exist based upon small business growth stage.

TABLE XXII

F-TEST RATIOS OF SHORT-TERM COUNSELING VARIABLES

BY SMALL BUSINESS GROWTH STAGE

(DOLLAR AMOUNT OF ASSETS)

1990

\begin{tabular}{lcccc}
\hline & & & \multicolumn{2}{c}{$\begin{array}{c}\text { Covaried with } \\
\text { Variable "Gender" }\end{array}$} \\
$\begin{array}{l}\text { Program } \\
\text { Variables }\end{array}$ & $\begin{array}{c}\text { F-Test } \\
\text { Ratio }\end{array}$ & Probability & $\begin{array}{c}\text { F-Test } \\
\text { Ratio }\end{array}$ & Probability \\
\hline $\begin{array}{l}\text { Counselor's } \\
\text { Knowledge }\end{array}$ & .417 & .74 & .354 & .79 \\
$\begin{array}{l}\text { Counselor's } \\
\text { Suggestions }\end{array}$ & 1.013 & .39 & .981 & .40 \\
$\begin{array}{l}\text { Counselor's } \\
\text { Promptness }\end{array}$ & 1.587 & .20 & 1.770 & .16 \\
$\begin{array}{l}\text { Counselor's } \\
\text { Courteousness }\end{array}$ & .181 & .91 & .313 & .82 \\
$\begin{array}{l}\text { Counselor's } \\
\text { Understanding }\end{array}$ & 1.351 & .26 & 1.488 & .22 \\
$\begin{array}{l}\text { Materials } \\
\text { Provided }\end{array}$ & 1.035 & .38 & 1.038 & .38 \\
\hline
\end{tabular}

Table XXIII presents the results of the eight one-way anovas that were conducted to test for the existence of significant differences in respondent ratings of SBM program variables based upon Small Business Growth Stage (Number of Employees). Significant differences were found to exist in 
respondent ratings of the "Appropriate Information" and "Instructor's Knowledge."

TABLE XXIII

F-TEST RATIOS OF SMALL BUSINESS MANAGEMENT PROGRAM

VARIABLES BY SMALL BUSINESS GROWTH STAGE

(NUMBER OF EMPLOYEES)

1990

\begin{tabular}{lccc}
\hline Program Variables & F-Test Ratio & Probability & Comments \\
\hline $\begin{array}{l}\text { Appropriate } \\
\text { Information }\end{array}$ & 3.171 & .03 & significant \\
$\begin{array}{l}\text { Instructor's } \\
\text { Knowledge }\end{array}$ & & .01 & significant \\
Client & & & \\
Participation & 4.521 & .25 & \\
$\begin{array}{l}\text { Counseling } \\
\text { Portion } \\
\text { Class Ratio }\end{array}$ & 1.387 & .22 & \\
Counseling Hours & 1.501 & .04 & \\
$\begin{array}{l}\text { Instructional } \\
\text { Methods } \\
\text { Effectiveness }\end{array}$ & .482 & .70 & \\
$\begin{array}{l}\text { Variety of } \\
\text { Instructional } \\
\text { Methods }\end{array}$ & 1.360 & .26 & \\
\hline
\end{tabular}

Table XXIV presents the results of both the six analyses of covariance and six one-way anovas that were conducted to test for the existence of significant differences in respondent ratings of SBM program variables based upon Small Business Growth Stage (Dollar Amount of 
Assets). A significant difference was found to exist in respondent rating of the "Instructor's Knowledge."

TABLE XXIV

F-TEST RATIOS OF SMALI BUSINESS MANAGEMENT PROGRAM

VARIABLES BY SMALL BUSINESS GROWTH STAGE

(DOLLAR AMOUNT OF ASSETS)

1990

\begin{tabular}{|c|c|c|c|c|c|}
\hline \multirow[b]{2}{*}{$\begin{array}{l}\text { Program } \\
\text { Variables }\end{array}$} & \multirow[b]{2}{*}{$\begin{array}{l}\text { F-Test } \\
\text { Ratio }\end{array}$} & \multirow[b]{2}{*}{ Prob. } & \multicolumn{2}{|c|}{$\begin{array}{l}\text { Covaried with } \\
\text { Variable "Gender" }\end{array}$} & \multirow[b]{2}{*}{ Comments } \\
\hline & & & $\begin{array}{l}\text { F-Test } \\
\text { Ratio }\end{array}$ & Prob. & \\
\hline \multicolumn{6}{|l|}{ Appropriate } \\
\hline Information & 1.750 & .17 & 1.747 & .17 & \\
\hline \multicolumn{6}{|l|}{ Instructor's } \\
\hline Knowledge & 3.166 & .03 & 3.371 & .02 & significant \\
\hline \multicolumn{6}{|l|}{ client } \\
\hline \multicolumn{6}{|l|}{ Counseling } \\
\hline Portion & 1.530 & .22 & 1.495 & .22 & \\
\hline class Ratio & .929 & .43 & .906 & .44 & \\
\hline \multicolumn{6}{|l|}{ Counseling } \\
\hline Hours & 1.239 & .30 & 1.220 & .31 & \\
\hline \multicolumn{6}{|l|}{$\begin{array}{l}\text { Instructional } \\
\text { Methods }\end{array}$} \\
\hline Effectiveness & .490 & .69 & .449 & .72 & \\
\hline \multicolumn{6}{|l|}{$\begin{array}{l}\text { Variety of } \\
\text { Instructional }\end{array}$} \\
\hline Methods & 1.757 & .16 & 1.779 & .16 & \\
\hline
\end{tabular}

Table XXV presents the means of these significant program variables by client small business growth stage. 
TABLE XXV

SIGNIFICANT PROGRAM VARIABLES

BY CLIENT SMALL BUSINESS GROWTH STAGE 1990

\begin{tabular}{|c|c|c|c|c|}
\hline Program Variables & $\begin{array}{r}\text { Growth } \\
\text { Stage }\end{array}$ & $\begin{array}{c}\text { Number of } \\
\text { Cases }\end{array}$ & Mean & $\begin{array}{l}\text { Standard } \\
\text { Deviation }\end{array}$ \\
\hline & Number of & Employees & & \\
\hline \multirow{4}{*}{$\begin{array}{l}\text { Appropriate } \\
\text { Information }\end{array}$} & Pre-stage 1 & 10 & 3.100 & 1.370 \\
\hline & 1 & 30 & 3.700 & 1.088 \\
\hline & 2 & 26 & 4.077 & 1.017 \\
\hline & 3 & 5 & 2.800 & 0.837 \\
\hline \multirow{5}{*}{$\begin{array}{l}\text { Instructor's } \\
\text { Knowledge }\end{array}$} & Pre-stage 1 & 11 & 3.545 & 1.368 \\
\hline & 1 & 30 & 4.400 & 0.814 \\
\hline & 2 & 27 & 4.222 & 0.751 \\
\hline & 3 & 5 & 3.200 & 0.447 \\
\hline & Dollar Amour & nt of Asset & & \\
\hline \multirow{4}{*}{$\begin{array}{l}\text { Instructor's } \\
\text { Knowledge }\end{array}$} & Pre-stage 1 & 11 & 3.545 & 1.368 \\
\hline & 1 & 18 & 4.278 & 0.752 \\
\hline & 2 & 37 & 4.324 & 0.818 \\
\hline & 3 & 7 & 3.571 & 0.787 \\
\hline
\end{tabular}

Note. Base upon the following "5 - 1" interval scale: Highly Agree $\begin{array}{lllllll}5 & 4 & 3 & 2 & 1 \\ \text { Highly Disagree. }\end{array}$

Table XXVI presents the Tukey-cramer comparison tests for significance between the client Small Business Growth Stage (Number of Employees) means of the program variable "Appropriate Information." There was a significant 
difference between the means of stage two and stage three companies.

TABLE XXVI

TUKEY-CRAMER COMPARISON TESTS FOR SIGNIFICANCE

SMALI BUSINESS MANAGEMENT PROGRAM VARIABLE:

APPROPRIATE INFORMATION BY SMALL BUSINESS GROWTH STAGE

(NUMBER OF EMPLOYEES)

1990

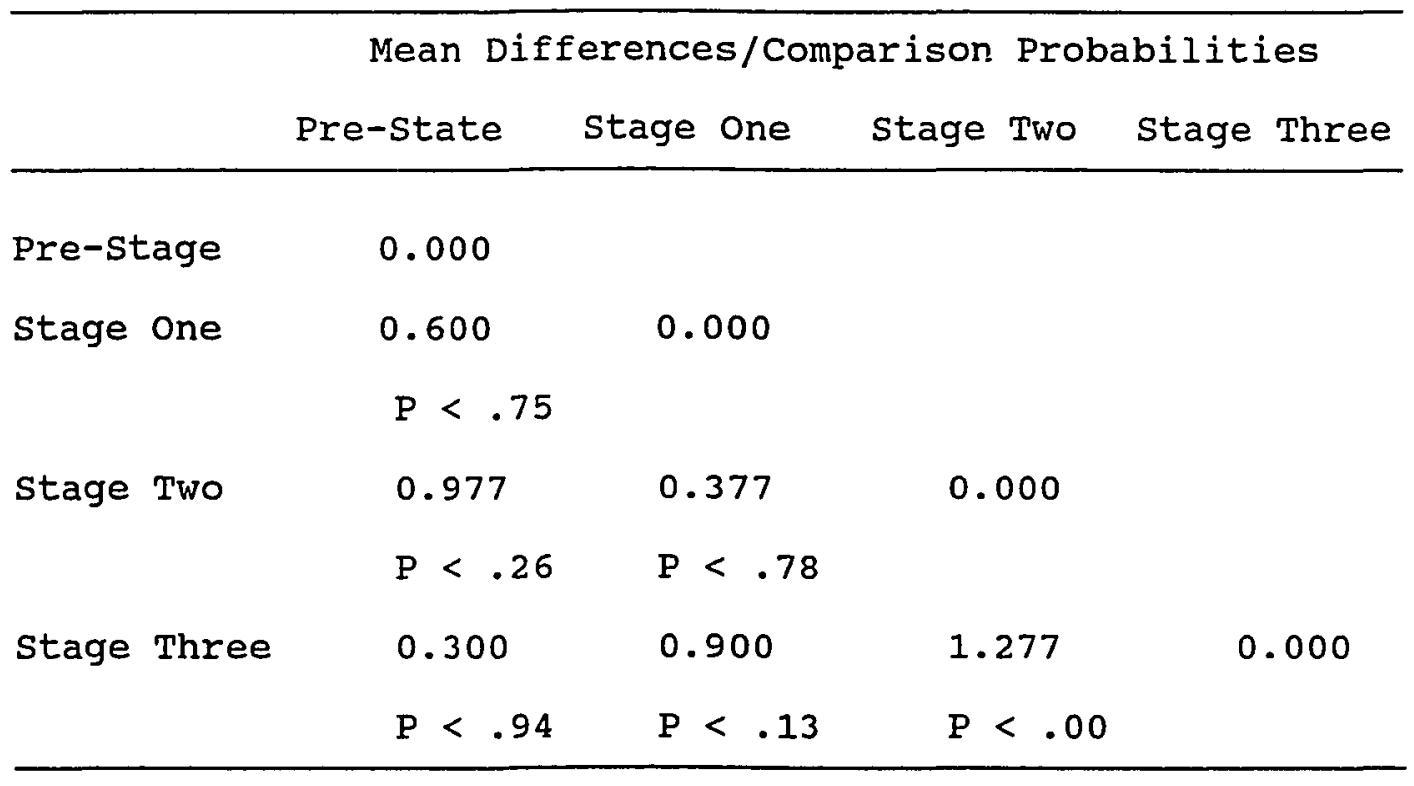

Table XXVII presents the Tukey-Cramer Comparison tests for significance between the client Small Business Growth Stage (Number of Employees) means for the program variable "Instructor's Knowledge." Significant differences were found to exist between the means of stage one and stage three companies, and stage two and stage three companies. 
TABLE XXVII

TUKEY-CRAMER COMPARISON TESTS FOR SIGNIFICANCE SMALL BUSINESS MANAGEMENT PROGRAM VARIABLE: INSTRUCTOR'S KNOWLEDGE BY SMALL BUSINESS GROWTH STAGE (NUMBER OF EMPLOYEES) 1990

\begin{tabular}{|c|c|c|c|c|}
\hline & \multicolumn{4}{|c|}{ Mean Differences/Comparison Probabilities } \\
\hline & Pre-state & stage one & Stage Two & Stage Three \\
\hline Pre-stage & 0.000 & & & \\
\hline Stage one & 0.855 & 0.000 & & \\
\hline & $\mathrm{P}<.28$ & & & \\
\hline Stage Two & 0.677 & 0.178 & 0.000 & \\
\hline & $\mathrm{P}<.40$ & $\mathrm{P}<.94$ & & \\
\hline Stage Three & 0.345 & 1.200 & 1.022 & 0.000 \\
\hline & $P<.85$ & $P<.00$ & $\mathrm{P}<.00$ & \\
\hline
\end{tabular}

Table XXVIII presents the Tukey-Cramer Comparison tests for significance between the client Small Business Growth Stage (Dollar Amount of Assets) means for the program variable "Instructor's Knowledge." A significant difference was found to exist between the means of a stage two and stage three companies. 
TABLE XXVIII

TUKEY-CRAMER COMPARISON TESTS FOR SIGNIFICANCE

SMALL BUSINESS MANAGEMENT PROGRAM VARIABLE:

INSTRUCTOR'S KNOWLEDGE BY SMALL BUSINESS GROWTH STAGE (DOLLAR AMOUNT OF ASSETS)

1990

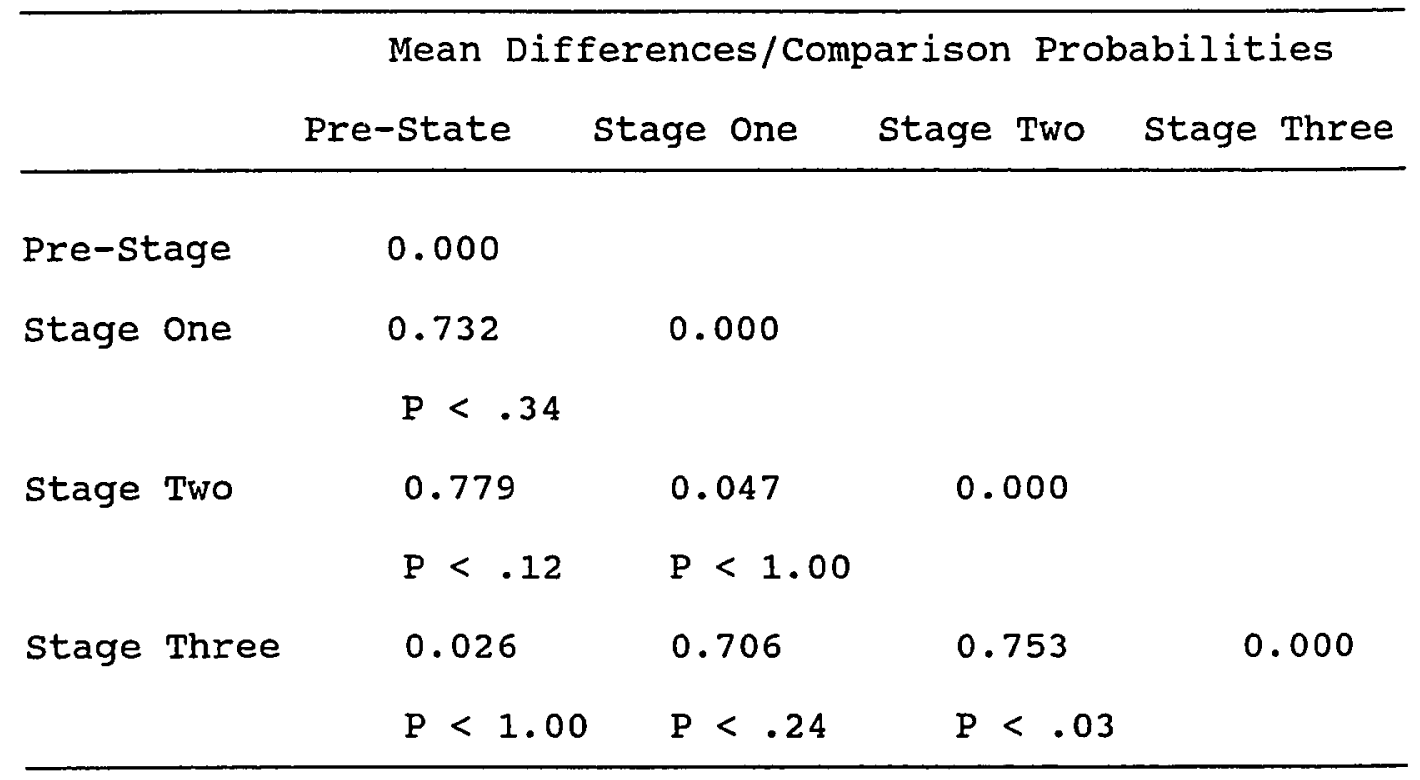

Analysis of Hypothesis Testing

The results of the hypotheses testing revealed that within the stage two/stage three comparisons, the lower stage three client ratings for the variables "Information Appropriateness" and "Instructor's Knowledge" were found to be statistically significant. While the composite client mean for Appropriate Information was 3.690, an analysis of respondents categorized by growth stage (number of employees method) revealed a range of means from a high of 4.077 for stage two clients to a low of 2.800 for stage three clients. This result would appear to support the assumption that 
stage three clients desire more sophisticated knowledge and skills than those presented in the small Business Management Program.

The mean for pre-stage one clients (feasibility study) was 3.100 , which places their level of satisfaction at the low end of the range. At the time this study was being conducted, a new Greenhouse workbook was being developed. A survey of Greenhouse clients using the new workbook should be conducted to see if the new material is deemed more appropriate by respondents.

The composite client mean for Instructor's Knowledge was 4.123 . When the number of employees criteria was used to categorize respondents by growth stage, the means ranged from 4.400 for stage one clients to 3.200 for stage three clients. When the dollar amount of assets criteria was used, the means ranged from 4.324 for stage two clients to 3.571 for stage three clients. It both tests, there was a statistically significant decline in respondent evaluation of the instructor competency when clients reached stage three.

One factor that may influence this decline in the stage three evaluation of instructor knowledge is the process used in finalizing the curricular design of the Small Business Management Program (see Appendix H, question 12). Clients are involved in the curriculum decision process at the initial class meeting. The class is asked whether there are 
other topical areas that should be substituted for recommended curriculum. once group consensus is obtained, instructors select the specific material based on their initial impressions of the clients' business knowledge and individual technical sophistication level. Because classes have few stage three participants, the group consensus process may create a curxiculum that is eveñ less relevant for them than originally designed.

ANALYSIS OF PROGRAM INSTRUCTIONAL AND CURRICULAR DESIGN

Table XXIX presents the client means of program variables directly related to the instructional and curricular design of Greenhouse and Small Business Management programs (SBM programs).

The instructional and curricular program variables received the lowest client ratings of all program variables in the study $(3.384-3.630)$. Respondents rated their participation in the planning and coordination of the curricular design of the SBM program lowest of all program variables $(3.384)$. One factor that appears to have influenced this low client rating is the relevance of the material to the needs of the organization. Approximately 60 percent (41 respondents) said that they would like to have been more personally involved in tailoring the program to meet specific company needs (see Table XXX). 
TABLE XXIX

\section{RESPONDENT EVALUATION OF INSTRUCTIONAL AND CURRICULAR PROGRAM VARIABLES FOR SMALL BUSINESS MANAGEMENT PROGRAMS 1990}

\begin{tabular}{lccc}
\hline Program Variables & $\begin{array}{c}\text { Number of } \\
\text { Clients }\end{array}$ & Mean & $\begin{array}{c}\text { Standard } \\
\text { Deviation }\end{array}$ \\
\hline $\begin{array}{l}\text { Client Participation } \\
\begin{array}{l}\text { Instructional Methods } \\
\text { Effectiveness }\end{array}\end{array}$ & 73 & 3.384 & 1.101 \\
$\begin{array}{l}\text { Variety of } \\
\text { Instructional Methods }\end{array}$ & 71 & 3.630 & 1.112 \\
\hline
\end{tabular}

Note. Base upon the following "5 - 1" interval scale: Highly Agree $\begin{array}{llllll}5 & 4 & 3 & 1 \\ \text { Highly Disagree. }\end{array}$

TABLE XXX

INSTRUCTIONAL AND CURRICULAR INVOLVEMENT DESIRED BY CLIENTS 1990

\begin{tabular}{lc}
\hline \multicolumn{1}{c}{ Area of Involvement } & Number of clients \\
\hline Assessment of company's problems & $19(46.34 \%)$ \\
$\begin{array}{l}\text { Assessment of company's long-term } \\
\text { goals }\end{array}$ & $19(46.34 \%)$ \\
$\begin{array}{l}\text { Assessment of personal managerial } \\
\text { skills }\end{array}$ & $22(53.66 \%)$ \\
$\begin{array}{l}\text { Selection of information to be } \\
\text { covered }\end{array}$ & $17(41.46 \%)$ \\
selection of instructional methods & $19(46.34 \%)$ \\
\hline
\end{tabular}

Note. Percentages are over 100 percent because of multiple selections by respondents. 
The lecturing and small business group instructional methods that instructors said they used every class session (Appendix H) appear to agree with the respondents' opinion that these are the best methods for learning to take place (see Table XXXI).

TABLE XXXI

\section{BEST INSTRUCTIONAL METHODS FOR \\ LEARNING TO TAKE PLACE \\ 1990}

\begin{tabular}{lc}
\hline \multicolumn{1}{c}{ Method } & Clients \\
\hline Small Group Discussions & $109(82.0 \%)$ \\
Lectures & $98(73.7 \%)$ \\
Films/Video Tapes & $67(50.4 \%)$ \\
Role Playing & $27(20.3 \%)$ \\
Computer Simulations & $23(17.3 \%)$ \\
\hline
\end{tabular}

Note. Percentages are greater than 100.00 percent because of multiple selections by respondents.

The film/video tape instructional method received 50.4 percent of the responses and should be seriously considered for use in the SBM program.

Using the Small Business Informational Content And Instructional Design Program Checklist (see Appendix C) to review the instructional and curricular design of the SBM program revealed that instructors did not utilize team building exercises, client preferred learning styles, and the systematic involvement of clients in selecting 
instructional methods and evaluating the program throughout the course of study. All of these recommended procedures tend to increase the learner's perception of program ownership and the relevancy of the material to their goals and objectives.

\section{PERCEIVED BENEFITS OF ASSISTANCE}

Table XXXII reveals that approximately one-half (47 percent) of the respondents felt the assistance they received helped them start their business. Although 38.3 percent of the clients said the assistance was not helpful in starting a business, this may be the result of an effective program which discourages infeasible business ideas.

Approximately one-third of the respondents felt the assistance helped them to stay out of financial trouble, increase sales, and increase profits. It is impossible to tell whether the "no" and "do not know" responses reflect the informational content of the program or the short time period between seeking assistance in 1989 and the date of this study. A longitudinal study of clients should be instituted to clarify this matter.

only 6.5 percent of the respondents said that the center's assistance was helpful in increasing employee levels. This may also be a reflection of the time period 
between seeking assistance and the study or simply

businesses not desiring to increase employment levels.

TABLE XXXII

CLIENT PERCEIVED BENEFITS OF THE PROGRAM 1990

\begin{tabular}{|c|c|c|c|c|c|c|c|c|c|c|}
\hline \multirow[b]{2}{*}{ Yes } & \multicolumn{2}{|c|}{$\begin{array}{c}\text { Start } \\
\text { Business }\end{array}$} & \multicolumn{2}{|c|}{$\begin{array}{c}\text { Avoid } \\
\text { Financial } \\
\text { Trouble }\end{array}$} & \multicolumn{2}{|c|}{$\begin{array}{c}\text { Increased } \\
\text { Sales }\end{array}$} & \multicolumn{2}{|c|}{$\begin{array}{c}\text { Increased } \\
\text { Profits }\end{array}$} & \multicolumn{2}{|c|}{$\begin{array}{l}\text { Increased } \\
\text { Employees }\end{array}$} \\
\hline & 54 & $47.0 \%$ & 44 & $36.7 \%$ & 39 & $32.8 \%$ & 36 & $30.5 \%$ & 7 & $6.5 \%$ \\
\hline No & 44 & $38.3 \%$ & 28 & $23.3 \%$ & 37 & $31.1 \%$ & 39 & $33.1 \%$ & 57 & $53.3 \%$ \\
\hline \multirow[t]{2}{*}{$?$} & 17 & $14.7 \%$ & 48 & $40.0 \%$ & 43 & $36.1 \%$ & 43 & $36.4 \%$ & 43 & $40.2 \%$ \\
\hline & 115 & $100.0 \%$ & 120 & $100.0 \%$ & 119 & $100.0 \%$ & 118 & $100.0 \%$ & 107 & $100.0 \%$ \\
\hline
\end{tabular}

SUMMARY OF OVERALL STUDY FINDINGS

The study found that respondents were primarily from businesses that had been in operation for a relatively short period of time, employed limited numbers of workers, and were in the service industry. Most of these companies were stage one and stage two businesses. Owners of these businesses were well educated and primarily middle aged. Their major motivation for seeking assistance for the clackamas Center was to find solutions to specific business problems. 
The Small Business Management Program variable "Appropriate Information" received one of the lowest client ratings of all the informational content variables in the study. Two factors that were suggested as possibly influencing this low client rating were differences in client/center personnel expectations and the curricular content of the program. Clients appear to envision the appropriate role for the instructor as that of a consultant. The short-term applicability of information to business problems appears to be more highly valued by clients than the potential long-term benefits of learning management theory. Center personnel see their role in a more traditional instructor/student role. The purpose of the program is to help clients develop their own long-term problem solving capabilities.

Using the Small Business Informational content and Instructional Design Program Checklist as a guide, the study found that the Greenhouse curriculum covered the major topics of a comprehensive feasibility study. The topics listed in the Small Business Management curriculum were found to be most appropriate for the stage one and stage two companies.

The study found that there existed a significant decline in the stage three clients' evaluation of the informational content of the program. The results of the hypotheses testing revealed that within the stage two/stage 
three client comparisons, the lower stage three client ratings for the informational content variables "Information Appropriateness" and "Instructor's Knowledge" were found to be statistically significant. The process by which instructors finalize the curriculum development was suggested as one factor that might influence the lower stage three client rating of the "Instructor's Knowledge."

The study found that instructional and curricular program variables received the lowest client ratings of all program variables in the study. Respondents were least satisfied with their participation in the planning and coordination of the program to meet the specific needs of their company. This again appears to be related to the appropriateness of informational content. Clients said that they desired to be more involved in assessing company problems, long-term goals, and their own managerial skills. clients and instructors agreed that lectures and small group discussions were the best instructional methods to be used in classes. The SBM program did not exhibit the use of team building exercises, client preferred learning styles, and the formal involvement of clients in selecting instructional methods and the continual evaluation of their educational experience. 


\section{CHAPTER V}

SUMMARY, CONCLUSIONS, AND RECOMMENDATIONS

SUMMARY

The purpose of this study was to analyze how the Clackamas Center's Small Business Management Program contributed to improving the managerial and administrative skills of clients. The scope of this study was limited to these three research objectives: to ascertain what information should be transferred to small business owners and how best to transfer that information; to ascertain what information is presently being transferred to clients and what methods are used in transferring that information; and to survey clients in order to develop a current demographic profile, measure their level of satisfaction with the assistance received, and ascertain what they perceived were the benefits of the program to their companies.

The first objective of establishing a recommended body of information to be transferred to clients was developed from the small business growth model literature. The recommended methods of transferring this information were developed from the adult learning literature. This collection of information and instructional methods was incorporated into a "Small Business Informational content 
And Instructional Design Program Checklist." This checklist was used as a tool in analyzing the client surveys, Clackamas center Personnel interviews, and the materials used in the Greenhouse and Small Business Management programs. The study was conducted in two phases, a client survey phase and a center personnel interview phase.

A client survey was mailed to all 488 individuals that sought assistance from the clackamas center during 1989. The survey instrument consisted of the following: ten general demographic questions; a fourteen item question, "Client Evaluation of The Program: Counseling, Greenhouse and Small Business Management Programs," containing declarative statements related to informational content variables with a five point interval scale; three program improvement questions; one benefits perception question; and a seven item question, "Training style Preferences Inventory" (Wheeler \& Marshall, 1986), containing declarative statements related to instructional preferences. The response rate to the client survey was 29.5 percent (144 respondents).

The sample contained clients who had participated in both the Short-term Counseling Program and the Small Business Management Programs (53.2 percent) and clients who had participated only in the Short-term Counseling Program (46.8 percent). Approximately 18 percent of the clients were considering the feasibility of starting a new business. 
The remaining 72 percent were primarily from stage one and stage two companies that had been in operation for less than five years, employed five or fewer employees, and were in the service industry. Respondents were primarily between 30 and 49 years old (71.9 percent) and 36.3 percent had completed at least some post-graduate college work. Over one-half of the respondents ( 55.7 percent) were women. The study found no statistically significant differences in client opinions or evaluations based on gender. Future studies may want to focus on exploring whether women entrepreneurs have special informational or instructional design needs.

The client mean for the small Business Management program variable "Appropriate Information" was the second lowest (3.690) of all nine informational related variables. An analysis of means by the clients' small business growth stage revealed a statistically significant decline in respondent satisfaction between stage two and stage three clients $(4.077$ to 2.800$)$. "Instructor's Knowledge" also showed a statistically significant decline in client means $(4.123)$. When respondents were segmented into growth stages by number of employees, the stage three mean (3.200) was found to be significantly lower than both the stage one mean (4.400) and stage two mean (4.222). When clients were categorized by dollar amount of assets, the stage three mean 
(3.571) was found to be significantly lower than the stage two mean $(4.324)$.

The SBM instructional and curricular variables received the lowest client means of all program variables in the study $(3.384-3.630)$. Approximately 60 percent of the respondents desired to be more involved in tailoring the SBM program to the needs of their company.

Approximately one-third of the respondents perceived the assistance they received as helping them to stay out of financial trouble, increase sales, and increase profits. only 6.5 percent of clients felt the assistance was helpful in increasing the number of their employees.

During the second phase of the study, a series of in-depth interviews was conducted with the eight center personnel involved in the Short-term counseling and Greenhouse/Small Business Management Programs. The foci of this phase was to ascertain what standard processes, procedures, and systems were used in assisting clients; what factors were used by center personnel in developing the informational and instructional design of the assistance; and how clients were involved in the planning, coordinating, and the delivery of the assistance.

The center personnel instrument consisted of the following: nine questions related to factors and procedures personnel utilized in designing the program informational content; one instructional methods question; three client 
involvement questions; and a seven item question, "Training Style Preferences Inventory" (Wheeler \& Marshall, 1986), containing declarative statements related to instructional preferences. The study found that all clients go through an initial counseling session with one of the eight individuals involved in the Short-term counseling or SBM programs. Center personnel determine whether to recommend the Greenhouse or Small Business Management programs to clients at this initial conference.

Instructors do not use the businesses' sales levels, numbers of employees, dollar amounts of assets, or other standard factors in designing the informational content of the class sessions. The SBM programs did not exhibit the use of team building exercises, client preferred learning styles, or the formal involvement of clients in selecting the instructional methods and continual evaluation of the classroom sessions.

When the responses of clients and center personnel were compared, two important findings emerged regarding the instructional design of the Greenhouse and Small Business Management programs. First, instructors consistently use the lecture and small group instructional methods which clients overwhelming said were the best methods for learning to take place. Second, center personnel and clients differ in their expectations of what the SBM program should accomplish. Center personnel perceive the purpose of the 
program as providing clients with the knowledge and skills necessary for solving their own problems. Clients perceive the purpose as developing solutions for immediate organizational problems. This key perceptual difference may account for the clients lower ratings of the appropriateness of the program's informational content and their involvement in tailoring the program to their needs.

\section{CONCLUSIONS}

One of the major findings of the study was the relevancy and interconnectness of both adult learning theory and small business growth theory in the investigation of the Small Business Development Center Program. Prior to the study, there had been little systematic research of what information should be transferred to SBDC clients and the most effective methods of transferring that information. one purpose of the study was to explore these issues within the context of organizational informational needs and client adult learning needs. Although the 29.5 percent response rate achieved by the client survey limits the generalizability of the study to all oregon Small Business Development Center Network clients or Clackamas Center clients, a number of conclusions can be drawn regarding a sizable portion of the center's clientele. This study's findings suggests that the learning needs and desires of clients may be two of the most important 
factors influencing their evaluation of the program's informational content and instructional design. The behavior exhibited by clients is very aptly described by Houle's (1963) description of the "goal-oriented" learner; Knox's (1986) description of the "passive adult" learner; and Kolb's (1981) description of the "accommodator" learner. A "goal- oriented" learner establishes very precise educational goals and outcomes related to achieving specific personal and/or professional goals.

clients may not have been able to articulate a set of educational goals and outcomes, but the responses of approximately 81 percent of the sample revealed an overwhelming interest in solving very specific business problems. This client preoccupation with finding solutions to specific problems is a logical inference of the small business growth stage model. Most of the clients were from stage one and stage two businesses. The growth model predicts that it is only by stage three that most companies are able to assemble the critical mass of financial and personnel resources needed to ensure long-term endurance and stability. The short-term benefits of immediate solutions to problems took precedence over the the long-term benefits of learning how to become a more effective manager and administrator. This client preoccupation with the immediate situation was clearly evident in their expectations of what 
should be the educational goals and outcomes of the Small Business Management program.

While center instructors envisioned their role in terms of the traditional instructor/student paradigm, clients were exhibiting the perceptions of Knox's (1986) "passive adult learner." Client responses to the "Training style Preferences Inventory" (Wheller \& Marshall, 1986) clearly revealed that they expected the instructor to play the role of the authority figure who is the "transmitter of knowledge and judge of learner achievement" (Knox, 1986, p. 25). The term "passive adult learner" is used in a very narrow sense and should not be understood as descriptive of the overall behavioral pattern of small business entrepreneurs. Individuals who start businesses do not exhibit passive behavior. However, these self-directed, risk takers defer to the expertise of an outside authority in those areas in which they have little knowledge and experience. Thus a highly self-directed business owner with many years of technical product knowledge takes a less dominant stance with regards to managerial and administrative problem solving. This reliance on outside experts in areas where they have little expertise is an integral part of the behavior exhibited by Kolb's (1981) "Accommodator" learner. Accommodators are risk takers who prefer concrete experiences and active experimentation and rely on experts rather than their own problem solving abilities. These 
characteristics were exhibited in the clients' emphasis on the importance of the instructor's problem/solution expertise rather than the long-term benefits of developing their own problem solving abilities. Clients wanted solutions that could be directly applied to their business rather than a discussion of abstract principles and case studies.

Knox (1986) suggests that the most appropriate educational program for the "passive adult learner" should have very specifically prescribed objectives, packaged content, and formal achievement-related testing and assessment to be used in developing learner desired proficiencies. The Small Business Management Program did not appear to exhibit these characteristics. The high degree of flexibility in the selection process and curricular design process may in fact work against meeting the needs of small business owners.

clients are selected for the Greenhouse and Small Business Management Programs based on the counselor evaluation of the business' financial viability and the client's psychological make-up. However, counselors were not provided with a standard body of assessment criteria or instruments to assist them in the assessment process. Counselors appear to have had only their prior knowledge and business experience to guide them in the evaluation process. This discussion is not intended to question the competency 
of counselors and instructors in managerial and administrative knowledge and skills. All of the Clackamas center personnel who were interviewed had either previously owned a small business, owned a small business at that time, and/or had many years of experience working with small businesses. The issue is one of insuring that all clients are consistently and objectively evaluated. This task is greatly simplified when clearly defined assessment standards and tools are incorporated into the process.

During the initial Small Business Management class session, clients are asked if there are alternative topics that should be substituted for the proscribed curriculum that appears in the published brochures. The question is not whether clients should be involved, but to what degree should they be involved? Can they make an informed decision about what they need to know at the beginning of the program? The issue is whether this process lessens the systematic approach of providing clients with a comprehensive curricular design intended to enhance their managerial and administrative abilities. This process may lessen the "passive adult learner's" perception of both the appropriateness of the program's informational content and the competency of the instructor. The skillful guidance of the instructor is crucial to design an adequate curriculum. Factors such as sales levels, employee levels, and dollar asset levels might prove helpful in assisting instructors to 
more closely match class content to client need and technical sophistication.

An analysis of the curricular design of the Small Business Management Program reveals that the program focuses on increasing the clients' awareness of important issues relating to general managerial and operational topic areas. During each class session a new topic is introduced and discussed. Because of the rapidness with which topics are covered, an important question for further study is to what degree are clients able to successfully implement the basic accounting, financial, marketing, and operational systems and structures they study in the SBM program. One unexpected finding was that so few of the respondents were from stage three companies. An analysis of the study suggests several possible reasons. Stage three clients may have been more reluctant to respond or less willing to take the time to participate in the study. Stage three clients may tend to utilize their financial resources to secure assistance initially from other sources. Stage three clients may find the center's assistance inappropriate for their organization's needs and simply drop out of the program. Whatever the reason, the study found that stage three clients rated the SBM curriculum to be less appropriate for their needs. The curriculum does not contain the assessment of present and alternative managerial and operational systems and structures needed by stage three 
companies. This is an important issue for a program designed to assist small businesses, since most organizations do not achieve financial stability until stage three. The SBDC program should explore expanding its curriculum to include the assessment of client managerial and operational systems and structures.

The study found that approximately 82 percent of the clients were from companies in the service industry. The classification criteria of "numbers of employees" and "dollar amount of assets" may be more appropriate for manufacturing companies than service companies. More study needs to be done in investigating whether there are more appropriate factors that can be used to categorize service industry clients.

The study found that approximately 56 percent of the respondents were women. It is not known why such a high proportion of women seek assistance from the SBDC program. No special advertising appeals appear to be directed towards women. No special courses directed at women were included in the curriculum design. Little systematic study has been done regarding whether the needs of women entrepreneurs are markedly different from men. The study found no differences in client evaluation based on gender. This is an area that should be explored further. 
RECOMMENDATIONS TO PROGRAM DEVELOPERS

It is recommended that a formalized system of client management and administrative skills assessment be instituted during the initial counseling session. Approximately 60 percent of the clients who participated in the Greenhouse/Small Business Management programs indicated that a such a formalized assessment program would improve the curricular design of the SBM program. This formalized system should include self-assessment inventory instruments and tests that include direct observation by counselors. Specific areas to be assessed are the clients' own long-term personal and business related goals, and their managerial knowledge, skills, and abilities. This would allow clients and counselors/instructors to evaluate and agree upon what additional skills and knowledge are needed by the client. A learning plan consisting of a specific time frame, learning objectives, a list of educational activities, and an appropriate method of evaluation could then be established. The closer the learning objectives can be directly related to specific business outcomes (i.e., specific increase in sales, profits, etc.) the more relevant the information presented in the SBM program is likely to be perceived by clients.

It is recommended that the Kolb Learning style Inventory also be incorporated into the initial counseling session. This would assist the instructor in designing the 
instructional methods and teaching style that is most effective for individual clients. Depending on the partial learning preference group make-up of the class, instructors may want to consider designing special small group activities around client learning preferences.

It is recommended that instructors develop cases and other instructional materials that directly relate to the businesses of class members. By utilizing actual client companies for instructional illustrations, instructors can underscore the relevancy of the managerial and administrative principles to the clients and hopefully increase the likelihood of achieving their own goals of helping clients learn how to eventually solve their own problems.

\section{RECOMMENDATIONS FOR POLICY MAKERS}

The Oregon Small Business Development Center Network assistance programs should be expanded to cover the needs of stage three companies. It is during stage three when most companies tend to achieve a level of financial stability and provide a rapid increase in the number of jobs produced (from 25 to 250). Expanding OSBDCN's assistance to stage three companies might entail the development of new informational programs, specialized industry programs, and/or expanded Small Business Management Programs to include the system and structure assessment related 
curriculum. Since the use of small group activities was recommended by both clients and center personnel, a separate stage three client program might prove more effective. The organizational and managerial problems, challenges, and interests are more likely to be similar for clients from the same growth stage.

\section{RECOMMENDATIONS FOR FUTURE RESEARCH}

This study should be replicated at other small business development centers within the oregon Small Business Development Center Network. By utilizing the procedures and instruments developed for this study, analysts would be able to evaluate the level of appropriateness of individual

Short-term Counseling and Small Business Management programs of centers across the state. This would assist policy makers in ensuring that the highest program quality is consistently available to clients across Oregon.

A longitudinal study of clients should be developed to investigate the long-term results of the assistance they received from the Small Business Management Program. It is recommended that the initial client survey be conducted as a part of the last class session. This would likely increase the response rate and provide an adequate measurement base for analyzing annual follow-up surveys.

As a part of this longitudinal study, further research should be conducted to investigate the relationship between 
the client's preferred learning style and his or her evaluation of the informational content, and curricular and instructional design of the Small Business Management and other assistance programs. This could be accomplished by substituting the Kolb Learning style Inventory for the Weller and Marshall "Training style Preference Inventory."

A third recommendation for further research is the investigation of what specific systems, skills, and information is needed by stage three businesses in different industries in order to grow. There appears to be little systematic research in this area. This information would assist small business development center administrators in evaluating whether present programs could be modified or new programs developed to meet the needs of stage three companies.

The last recommendation is to investigate the needs of women entrepreneurs. Few studies have analyzed this rapidly growing group. Do the informational and instructional needs of women differ significantly from those of men? Do women-owned companies differ significantly from men-owned business? Is there a considerable difference in the skills, abilities, and knowledge brought to small business ownership by women entrepreneurs?

These research projects would enhance the ability of the Oregon Small Business Development Center Network program to make a systematic and comprehensive contribution to 
improving the managerial and administrative skills of a broader range of clients. OSBDCN can make a positive contribution towards increasing the level of productivity in the U.S. and oregon economies by assisting small businesses to adopt the managerial and technological innovations that will insure their continued long-term viability. 
REFERENCES

Alreck, P. L., \& Settle, R. B. (1985) . The survey research handbook. Homewood, IL: Richard D. Irwin, Inc., 1985.

Aslanian, C. B., \& Brickell, Henry M. (1980). Americans in transition: Life changes as reasons for adult learning. New York: College Entrance Examination Board.

Baily, M. N., \& Chakrabarti, A. K. (1988). Innovation and the productivity crisis. Washington, D.C.: The Brookings Institution.

Baily, M. N., \& Blair, M. M. (1988). Productivity and American management. In R. E. Litan, R. Z. Lawrence, \& C. L. Schultz (Eds.), American living standards: Threats and challenges (pp. 178-214). Washington, DC: The Brookings Institution.

Barnes, L. B., \& Hershon, S. A. (1976). Transferring power in the family business. Harvard Business Review, 54 (4), 105-114.

Baumol, W. J., \& McLennen, K. (Eds.) . (1985) . Productivity growth and U.S. competitiveness. New York: Oxford University Press.

Bell, D. (1973). The coming of post-industrial society: A venture in social forecasting. New York: Basic Book, Inc.

Birch, D. L. (1984). The contribution of small enterprise to growth and employment. In H. Giersch (Ed.), New opportunities for entrepreneurship symposium 1983 (pp. 1-17). Tubingen: Institut fur Weltwutschaft an der Universitat Kiel.

Birch, D. L. (1987). Job creation in America: How our smallest companies put the most people to work. New York: The Free Press.

Bookfield, S. D. (1986). Understanding and facilitating adult learning. San Franciso: Jossey-Bass Publishers. 
Bottomore, T. (1981). The decline of capitalism, sociologically considered. In A. Heertje (Ed.), Schumpeter's vision: Capitalism, socialism, and democracy after 40 years (pp. 22-44). United Kingdom: Praeger Special studies.

Bramblett, L. R., \& Flewellen, W. C. (1978). The small business development center program for Georgia. AACSB Bulletin, 14(3), 23-29.

Brinkman, R. L. (1981) . Cultural economics. Portland, Oregon: The Hapi Press.

Brown, F. (1983). Principles of educational and psychological testing (3rd ed.). New York: Holt, Reinholt, \& Winston.

Case, J. (1989). The disciples of David Birch. Inc., $1(1)$, p. 39-45.

Chrisman, J. J., Nelson, R. R., Hoy, F., \& Robinson, R. B., Jr. (1985). The impact of SBDC consulting activities. Journal of Small Business Management, $\underline{23}(3), 1-11$.

Chrisman, J. J., Nelson, R. R., Hoy, F., \& Robinson, R. B., Jr. (1987). Evaluating the impact of SBDC counseling: A reply to Elstrott. Journal of Small Business Management, $\underline{25}(1), 72-75$.

Church, F. (1987, March 10). Budget cuts could imperil business program. Oregonian, pp. D9.

Churchill, N. C., \& Lewis, V. L. (1983). The five stages of small business growth. In D. E. Gumpert (Ed.), Growing concerns: Topics of particular interest to owners and managers of small businesses. Harvard Business Review, 61(3), 30-50.

Clackamas Small Business Development Center. (1985). Annual report. Oregon City, OR: Oregon state Printing Office.

Cohn, T., \& Lindberg, R. A. (1974). Survival and growth: management strategies for the small firm. New York: AMACOM.

Council of Economic Advisors. (1988 - 1989). The economic report of the President. Washington, D.C.: U. S. Government Printing office. 
Crean, M. J., \& Farber, J. (1987). The transition to counseling: Via the crean continuum of crescive companies. The Real Estate Appraiser And Analyst, 53(1), 29-35.

Croft, N. L. (1987). Keeping your business afloat. Nations Business, $75(2), 16-23$.

Cross, K. P. (1981). Adults as learners: Increasing participation and facilitation learning. San Francisco: Jossey-Bass Publishers.

Cuomo Commission on Trade And Competitiveness. (1988). The Cuomo commission report: A new American formula for a strong economy. New York: Simon \& Schuster Inc.

Cutler, E. (1984). Open for business. Community And Junior College Journal, 55, 28-30.

Daloz, L. A. (1986). Effective teaching and mentoring. San Francisco: Jossey-Bass.

DeGregori, T. R. (1985). A theory of technology: Continuity and change in human development. Ames, IA: Iowa State University Press.

Delaney, W. A. (1984). Why small businesses fail - don't make the same mistake once. Englewood cliffs, NJ: publisher.

Drucker, P. F. (1969). The age of discontinuity: Guidelines to our changing society. New York: Harper \& Row, Publishers.

Drucker, P. F. (1985) . Innovation and entrepreneurship: Practice and principle. New York: Harper \& Row, Publishers.

Edmunds, S. W. (1982). Performance measures for growing businesses: A practical guide to small business management. New York: Van Nostrand Reinhold Company, Inc.

Elstrott, J. B. (1987). Procedure for improving the evaluation of SBDC counseling activities. Journal of Smal1 Business Management, $\underline{25}(1), 67-71$.

Flamholtz, E. G. (1986). How to make the transition from an entrepreneurship to a professionally managed firm. San Francisco: Jossey-Bass Publishers. 
Fredland, J. E., \& Morris, C. E. (1976). A cross section analysis of small business failure. American Journal of Small Business, 1(1), 7-18.

Freeman, C. (1981). Innovation as an engine of economic growth: Retrospect and prospects. In H. Giersch (Ed.), Emerging technologies: Consequences for economic growth, structural change, and employment symposium 1981 (pp. 1-32). Tubingen: Institut fur Kiel.

Greiner, L. E. (1972). Evolution and revolution as organizations grow. Harvard Business Review, 50 (4), 37-46.

Hart, H. (1957). Acceleration in social change. In F. R. Allen, H. Hornell, D. C. Miller, W. F. Ogburn, \& M. F. Nimkoff (Eds.), Technology and social change (pp. 2755). New York: Appleton-Century-Crofts, Inc.

Hofer, C. W., \& Charan, R. (1984). The transition to professional management: Mission impossible? American Journal of Small Business, $9(1), 1-11$.

Hoselitz, B. F., Spengler, J. J., Letiche, J. M., McKinley, E., Buttrick, J., \& Bruton, H. J. (1960). Theories of economic growth. Glencoe, IL: The Free Press of Glencoe, 1960.

Houle, c. (1963). The inquiring mind. Madison: The University Press.

Houle. C. (1980). Continuing learning in the professions. San Francisco: Jossey-Bass.

Joint Legislative Interim Task Force on Small Business. (1978). Report of the joint interim task force on small business oregon. Sa!em, OR: Oregon state Printing office.

Kegan, R. (1982). The evolving self: Problem and process in human development. Cambridge: Harvard University Press.

King, P. M. (1978). William Perry's theory of intellectual and ethical development. In L. Knefelkamp, C. Widick, \& C. A. Parker (Eds.). Applying new developmental findings (pp. 35-50). San Francisco: Jossey-Bass Inc. 
Knowles, M. S. (1970). The modern practice of adult education: Andragogy versus pedagogy. New York: Association Press.

Knowles, M. S. (1978). The adult learner: A neglected species. (2nd ed.). Houston: Gulf.

Knowles, M. S., and Associates. (1984). Andragogy in action: Applying modern principles of adult learning. San Francisco: Jossey-Bass Publishers.

Knox, A. B. (1986). Helping adults learn: A quide to planning, implementing, and conducting programs. San Francisco: Jossey-Bass Publishers.

Kolb, D. A. (1976). Learning style inventory:

Self-scoring test and interpretation booklet. Boston: MCBer and Company.

Kolb, D. A. (1981). Today's students and their needs. In A. W. Chickering and Associates (Eds.). The modern American college (pp. 232-255). San Francisco: Jossey-Bass Publishers.

Kolb, D. A. (1984). Experimental learning: Experience as the source of learning and development. Englewood cliffs: Prentice-Hall.

Kroeber, A. L., \& Kluckhow, C. (1952). Culture: A critical review of concepts and definitions. Harvard University, Peabody Museum of American archeology and ethnology papers, $47(1)$, Cambridge: The Museum.

Kuznets, S. (1986). Modern economic growth. New Haven: Yale University Press.

Levinson, D. J. (1980). Toward a conception of adult life course. In N. J. Smelser, \& E. H. Erikson (Eds.). Themes of work and love in adulthood (pp. 265-291). Cambridge: Harvard University Press.

Mishel, L. R. (1989, January-February). The late great debate on deindustrailization. Challenge, pp. 35-43.

Myers, H. F. (1990, December 10). The outlook: Raising productivity will be tough in $90^{\prime} \mathrm{s}$. The Wall street Journal. pp. Al.

Myrdal, G. (1974, September). The transfer of technology to underdeveloped countries. Scientific American, pp. 172-182. 
Myrdal, G. (1974, December 7). What is development? Journal of Economic Issues. pp. 729-736.

Nau, H. R. (1990) . The myth of America's decline: Leading the world economy into the 1990s. New York: oxford University Press.

Neef, A., \& Thomas, J. (1987). Productivity in manufacturing at home and abroad. Monthly Labor Review, 110, pp. 25-30.

Nye, J. S., Jr. (1990). Bound to lead: The changing nature of American power. New York: Basic Books, Inc.

Norton, R. D. (1986). Industrial policy and American renewal. Journal of Economic Literature, XXIV, 1-40.

Oregon Department of Economic Development. (1989). Small business survey. Salem, OR: Oregon state Printing Office.

Oregon Small Business Development Center Network. (1988). OSBDCN 1988 Annual Report. Prepared for U.S. Small Business Administration per Cooperative Agreement SB-2M00100-05. Salem, OR: Oregon State Printing office.

Oregon Small Business Development Center Network. (1989). History of the small business development center network. Salem, OR: Oregon state Printing office.

Owens, T. R. (1985). Evaluation report: Small business development center network. Unpublished report.

Pelham, A. M. (1985, Fall). Should the SBDC program be dismantled? American Journal of Small Businesses Management, pp. 41-51.

Perry, W. G., Jr. (1981). Cognitive and ethical growth: The making of meaning. In $A$. W. Chickering, and Associates (Eds.), The Modern American College (pp. 76-116). San Francisco: Jossey-Bass, Publishers.

Peterson, R. E. (1981). Opportunities for adult learners. In A. W. Chickering, and Associates (Eds.), The Modern American College (pp. 306-332). San Francisco: Jossey-Bass, Publishers. 
Peterson, R. A., Kozmetsky, G., \& Ridgway, N. M. (1983). Perceived causes of small business failures: A research note. American Journal of Small Business, 8(1), 15-19.

President's Commission on Industrial competitiveness. (1985). Global competition: The new reality. (Vols. I-II). Washington, D.C.: U.S. Government Printing Office.

Schatz, K. W. (1985). The contribution of small and new enterprise to growth and employment. In B. G. Gemper (Ed.), Industrial policy structural, dynamics (pp. 21-36). Hamburg: Verlag Weltarchiv Gmbh.

Schumpeter, J. A. (1.983). The theory of economic development. New Brunswick: Transaction Books. (Original work published 1911).

Scott, M., \& Bruce, R. (1987). Five stages of growth in small business. Long Range Planning, 20(3), 45-52.

Small Business Development Center Act of 1980, 96 U.S.C., PL96-302.

Solomon, S. (1986). Small business USA: The role of small companies in sparking America's economic transformation. New York: Crown Publishers, Inc.

Steinmetz, L. L. (1969). Critical stages of small business growth: When they occur and how to survive them. Business Horizons, 12(1), 29-36.

Stevenson, H. H., Roberts, M. J., \& Grousbeck, H. I. (1985). New business ventures and the entrepreneur (2nd ed.). Homewood, IL: Richard D. Irvine, Inc.

Taylor, G. R. (1971). Stage theories of economic history. In Taylor, G. R., \& Ellsworth, L. F. (Eds.). Approaches to American economic history (pp. 25-36). Charlottesville: The University Press of Virginia.

Thurow, L. C. (1985). The zero-sum society: Building a world-class economic economy. New York: Simon and Schuster.

Tough, A. (1968). Why adults learn: A study of the major reason for beginning and continuing a learning project. Monographs in Adult Education, $\underline{3}$. 
Tough, A. (1981). Interests of adult learners. In A. W. Chickering, and Associates. (Eds.). The modern American college (pp. 296-305). San Francisco: Jossey-Bass, Publishers.

U.S. Small Business Administration. (1986). The state of small business: A report of the President transmitted to congress. Washington, DC: U.S. Government Printing office.

U.S. Small Business Administration. (1987). Portland District office. Annual report 1987. Washington, DC: U.S. Government Printing office.

U.S. Small Business Administration. (1989). Office of Advocacy. The states and small business: A directory of program and activities. Washington, DC: U.S. Government Printing office.

Vroom, V. H. (1967). Work in motivation. New York: Wiley and Sons.

Wessel, D., \& Brown, B. (1988, November 8). The hyping of small-firm job growth: Lobbyists use suspect statistics to push causes. The Wall street Journal, B1.

Wheeler, M., \& Marshall, J. (1986). The trainer type inventory (TTI): Identifying training style preferences. In Author (Ed.), The 1986 annual: Developing human resources (pp. 87-97). San Diego: University Associates.

White, J. S., (Ed.). (1983). Business failures: Some disturbing research. CA Magazine, 116(8), 115-117.

Wlodkowski, R. J. (1985). Enhancing adult motivation to learn. San Francisco: Jossey-Bass. 
APPENDIX A

CLACKAMAS SMALL BUSINESS DEVELOPMENT CENTER

CLIENT SURVEY 


\title{
CLACKAMAS SMALL BUSINESS DEVELOPMENT CENTER CLIENT SURVEY
}

\begin{abstract}
Please answer the questions below by writing your answer in the space provided, or by checking the box $x$ which best describes your answer. In describing an experience or problem you've encountered, please be as specific as you can. Thanks for your help in this important program evaluation. Your responses will remain confidential.
\end{abstract}

1. Do you presently own or manage a small business? Yes 0 No 0 If Yes, how long has your company been in business?

2. Please identify the one major business activity of either your present or proposed business: (please check one category) Retail 0 Construction 0 General Service 0 wholesale 0 Manufacturing 0 other (please write in)

Pleage write in your SIC code (if known)

3. When you contacted the SBDC did you have a specific problem to be addressed? Yes 0 No 0

If yes, check all that apply. Accounting, Bookkeeping 0 Business plan preparation 0 Market analysis 0 Financlal assistance 0 Management structure 0 Business feasiblilty 0 Legal 0 Production 0 Inventory control 0 Technical assistance (i.e., product feasibility, engineering) 0 Personnel 0 Marketing 0 other (please write in)

4. Was your speciflc problem addressed by the counzelor? yes o wo 0 If no, what problem(s) was not addressed by the counselor?

5. How satisfied were you with the counseling that you received? very satisfied $\begin{array}{llllll}5 & 4 & 3 & 2 & 1 & \text { very unsatisfied } \\ & 0 & 0 & 0 & 0 & 0\end{array}$

6. Have you participated in any of the following sBDC's programs: Greenhouse program, Small Business Management I Program, small Business Management II Program?

Yes 0 No 0 .

If no, sklp to question 10

If yes, which programs:

Greenhouse :

Small Business Management I

Small Business Management II

$\begin{array}{cc}\begin{array}{c}\text { Present } \\ \text { Completed } \\ \text { Program } \\ 0\end{array} & \begin{array}{c}\text { Presently in } \\ \text { Program }\end{array} \\ 0 & 0 \\ 0 & 0 \\ & 0\end{array}$


7. Are there any additional subjects that should be included in the Greenhouse, Small Business Management, and Profit Improvement Programs? Yes 0 No 0

If yes, what should be included? (Please write in)

Greenhouse

Small Business Mgmt. I

Small Business Mgmt. II

8. Are there any ways in which the counseling portion of Greenhouse and Small Business Management Programs can be improved?

No 0 Yes 0

If yes, whlch of the following options do you believe would Improve the counseling portion of the program:

A. More hours per week should be devoted to counseling 0

B. Total number of hours of counseling should be increased 0

C. Other (please write in)

9. Are there any ways in whlch you would have liked to have been involved in tailoring the Greenhouse and Small Business Management programs to meet the specific needs of your company? No 0 Yes 0

If yes, in which of the following ways would you like to be Involved in the process:

A. Participating in an assessment of your company's problem areas 0

B. Participating in an assessment of your long-term goals and objectives for your company (or prospective company) 0

c. Participating in an assessment of your personal managerlal abilities, skilis, and knowledge 0

D. Participating in the process of selecting the information to be covered in the small Business Management classes 0

E. Farticipating in the selection of instructional methods used in classes (such as lecturing, small group discussions, computer simulations, etc.) 0

F. Other (please specify)

Client Evaluation of The Program

Please check only one box per 1tem:

10. Counse 1 ing:

Highly Highly

$\lambda$. The counselor's knowledge of

problem(s) to be addressed was excellent

Aqree $\begin{array}{llllll}5 & 4 & 3 & 2 & 1 & \text { Disagree }\end{array}$

$\exists$. The counselor's suggestions to solve the problem(s) being discussed were appropriate for the situation

$\begin{array}{lllllllll}0 & 0 & 0 & 0 & 0\end{array}$

. Your request for assistance recelved prompt attention by the counselor

D. The counselor was courteous towards you

E. The counselor understood your long-term goals for your company

F. The materlals provided to you by the counselor were excellent

$\begin{array}{llllll}0 & 0 & 0 & 0 & 0\end{array}$

$\begin{array}{llllll}0 & 0 & 0 & 0 & 0\end{array}$

$\begin{array}{lllllllllll}0 & 0 & 0 & 0 & 0\end{array}$

$\begin{array}{llllllllll}0 & 0 & 0 & 0 & 0\end{array}$

$\begin{array}{lllll}0 & 0 & 0 & 0 & 0\end{array}$ 


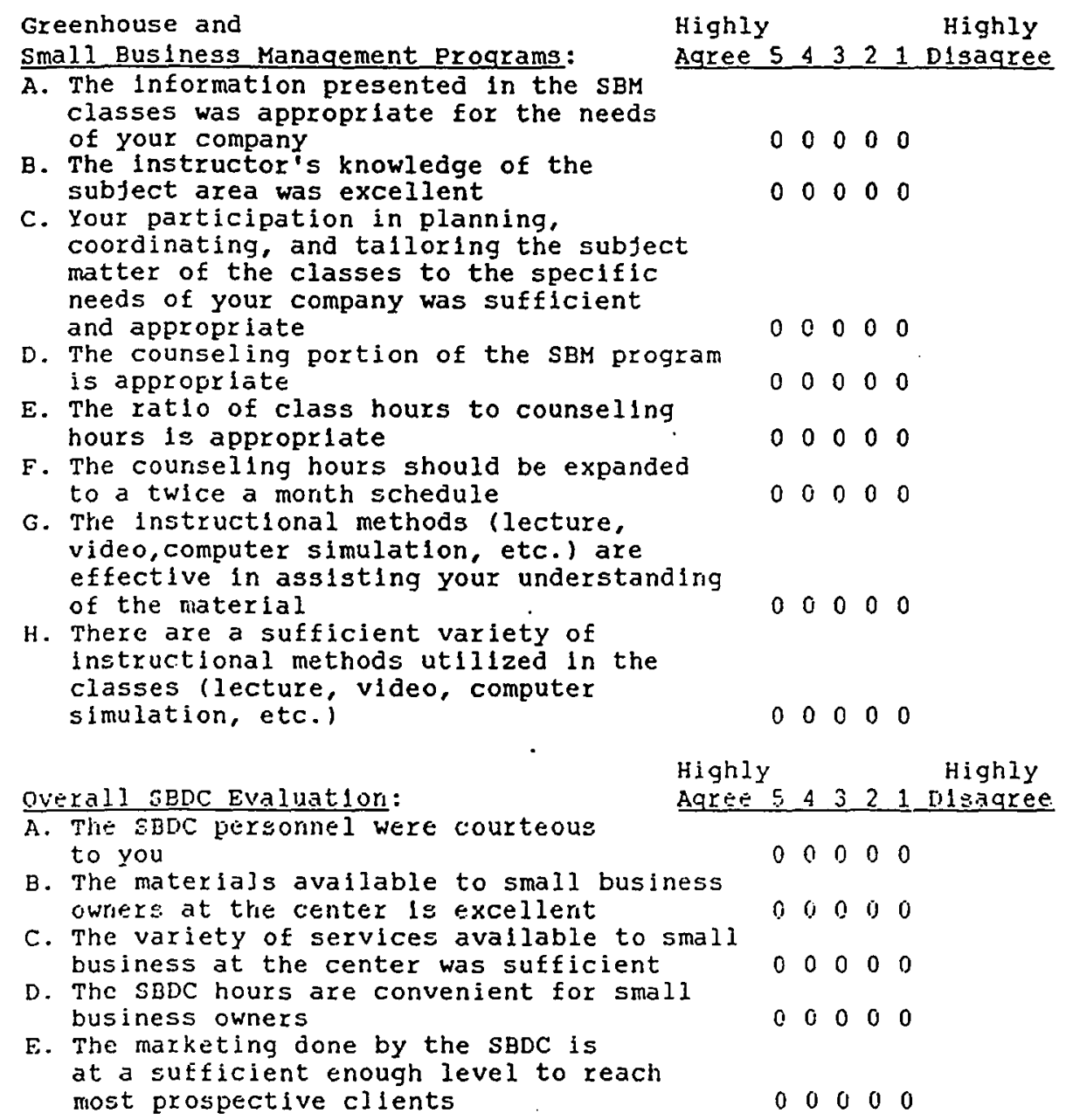

11. In what ways do you learn best? (please check all that apply) Lectures 0 F1lms/Video Tapes 0 small Group Discuselons 0 Role Playing 0 Computer simulations 0 other (please specify)

12. Do you feel that the assistance you received at the SBDC helped you:

start your business

Yes 0 No 0 Don't know 0

Yes o ino 0 Don't know 0

Increase sales? Yes 0 No 0 Don't know 0

Increase profits? Yes 0 No 0 Don't know 0

Increase the number of employees? Yes 0 No 0 Don't know 0 
13. To assist us in making our instructional courses more informative and enjoyable for you, please rate each of the following options by distributing ten (10) points among the four cholces to indicate how intensely you prefer each choice. please always use all ten points. You may use zeros for those options that are not important to you.

Example: In class, I prefer that the instructor encourages clients to: A. share their feelings
B. listen quietiy
C. take notes
D. ask questions

1. In class, I prefer an instructor to emphasize:

A. client-centered discussions

B. lectures

C. problem-solving activities

D. application activities

2. In class, I prefer an instructor to emphasize:

A. theorles

B. skills

C. attitudes

D. perspectives

3. Instructors should see their primary role in class as:

- A. organizing what takes place in class

B. connecting major ideas for clients

C. encouraging clients to participate in class

D. listening to clients

4. In a class, I prefer to be involved in:

A. learning about theorles, princlples, and concepts

B. learning how to develop ways to independently evaluate and apply information discussed in class

c. expressing my feeling regarding various theories, principles, and concepts

D. observing carefully how theories, principles, and concepts have been applied

5. In class, I prefer instructors who emphasize:

A. small group discussions

B. Eree expression of feelings

C. careful organization of material

[j. time for clients to think Independently -

6. I prefer an instructor who is $a(n)$ :

A. expert

B. scholar

C. advisor

D. frlend 
7. I prefer an instructor who is $a(n)$ :

A. coach

B. group fac1litator

C. director

D. interpreter of information -

ABOUT THE SBDC CLIENT

14. Your Age:

$\begin{array}{llll}\text { Under } 21 & 0 & 40-49 & 0 \\ 21-29 & 0 & 50-59 & 0 \\ 30-39 & 0 & 60 \text { or over } & 0\end{array}$

15. Gender of owner or general manager: Male 0 Female 0

16. Your educational background:

High school or less 0

some college

College graduate

Some post-graduate work 0

Post-graduate degree

17. Number of Employees:

$\begin{array}{ll}\text { Haven't started the company } & 0 \\ \text { only owner(s) enployed in company } & 0 \\ 1-5 \text { employees } & 0 \\ 6-10 \text { employees } & 0 \\ 11-24 \text { employees } & 0 \\ 25 \text { employees and above } & 0\end{array}$

18. Dollar value of company assets:

Haven't started the company

start-up capital/assets only

less than $\$ 100,000$

Fron $\leqslant 100,000$ up to $\$ 500,000$

From $\$ 500,000$ up to $\$ 1 \mathrm{million}$

Over $\$ 1$ million

19. Annual sales Volume

Haven't started the company

Less than $\$ 25,000$

Between $\$ 25,000$ and $\$ 100,000$

Between $\$ 100,000$ and $\$ 250,000$

Between $\$ 250,200$ and $\$ 500,000$

$\$ 500,000$ and above 
APPENDIX B

CLACKAMAS SMALL BUSINESS DEVELOPMENT CENTER

PERSONNEL INTERVIEW QUESTIONNAIRE 
CLACKAMAS SMALL BUSINESS DEVELOPMENT CENTER PERSONNEL INTERVIEW QUESTIONNAIRE

\section{(Probe Questions)}

1. How do you see your role in the Greenhouse and small Business Management Programs?

(A. What specifically is the role of the instructor/counselor?)

2. When an individual with a new idea for a business, comes to your office for the first time, what do you do?

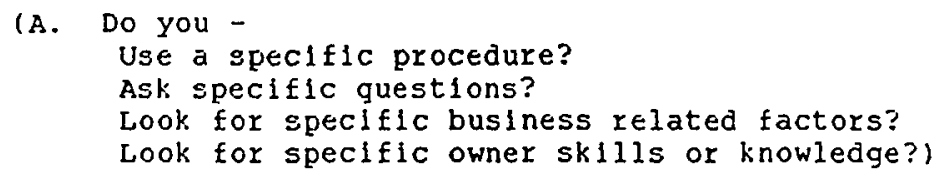

(B. Do you ever recommend that an individual not try to start a new business?

What are the specific factors that would prompt your recommendation?

(C. Do you recomend the Greenhouse Program to everyone who comes to you for assistance?

If not, why not?)

3. If the individual coning to your offlce 1 s the owrer or manager of an actually operating business, what do you do?

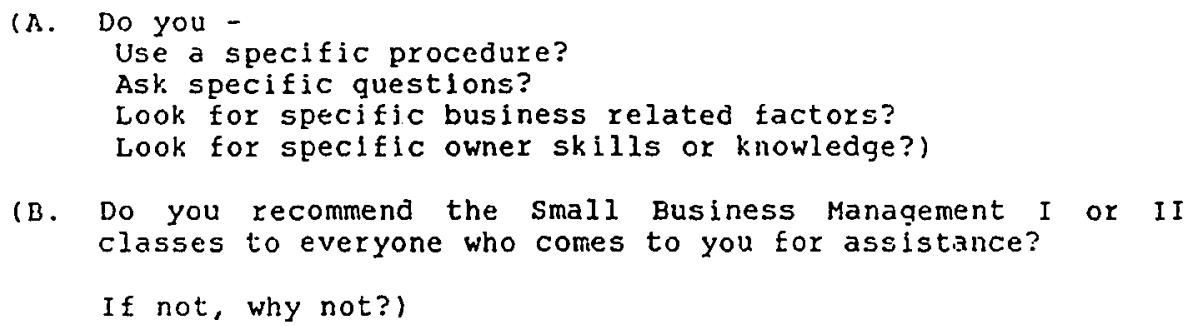

4. Are there specific factors that you believe determine whether a business will be successful or fail?
(A. What are those factors?)
(B. How would you define business success?) business failure? 
5. Do you teach any of the Greenhouse or small Business Management courses?

(A. Which ones?)

6. What should individuals specifically know or be able to do after they have completed the Greenhouse Program?

- SBM I Program

- SBM II Program

7. What materials do you use during the instructional and coungeling sesslons?

8. Are there any of the topic areas that you feel should be specifically emphasized?

(A. How do you emphasize those topic areas?)

9. Are there business related factors that determine what is taught in the instructlonal and/or counseling sesslons?

(A. Such as - company size

- number of employees

- dollar amount of assets

- sales levell

(B. Do you think this might be an important area to look at?)

10. Are the counseling sessions of the Greenhouse, SBM 1 , and SBM 2 programs specifically related to the the topics discussed during the instructional sessions?

(A. How are they related?)

(B. Do you think this might be an important area to look at?)

11. During the instructional sessions and/or counseling sessions, do you use any of the following instructional methods:
A. Lectures
Instructional
B. Computer
Simulations no occasionally often
Counseling
c. Role playing no occasionally often
no occasionaliy often
D. Small Group Activitles no occasionally often
no occasionaliy often
E. Discussion of
personal
experiences no occasionally often
no occasionally often 

F. Case studies no occasionally often
no occasionally often
G. other:
no occasionally often
no occasionally often

12. Are clients involved in selecting and evaluating the instructional methods that are used during class or counseling sessions?

(A. How is this done?)

(B. Do you think this might be an important factor to look at?

13. Are clients involved in selecting the level of information that will be covered during the instructional classes or counseling sesslons?

(A. How is that done?)

(B. Do you think this might be an important factor to look at?)

14. Are clients involved in evaluating the Greerinouse and small Business Management programs?

(A. How is this done?)

(B. Throughout the term?)

At the end of the term?)

(c. How do you utilize this information?)

15. Are there individuals who fail to complete the Greenhouse and SBM programs?

(A. Do you follow-up with these indiviouals to find out why they dropped out of the program?

What reasons do they give?)

16. Are there things about the program that you would like to change? 


\section{INSTRUCTOR TYPE INVENTORY}

\section{INSTRUCTIONS:}

There are 7 sets of 4 words or phrases listed below. You are to distribute ten (10) points among the four cholces to indicate how intensely you prefer each cholce. Always use all ten points. You may use zeros, if they are appropriate, as in this example.

Example: In class, I prefer that clients: A. share their feelings $\underline{0}$

B. Iisten quietly

C. take notes

D. ask questlons

1. In class, I prefer to emphasize:

A. client-centered discussions

B. lectures

C. problem-solving activities

D. application activities

2. In class I prefer to emphasize:
A. theories
B. ekilis
C. attitudes
D. perspectives

3. I see my primary role in class:

A. oxganizing what takes place in class

B. connecting major ideas for clients

C. encouraging clients to participate in class -
D. listening to clients

4. In a class, I prefer to involve the clients in:

A. learning about theorles, princlples, and concepts

E. learning how to develop ways to independently evaluate and apply information discussed in class

c. copressing their feelings regariling various theorses principies, and concepts

D. observing carefuliy how theorles, princlples, and concepts have been applied

5. In class, I prefer to emphasize:

A. small group discussions

B. Eree expression of feelling

C. careful organization of materlal

D. time for clients to think independently

6. I prefer to be seen as $a(n)$ :
A. expert
B. scholar
C. $\operatorname{advizor}$
D. friend

7. I prefer to take the role of:
A. coach
B. group faclititor
C. director
D. Interpreter of information - 


\section{APPENDIX C}

SMALL BUSINESS INFORMATIONAL CONTENT AND INSTRUCTIONAL DESIGN PROGRAM CHECKLIST 


\title{
GYALL BUSINESS INFORMATIONAL CONTENT \\ AND \\ INSTRUCTIONAL DESIGN PROGRAM CHECKLIST
}

\begin{abstract}
The following small business informational content and instructional design checklist was used in evaluating the informational content, and instructional and curricular design of the Greenhouse and Small Business Management Programs. The checkilst is divided into two sections. Section one is comprised of factors that researchers suggest are crucial for individuals to know in evaluating the feasibility of new business ventures and in developing and implemeriting the skilis and systems necessary to support continual organizational growth and stability (steinmetz, 1969; Greiner, 1972; Churchill and Lewis, 1983). Section two focuses upon factors that researchers suggest should be incorporated within the design of programs developed for adult learners (Brookfleld, 1986; Cross, 1981; Daloz, 1986; Wlodkowski, 1985).
\end{abstract}

Program Informational content Factors

This section is divided into two segments. The flrst segment focuses upon those lssues that are particularly pertinent to the individual investigating the feasibility of a new business. The second segment shifts the focus to the pertinent issues for owners of existing small businesses.

Greenhouse Program: Feasibility of The Prospective Business Idea

Prograne deglgned to asolat progpectlve bus libes owires evaluate the feasibility of new business ventures should assist individuals in analyzing whether an opportunity for a new business really does exist through:

1. Assessing whether the proposed company wlil have a conpetitive advantage or disadvantage in:

A. Product techiology

B. Production technology

C. Manaqement technology and skilis

2. Assessing the potential effects of proposed government/legal changes

3. Assessing present customer needs and the potentiai effects of future changes

4. Assessing the dimensions of the business opportunity through egtimating:

A. Potential market size for product

F. Market share of major competitors

D. Probable size of market nlche

E. Probable profitablilty of market niche

F. Time frame for the business opportunity

G. Growth potential of the marliet

\begin{tabular}{|c|c|}
\hline \multicolumn{2}{|c|}{ Informational } \\
\hline PY & $r a n_{i}$ \\
\hline yes & No \\
\hline 0 & 0 \\
\hline 0 & 0 \\
\hline 0 & 0 \\
\hline
\end{tabular}

$0 \quad 0$

0

$\begin{array}{ll}0 & 0 \\ 0 & 0 \\ 0 & 0 \\ 0 & 0 \\ 0 & 0 \\ 0 & 0\end{array}$




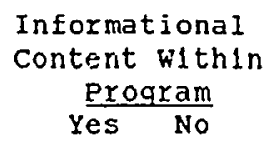

5. Assessing key start-up risk by evaluating:
A. Sufficiency of the initial capital
B. Owner's technical skills
C. Owner's managerial skills
D. Likely competitors' response
E. Ability to obtained the needed resources
F. Ability to establish stable customer base
G. Ability to develop distribution system

$\begin{array}{ll}0 & 0 \\ 0 & 0 \\ 0 & 0 \\ 0 & 0 \\ 0 & 0 \\ 0 & 0 \\ 0 & 0\end{array}$

6. Assessing the value of the opportunity in terms of the individual's:
A. Willingress to invest personal funds
B. Abllity to handle rlsk
C. Non-financial rewards from start-up
D. Short-term and long-term business goals
E. Short-term and long-term personal goals
F. skills and interests

$\begin{array}{ll}0 & 0 \\ 0 & 0 \\ 0 & 0 \\ 0 & 0 \\ 0 & 0 \\ 0 & 0\end{array}$

Small Business Management Program: Assistance For. The Established Small Eus iness organizat ion

Programs can assist small business owners/managers in adopting and adanting the skilis, systems, and structures needed to sustain tie continus. growth and market success of their organlzations through:

$$
\begin{gathered}
\text { Informat lonal } \\
\text { content within } \\
\text { Program } \\
\text { Yes No }
\end{gathered}
$$

1. Assessing the adequacy of present level of capitalization

2. Assisting businesses seek additional capltallation, if reeded, through:
A. Developing accurate financial statements
B. Developing a comprehensive business plan
c. nssisting clients complete required documents 0
D. Assisting clients contact capital sources

3. Assisting owners assess the ir own:
A. Long-term company goals
B. Long-term personal goals
C. Compatibility of both long-term goals
D. Present level of technical skills

$\begin{array}{ll}0 & 0 \\ 0 & 0 \\ 0 & 0 \\ 0 & 0\end{array}$


E. Present level of managerial skills

F. Present level of strateglc planning skilis

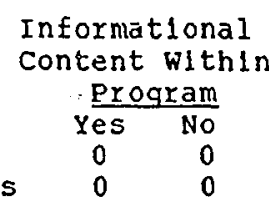

4. Assisting owners assess their company's:

$\begin{array}{lll}\text { A. Present product technology } & 0 & 0 \\ \text { B. eresent production technology } & 0 & 0 \\ \text { C. Exposure to changes in government regulations } & 0 & 0 \\ \text { D. Exposure to shifts in customer demand/needs } & 0 & 0 \\ \text { E. Market thire } & 0 & 0 \\ \text { F. Ergosurs to competitive changes } & 0 & 0 \\ \text { G. Adequacy of training for employees } & 0 & 0 \\ \text { H. Adequacy of trained managers } & 0 & 0 \\ \text { I. Adequacy of accounting \& budget1rg systems } & 0 & 0 \\ \text { J. Adequacy of planning systems } & 0 & 0 \\ \text { K. Adequacy of pergonnel policies } & 0 & 0 \\ \text { L. Adequacy of product development } & 0 & 0 \\ \text { M. Adequacy of marketing systems } & 0 & 0 \\ \text { N. Adeguacy of production systems } & 0 & 0\end{array}$

5. Assistirig owners assess what changes will need to be made in the following areas to accormodate theix long-term company gouls:

A. Accounting \& Budqeting systems

B. Planning and Control systems

C. Informition systems

D. Trainirg for employees

E. Tralnirig for rinaqument pergoniel

F. Level of technical okilis for mariagexs

G. Persommel policles and plans

H. Froduct Develorient

I. Marlieting systems

J. Troduction systems

K. Capitsi structure

M. [listribution systenis.

$\begin{array}{ll}0 & 0 \\ 0 & 0 \\ 0 & 0 \\ 0 & 0 \\ 0 & 0 \\ 0 & 0 \\ 0 & 0 \\ 0 & 0 \\ 0 & 0 \\ 0 & 0 \\ 0 & 0 \\ 0 & 0\end{array}$

Frogram Instructional Design Factors

Researchers have found that adult learners tend to seek out educational programs that they perceive will assist them in obtainling answers to specific professional and/or personal problems and concerns (Brookfield, 1986; Cross, 1981; Daloz, 1986; Wiodkowski, 1985). Though the level of motivation and self-directness of any specific: indjuidual is very difficult to antjcipate and measure, cross has found that motivation and perceived bellefit levels increased dramatically as participants are systematically involved in the desiguiug, coordinating, and on-going evaluation of the program (1981). These researchers suggest that adult learners should be actively encouraged to be joint participants with the instructor in 
assessing needs, developing learning objectives, selecting methods of learning, and assessing the on-going learning experlence.

The following checklist is comprised of factors that research suggests increases the level of participant involvement, motivation, and perceived benefit from the program.

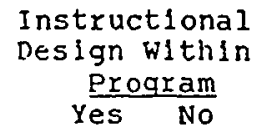

1. Team building exercises are utilized in early sessions to develop a strong cohesive and supportive learning group

2. Within each class session there is at least one of the following participatory learning instructional methods used:
A. Computer simulations
B. Role playing activities
C. Small-Group activities
D. Dlscussion of personal experlences
E. Cast studies

$\begin{array}{ll}0 & 0 \\ 0 & 0 \\ 0 & 0 \\ 0 & 0 \\ 0 & 0\end{array}$

3. Information discussed in class sessions is incorporated into courseling sessions to esilance information relevancy

4. Clients are encuuraged to share experiences and problems elicountered duxing counsel irig sosions durling class sessions to enhance information relevancy

5. Instructors develop the curricular content of thejr courses hased upon the specific business background and knowledge of clients

6. instructors incorporate the preferred learning siyles of clients into the selection of
instructional methods

$0 \quad 0$

7. Instructors involve clients in tailoring the program to meet individual participant needs through their participation in:
A. Assessing their company's problem areas 00
B. Assessing company long-term goals $\quad 0 \quad 0$
C. Assessing personal managerjal and technical abilities, skills, and knowledge $0 \quad 0$
D. Selecting the kind and depth of information
io be covered in classes 0 


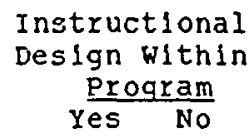

E. Selecting instructional methods used in classes 0

F. Systematically evaluating the program throughout the course of 3 tudy 
APPENDIX D

CLIENT SURVEY TOTALS 
CLIENT SURVEY TOTALS

144 respondents; 29.518 response rate

1. Do you presently own or manage a small business?

$$
\begin{aligned}
N=143 & \\
\text { Yes }=112 & (78.328) \\
\text { NO }=31 & (21.688)
\end{aligned}
$$

If Yes, how long has your company beers in business?
A. Less than 1 year
$N=95$
$=10$
B. From 1 to 3 years
C. From 3 to 5 years
$=33$
D. 5 years and above
$=33(34.74 \%)$

2. Please identify the one major business activity of either your present or proposed business:
A. Reta11
D. Construction
$=25(17.73 \%)$
C. Gerieral services
D. Wholesale
$=4(2.84 \%)$
E. Manufacturing
$=61(43.26,7)$
F. Corisulting
$(9.93 \%)$
6. Medical/Health Care $=5(3.55 \%$

$N=141$

3. When you contacted the SBDC did you have a specific problen to be adaressed?

\begin{tabular}{|c|c|c|}
\hline 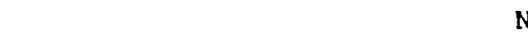 & $=114$ & \\
\hline n. Accounting/Bookkeeping & $\triangle 2$ & $(36.8 .43)$ \\
\hline 13. Business plan ereparation & 57 & $(50.002)$ \\
\hline C. Market Analys is & 37 & $(32.4 E \%)$ \\
\hline D. Financial Assistarice & 28 & $(24.56 \%)$ \\
\hline E. Management structure & 19 & $(16.678)$ \\
\hline F. Business Feasiojlity & 33 & $(28.958)$ \\
\hline G. Legal & 19 & $(16.67 \%)$ \\
\hline H. Production & $=$ & $(7.028)$ \\
\hline I. Inventory control & $=$ & $(7.028)$ \\
\hline J. Technical Assistance & $=$ & $(7.02 \%)$ \\
\hline K. Personne 1 & 14 & $(12.28 \%)$ \\
\hline L. Market1ng & 63 & $(55.26 \%)$ \\
\hline M. other & 15 & $(13.163)$ \\
\hline
\end{tabular}

$$
\begin{array}{rrr}
N=141 & \\
Y=5=114 & (80.85 t) \\
N 0=27 & (19.152)
\end{array}
$$

If yes, check all that apply: 
(Percentages are greater than 100.008 because of clients seeking assistance for multiple problems.)

4. Was your specific probiem addressed by the counselor?

$$
\begin{array}{rrr}
\text { N } & =126 \\
\text { Yes } & =116 & (92.068) \\
\text { No } & =10 & (7.948)
\end{array}
$$

5. How satisfied were you with the counseling that you received? very satisfied $5 \quad 4 \quad 3 \quad 2 \quad 1$ very unsatisfied

$$
\begin{aligned}
\mathrm{N} & =139 \\
\text { Mean } & =4.094 \\
\text { Standard Devlation } & =1.079
\end{aligned}
$$

6. Have you participated in any of the following SBDC's programs: Gretnhouse Program, Small Buslness Managewent I Program, small Bus Iness Management I I Program?

$$
\begin{array}{rrr}
N & =143 & \\
Y \in S= & 76 & (53.158) \\
\text { No } & =67 & (46.85 \%)
\end{array}
$$

If yes, which programs:

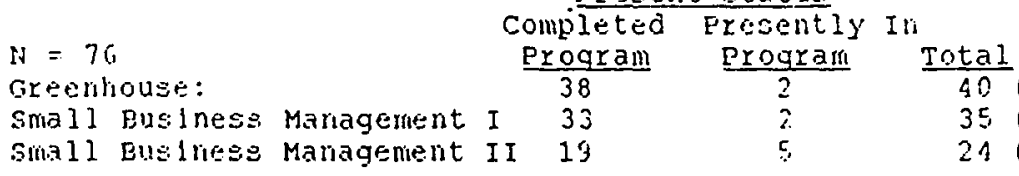
Completed Frosently in
Program Program 38

19

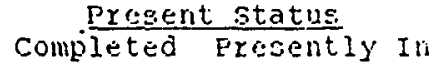

(Eercentages are greater than $100.00 \%$ because of clients participating in norc than one progran.)

7. Are there any additional subjects that should be included in the Greenhouse, and small Business Management Programs?

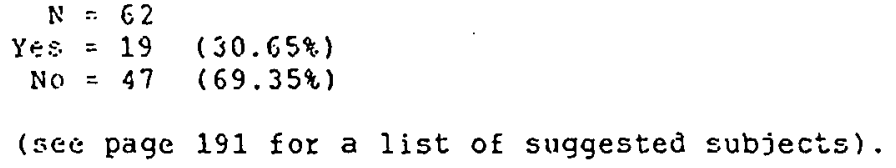

8. Are there any ways in which the counseling portion of Greenhouse and Small Business Management Programs can be 1 mproved?

$$
\begin{aligned}
& N=66 \\
& \text { YeS }=34 \quad(51.528) \\
& \text { No }=32(48.48 \%)
\end{aligned}
$$

If yes, which of the following options do you believe would improve the counseling portion of the program: 


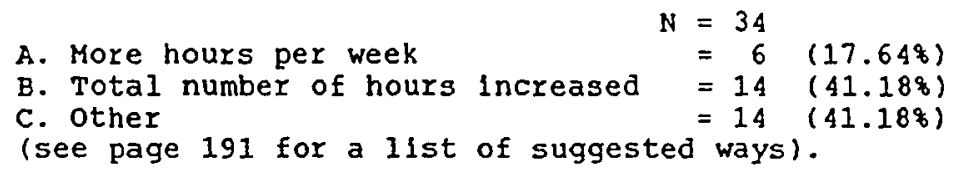

9. Are there any ways in which you would have liked to have been involved in talloring the Greenhouse and small Business Management programs to meet the specific needs of your company?

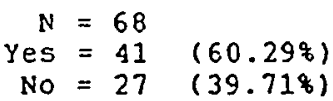

If yes, in whlch of the following waye would you like to be involved in the process:
A. Assessment of company's problems $=19$
B. Assessment of company's long-term goals $=19$
C. Assessment of personal managerial skllis
D. Selection of information to be coverea
$=19$
$=22$
E. Selection of Instructional methods
$=17$
$=19$
F. Other
$(46.348)$
$(46.348)$
$(53.668)$
$(41.468)$
$(46.348)$
(Percentages are greater thair $100.00 \%$ because of the selection of more than one optionil

$N=41$

Clierit. Evaluation of The Program

10. Counseling:

A. Counselor's knowledge of problem to be achressed was excellent

D. Counselor's suggestions were approprlate for the situation

C. Request recelved prompt assistance by counselor

D. Counselor was courteous

E. Counselor understood company'g long-term goals
Highly Highly

Aaree $5 \quad$ \& 321 Dlsaqree

$$
\begin{aligned}
N & =140 \\
\text { Mean } & =4.150 \\
\text { Standard Deviation } & =0.873 \\
\mathrm{~N} & =140 \\
\text { Mean } & =4.050 \\
\text { Standard Deviation } & =0.947 \\
\mathrm{~N} & =141 \\
\text { Mean } & =4.383 \\
\text { Standard Deviation } & =0.900 \\
\mathrm{~N} & =141 \\
\text { Mean } & =4.823 \\
\text { standard Deviation } & =0.419 \\
\mathrm{~N} & =140 \\
\text { Mean } & =4.257 \\
\text { standard Deviation } & =0.860
\end{aligned}
$$


F. Materlals provided by counselor were excellent

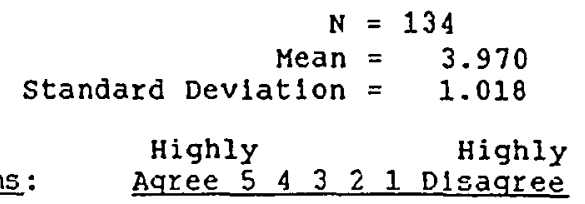

Greenhouse and Smal1 Bus iness Management Programs:

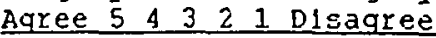
A. Information presented in classes was appropriate for company needs

B. Instructor's knowledge of subject was excellent

c. Participation in planning, coordinating, and talloring class subject matter to company needs was sufficient and appropriate

D. Courseling portion of program is appropriate

E. Ratio of class hours to counselliag hours 18 appropriate

F. Counseling hours per month should remain the same

G. Irstructional methods are effective for understanding the material

H. Sufficierit varlety of instructional methods are utilized in classes

\section{Qverall SBDC Evaluation:}

A. Persunnel were courteous

B. Materials available at the center are excellent

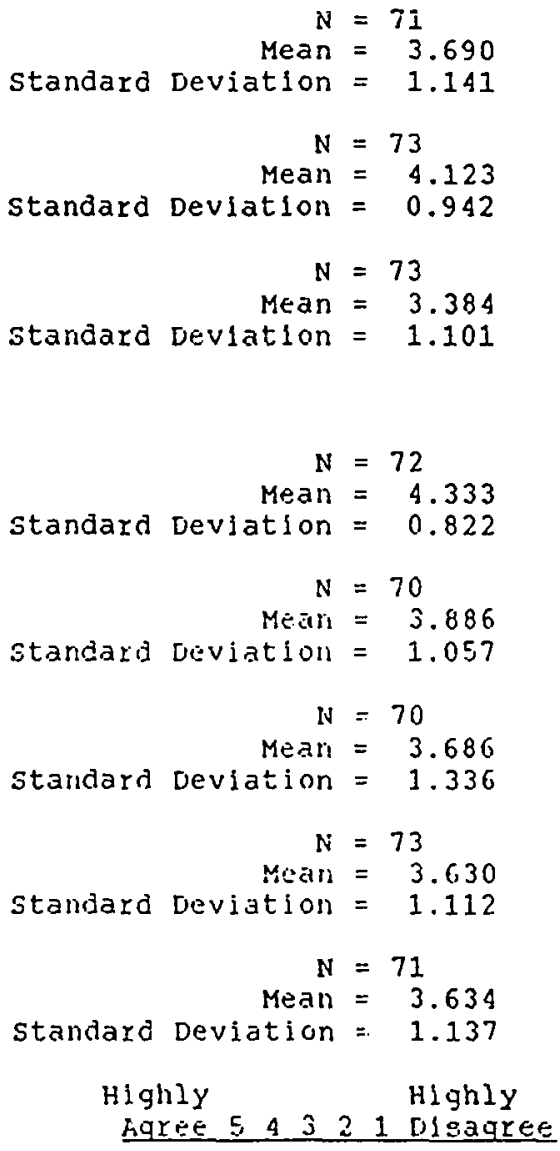



c. varlety of services avallable was sufficlent

11. The following guestion is designed to find out which frequency of class sessions you prefer:
$N=101$
A. Present schedule $=89(88.12 \%)$
B. Optional Schedule $=12(11.88 \%)$

12. In what ways do you learn best? (please check all that apply)
A. Lectures
$N=133$
B. Flims/video Tapes
$=98(73.68 \hat{i})$
C. Small Group Discusstons
$=67$
$=67$
D. Role playing
E. Computer simulations
$=27(20.30 \%)$
F. other.
- $23(17.29 \%)$

(Fercentages are greater than $100.00 \%$ because of multiple selections by respondents)

12. Jo you feel that the assistance you received at the sBDC helped you:

A. Start your business?

$$
\begin{aligned}
& \mathrm{N}=115 \\
& \text { Yes }=54(46.96 \%) \\
& \text { No } 44 \quad(38.26 \%) \\
& \text { Don't know }=17(14.78 \%)
\end{aligned}
$$

B. Stay out of financial trouble?

$$
\begin{aligned}
N & =1.20 & \\
\text { Yes } & =44 & (36.678) \\
\text { No } & =28 & (23.33 \%) \\
\text { Don't know } & =4 B & (40.008)
\end{aligned}
$$


C. Increase sales?

$$
\begin{aligned}
& N=119 \\
& \text { Yes }=39(32.778) \\
& \text { No }=37(31.098) \\
& \text { Don't know }=43(36.138)
\end{aligned}
$$

D. Increase profits?

$$
\begin{array}{rlr}
N & =118 & \\
\text { Yes } & =36 & (30.51 \%) \\
\text { No } & =39 & (33.05 \%) \\
\text { Don't know } & =43 & (36.44 \%)
\end{array}
$$

E. Increase the number of employees?

$$
\begin{array}{rlr}
N & =107 & \\
\text { Yes } & =7 & (6.54 \%) \\
\text { No } & =57 & (53.27 \%) \\
\text { Don't know } & =43 & (40.19 \%)
\end{array}
$$

14. To assist us in making our instructional courses more informative and enjoyable for you, please rate each of the Following options by distributing ten (10) points among the four choices to indicate how intensely you prefer each choice. please always use all ten points. You may use zeros for those options that are not important to you.

Eximple: In class, I prefer that the instructor encourages clients to:

A. share thelr feelings

c. take note:

B. llsten quletly

D. ask questions 5

1. In class, I prefer an instructor to emphasizc:

$\begin{array}{lrl}\text { A. client-centered discussions } & =127 \\ \text { Is. lectures } & =263 & (21.728) \\ \text { C. problen-solving activities } & =255 & (21.064) \\ \text { D. application activitjes } & =362 & (29.898) \\ \quad \text { Total } & =\frac{331}{211}(100.00 \%)\end{array}$

2. In class, I prefer an instructor to emphasize:

A. theories

B. skills

C. attitudes

D. perspectives
Total 
3. Instructore should see their prlmary role in class as:

$\mathrm{N}=127$

A. organizing what takes place in class= 314 (24.968)

B. connecting major ldeas for clients $=463$ (36.818)

C. encouraging clients to participate $=251$ (19.958)

D. listening to clients $=230 \quad(18.28 \%)$

Total

$=1 \overline{258}(1 \overline{00.008})$

4. In a class, I prefer to be involved in:
A. learning about theories, principles, and concepts
$N=128$
$=253(20.558)$
B. learning how to independently evaluate and apply information discussed in class
$=507(41.198)$
C. expressing my feeling regarding varlous theorles, princlples, and concepts
D. observing carefully how theories, principles, and concepts have been applied
Total
$=\frac{336}{231}(27.29 \%)$
$=1 \overline{231}(100.00 \%)$

5. In class, I prefer instructors who empirasize:
A. small group discussions
$N=128$
B. free expression of feelings
$=323(26.282)$
C. careful organization of matexial
$=223(16.14 \%)$
D. time for clients to think independently
$\operatorname{Tota} 1$
$=\frac{237}{259}\left(1 \frac{19.298)}{100.00)}\right.$
$=1224(100.00 \%)$

6. I prefer ari instructor who is $a(n)$ :
A. expert $\mathrm{N}=129$
$=435(35.05 \%)$
B. scholar $=147(11.85 \%)$
C. advisor $=468(37.71 \%)$
r. fritend $=191$ (15.394)
Total $=1 \overline{241}(100.009)$ 
7. I prefer an instructor who is $a(n)$ :
A. coach
B. group facliltator
C. director
D. interpreter of information
$\mathbf{N}=129$
$=276(22.248)$
$235(18.948)$
$(20.318)$
Total
$=\frac{478}{241}(138.518)$
$=1 \overline{241}(100.008)$

\section{ABOUT THE SBDC CLIENT}

15. Your Age:

\begin{tabular}{|c|c|c|c|c|c|}
\hline & & & & & \\
\hline & Und & er 21 & & 3 & (2. \\
\hline & 21 & -29 & $=$ & 7 & $(5.048)$ \\
\hline C & 30 & 39 & $=$ & 37 & $(26.62 \%)$ \\
\hline ए & 40 & -49 & $=$ & 63 & $(45.328)$ \\
\hline E & 50 & -59 & - & 26 & $(18.718)$ \\
\hline $\mathrm{F}$ & 60 & or over & $=$ & 3 & $(2.168)$ \\
\hline
\end{tabular}

16. Gender of owner or generai manager:

$\begin{array}{rrrr} & N & =138 & \\ \text { A. Male } & =58 & (42.03 \%) \\ \text { B. Female } & =73 & (52.90 \%) \\ \text { C. Eoth/Eartiershlp } & =7 & (5.07 \%)\end{array}$

3.7. Your edncationai background:

$\begin{array}{lrlr}N & =140 \\ \text { A. High school or less } & =17(12.14 \%) \\ \text { B. Some college } & =53(37.86 \%) \\ \text { C. College graduate } & =22(15.71 \%) \\ \text { D. Some gost-graduate work } & =27(19.29 \%) \\ \text { E. Post-graduate degree } & =21 & (15.00 \%)\end{array}$

18. Number of Ernployees:

\begin{tabular}{|c|c|c|}
\hline $\mathbf{N}$ & $=1.39$ & \\
\hline A. Haven't started the company & 25 & $(17.994)$ \\
\hline B. only owres (s) employed in compary & 56 & $(40.258)$ \\
\hline C. 1 - 5 employees & 38 & $(27.348)$ \\
\hline D. $6-10$ employces & 6 & $(4.328)$ \\
\hline E. $11-24$ eimployees & 7 & $(5.04 \%)$ \\
\hline F. 25 employees and above & 7 & $(5.04 \%)$ \\
\hline
\end{tabular}


19. Dollar value of company asgets:

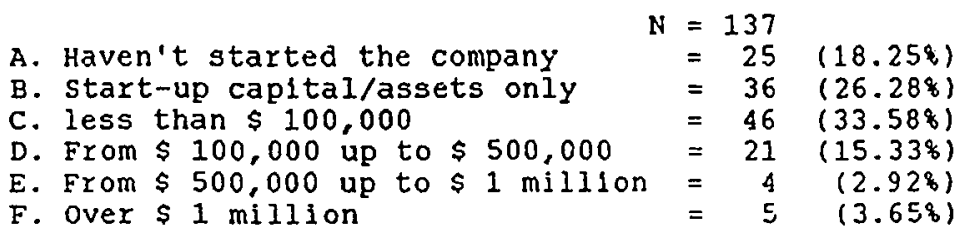

20. Annual sales volume:
A. Haven't started the company
$N=134$
B. Less than $\$ 25,000$
$=\hat{24}(17.31 \hat{*})$
C. Betwien $\$ 25,000$ and $\$ 100,000$
$=42(31.34 \%)$
$=30(22.398)$
D. Between $\$ 100,000$ and $\$ 250,000=16$ (11.94\%)
E. Between $\$ 250,000$ and $\$ 500,000=8(5.97 \%)$
F. $\$ 500,000$ and above
$=14(10.45 \%)$ 
COMMENTS RELATED TO SPECIFIC QUESTIONS

1. Question 7 - Additional subjects deslred:

(The following are individual responses)

A. Greenhouse:

1. Famlly involvement in Business

2. Problem solving using real examples

3. More in-depth coverage of subjects

4. How to do feasibility studies

5. More specific on laws and rules

B. SBM I and I :

1. Communication Skills

2. Time Management

3. Stress Management

4. Planning for future growth

5. More on intarigibles - emotlons, personal goals

6. More employee related issues ana management

7. Computers in business

8. Use of video communications - marketing, training

9. Working with difficult clients

10. More on analyzing numbers

2. Question 8 - Improving counseling portion of Greenhouse and SBM program:

(The followling are individual responses except where labeled)

1. Improvement of the resource library - licreasing resiurces

2. Four responses requesting greater in-depth coverage of topics:

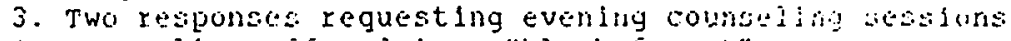

4. Counzellng offered in a "block format"

5. cluser integration between counseior ano program activities

6 . Better defined topics with expert speakers 
APPENDIX E

TOTAL RESPONSE PROFILE OF SHORT-TERM COUNSELING AND SMALL BUSINESS MANAGEMENT PROGRAMS DIMENSION VARIABLES 
TOTAL RESPONSE PROFILE OF SHORT-TERM COUNSELING AND SMALL BUSINESS MANAGEMENT PROGRAMS DIMENSION VARIABLES

\section{Short-term Counseling Program Dimension Variables}

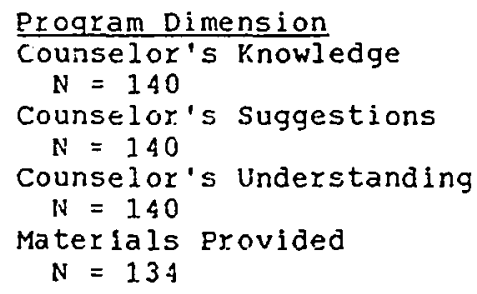

\begin{tabular}{ccccc}
5 & Response Rate \\
\hline 58 & 4 & 3 & 2 & 1 \\
41.48 & $36.4 \%$ & $18.6 \%$ & $2.9 q$ & $.7 \%$ \\
51 & 57 & 23 & 6 & 3 \\
36.48 & $40.7 \%$ & $16.4 \%$ & 4.38 & $2.1 \%$ \\
68 & 45 & 23 & 3 & 1 \\
$48.6 \%$ & $32.1 \%$ & $16.4 \%$ & $2.1 \%$ & .78 \\
53 & 36 & $35 \%$ & 8 & 2 \\
39.68 & 26.38 & $26.1 \%$ & $6.0 \%$ & 1.58
\end{tabular}

Greerhouse/Small Business Management Program Dimerision Variables

Program Dinension Appropriate Information $\mathrm{N}=71$

Instzuctor's know]edge $\mathrm{N}=73$

C] ient Participlotion $N=73$

Covineling portion $N=72$

Clas: Ratio $\mathrm{N}=70$

Counseling Hours $N=70$

Instructional Methuás Effectiveriess $N=73$

Varjety of Instructional Methons $N=71$

\begin{tabular}{|c|c|c|c|c|}
\hline 5 & Respor & $\begin{array}{c}\text { Rate } \\
3\end{array}$ & 2 & 1 \\
\hline 23 & 16 & 21 & 9 & $\frac{1}{2}$ \\
\hline 32.48 & $22.5 \%$ & 29.68 & 12.73 & 2.88 \\
\hline 32 & 22 & 16 & 2 & a \\
\hline $13.9 \%$ & $30.1 \%$ & 21.98 & $2.7 \%$, & 1.48 \\
\hline 15 & 15 & 29 & 11 & ? \\
\hline 20.63 & 20.68 & $30.7 \%$ & $15.1 \%$ & 4.18 \\
\hline 40 & 16 & 16 & 0 & 0 \\
\hline $55.6 \&$ & 22.28 & $22.2 \%$ & $0.0 \%$ & $0.0 \%$ \\
\hline 26 & 18 & 19 & 6 & 1 \\
\hline 37.18 & 25.78 & $27.1 \%$ & 8.63 & 1.48 \\
\hline 28 & 13 & 13 & $1]$ & 5 \\
\hline $40.0 \%$ & $18.6 \%$ & $18.6 \%$ & $15.7 \%$ & 7.1 \\
\hline 22 & 15 & 24 & 11 & 1 \\
\hline 30.19 & $20.6 \%$ & 32.38 & 15.13 & 42 \\
\hline 22 & 15 & 21 & 12 & \\
\hline 31.08 & $21.1 \%$ & $29.6 \%$ & 16.69 & 1.48 \\
\hline
\end{tabular}


APPENDIX F

COMPARISON OF CLIENTS AND CENTER PERSONNEL RESPONSES

TO QUESTIONS REGARDING PROGRAM INSTRUCTIONAL AND

CURRICULAR DESIGN ISSUES 


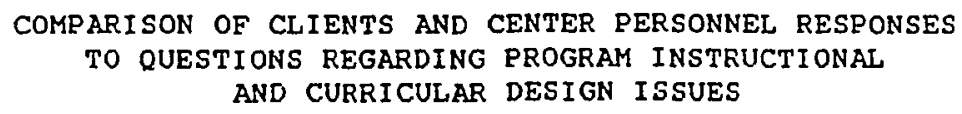

The following table compares the responses of center clients and the short-term counselors to the instructional and curricular issues contained in the seven sub-questions of question 13 in the client program evaluation survey (see Appendix A). Respondents were asked to distribute 10 points among the four options of each of the following sub-questions.

\section{Sub-question}

$$
\frac{\text { Client }}{\text { Perceptions }}
$$

A. cliert-centered discussions 263 (21.7\&)

B. lectures 255 (21.10)

C. problem-solving actlvities 362 (29.9:)

D. application activities Total

$331(27.38)$

$\frac{331}{1211}(100.08)$

$$
N=128
$$

2. In class, I prefer an instructor to emphasize:
A. theories
A. theories
B. skills
C. attitudes
$444 \quad(36.5 \%)$
$244 \quad(20.04)$
D. perspectives
Total
$12(17.4 \%)$
$27 \quad(39.1 \%)$
10 (14.5q)
$\frac{20}{63} \frac{(29.02)}{(100.02)}$

$15 \quad(21.4 \%)$

$\frac{15}{70}(100.0 \%)$

$N=8$
Center Personnel Perceptions $N=8$

$19 \quad(27.18)$

$17 \quad(24.48)$

$19(27.1 \%)$

$N=127$

$N=8$

3. Inscructors should gee their prlmary role ln class as:

A. organizing what takes piace in ciass

B. connecting mafor ideas for cijarits

c. encouraging clients to participate

D. Iistening to clients

Total
$25 \quad(35.8 \%)$

$22(31.4 \%)$

$11(15.7 \%)$

$1.2 \quad(17.2 q)$

$\frac{12}{70}(100.08)$ 
$N=128$

4. In a class, I prefer to be Involved in:

A. learning about theories, principles, and corcepts

$253(20.6 \%)$

B. learning how to independently evaluate and apply Information discussed in class

c. expressing my feeling regarding varlous theorles, principles, and concepts

$135(11.08)$

D. observing carefully how theorles, princlples, and coricepts have been applied $\underline{336}$ (27.2\%) Total $1 \frac{336}{231}(100.08)$

$\mathrm{N}=128$

5. In class, I prefer instructors who emphas lze:
A. smäll group discussions
$323\left(26.3^{3}\right)$

B. frete expression of feelings 223 (18.1\%)

C. careful organization of material

5. time for clients to thint: indeperidently

$$
\text { Total } \quad \frac{237}{229}\left(\frac{(39.39)}{100.018)}\right.
$$

$N=129$

6. I prefer sin inetructor who is $a(n)$ :
A. e:pert
E. scholar
C. advisor
D. friend Total

7. I prefer an listructor who is a(n):
A. coach
B. grudi facjitator
c. alrector
D. Interpreter of information Total

$N=6$

$13(18.68)$

$36 \quad(51.48)$

$8 \quad(11.48)$

$$
\begin{aligned}
& \frac{13}{70} \frac{(18.68)}{(100.08)} \\
& N=8 \\
& 17 \quad(24.6 q) \\
& 14 \quad(20.48) \\
& 21 \quad(30.48) \\
& \frac{17}{15} \quad \frac{(24.68)}{100.08)} \\
& N=8 \\
& 18 \quad(21.48) \\
& 2 \quad(2.98) \\
& 51 \quad(58.68) \\
& \frac{12}{70} \quad \frac{(17.18)}{(100.08)} \\
& N=8 \\
& 36 \quad(51.58) \\
& 18 \quad(25.78) \\
& 4 \quad(5.78) \\
& \frac{12}{70} \frac{(17.18)}{(100.08)}
\end{aligned}
$$


4. In a class, I prefer to be Involved in

$N=128$

$\mathbf{N}=8$

A. learning about theories. principles, and concepts

$253(20.6 \%)$

$13(18.68)$

B. learning how to Independently evaluate and apply information discussed in class

$507(41.28)$

$36(51.48)$

C. expressing my feeling regarding various theories. principles, and concepts

$135(11.08)$

$8 \quad(11.48)$

D. observing carefully how theorles, princlples, and concepts have been applied Total

$\frac{336}{231}(27.2 q)$ $1 \frac{335}{231}(100.03)$

$\frac{13}{70} \frac{(18.62)}{(100.08)}$ $\frac{13}{70}(100.0 \%)$

$N=128$

$\mathbf{N}=8$

5. In class, I prefer instructors who eriphasize:
i. small group discussions
$323(26.34)$

E. Free expression of feelings 22.3 (18.17)

$17 \quad(24.62)$

C. careful organization of material

$446(36.3 q)$

$14(20.48)$

0. time for clients to think indeporidentiy

$$
\text { Total } \frac{237}{1223}\left(\frac{19.3 \%)}{100.0 \%)}\right.
$$

$21(30.4 \%)$

$\frac{17}{69} \frac{(24.6 \%)}{(100.08)}$

$N=129$

‥ T prefes sn lnetriogor who is a(n):
A. erpert
B. Echolar
C. advisor
i. friend
Total

435 (35.1.)

147 (11.9\%)

$468 \quad(37.79)$

$\frac{193}{241}(15.3 \%)$

$1 \overline{241}(100.04)$

$\mathrm{N}=129$

7. I prefer an listructor who is $a(n)$ :
i. $\cos \mathrm{ch}$
z. group facilitator
276
c. airector
$\left(22.3_{v}^{\circ}\right)$
ij. interpreter
$235\left(13.00^{\circ} \mathrm{\circ}\right)$
$1241 .(100.04)$

$6,9(100.02)$

$N=8$

15 (21.48.)

$2 \quad(2.98)$

$41 \quad(58.68)$

$\frac{12}{70} \frac{(17.1 \%)}{(100.0 \%)}$

$70(100.0 \%)$

$N=\varepsilon$

$\begin{array}{rr}36 & (51.58) \\ 16 & (25.7 \%) \\ 4 & (5.78) \\ \frac{12}{70} & \frac{(17.18)}{(100.08)}\end{array}$ 
APPENDIX G

SMALL BUSINESS DEVELOPMENT CENTER RESEARCH 
SMALL BUSINESS DEVELOPMENT CENTER RESEARCH

A 1982 study conducted by Chrisman, Nelson, Hoy, and Robinson (1985) sought to measure the tax revenue contributions made by the Georgia and South Carolina SBDC programs. In the fall of 1982, a survey was conducted by telephone and mail of 583 Georgia small businesses which received in-depth counseling between october 1,1980 and July 31, 1981 (1985, p. 3). A 25.7 percent response rate ( 84 responses) was obtained in the Georgia study. Concurrently, a similar survey was conducted in South Carolina among 50 of the 100 small business that had recelved SBDC asslstance $(1985$, p. 3). A 38 percent response rate (19 responses) was obtained in the south carolina study. In the survey, owners were asked the level of their gross sales, number of employees, and net income before and after SBDC assistance was recelved. The difference between the before and after assistance figures for each category was calculated. The researchers assumed that increases in these three categories (number of empjoyees, gross sales, and net incomel were attributable to the assistance received from the progzam.

The program's contribution to Georgia's tax revenues was calculated usling the followling formulas:

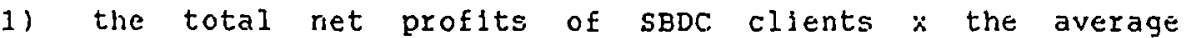
corporate lncome ta: rate paid by all Georeia corporations plus

2) the total gross sales of sBDC clients $x$ the state sales tax rate plus:

3) the net increase in SBDC client employecs $\%$ Average Georgia imployee incame generated by employutut ("hage and salary income/total personal income") $\because$ the state personal income tär räte (Chrisman, 1985, p. 4).

The rosults of these calculations were compared to the experience of a "control group" of businesses not receiving sBac assistance icheismin, 1985, p. 4). This control grouly developed by the rescarchers was comprised of statewide averages of sales, net profits, and numbers of employees for all companies within the stati. The results of these comparisons can be seen in Table III.

Table III.

Comparison of sBDC Cllerts and control group nverage Fercent Average Percent Iricremental change change Eercent Charige

5BDC Cllents All Buslresseo Between Groupe

\begin{tabular}{|c|c|c|c|}
\hline Georgla & & & \\
\hline sales & $23.2 \&$ & $4.0 \%$ & $21.2 \&$ \\
\hline Einployees & 8.72 & $(1,1) \%$ & 3.69 \\
\hline NEt Prof & $25.1 \%$ & $7.1 \&$ & $16.0 \%$ \\
\hline South Carolina & & & \\
\hline sales & $31.4 \%$ & $(3.5) \%$ & 37.98 \\
\hline Elipl loyes & 9.88 & $(1.8) \&$ & $11.6 \%$ \\
\hline Net Prof it & $30.9 \%$ & $(3.5) 8$ & 34.4 \\
\hline
\end{tabular}

(source: Chrisman, 1385, p. 7 ) 
The profected aggregate change for all Georgia SBDC clients 1700 cllents) during 1982, was an 1ncrease of $\$ 188,162,590$ in sales, 2492 new Jobs, and $\$ 6,648,005$ in net profits (Chrisman, 1985, p. 7). Chrisman estimated that the Georgla SBDC clients generated $\$ 6,600,000$ in state tax revenues and $\$ 3,300,000$ in federal tax revenues, which compares favorably with the $\$ 1,010,000$ in state and federal funds that were expended for the SBDC programs in 1980-81 (Chrisman, 1985, p. 9). The projected aggregate change for all South Carolina SBDC clients ( 100 clients) during 1982, was an increase of $\$ 22,428,765$ in sales, 97 new jobs, and $\$ 1,354,637$ in net profits (Chrisman, 1985, p. 9). Chrisman estimated that the south Carolina SBDC clients generated $\$ 1,042,818$ in state tax revenues and $\$ 535,897$ in federal tax revenues, in comparison to a total of $\$ 400,000$ in federal and state funds that were expended during 1980-1981 (Chrisman, 1985, p. $10)$.

Elstrott (1987) criticized this study because of the composition of the control group chosen by the researchers. It included both large businesses and older small businesses that were less volatile to increased rates of growth in sales, employment, and profits (Elstrott, 1987, p. 70). Elstrott suggested that the relative small sample sizes that were obtained would signiflcantly okew the results of the study in favor of the SBDC clients (Elstrott, 1987, p. 70). To overcome this problem, Elstrott recommended the development of matched control groups contalning only small busiresses (1987, p. 71). In response to Elstrott's criticlsm, Chrisman et al. (1987) supported the resuits of their stuay by citing a study by pelham \{1305\} of the Iow. sBDC program which suggested there was no signlficint difference in growth volatlilty between se[jc rilents and non-clierits (Chrisman, 1987, p. 73). Chrisman a) so suggested that thejr senc cilent. sample had also contajned solie large-alacd small basinesses that would tend to counterbalancs the large businesses contalnes within the control group (1987, f. 74 ).

Pelham's (1985) comprehensive study of the Iowa SREC program was in direct response to the suggested dismantlement of the lowa program called for by the National Federation of Independent Business (NFIB). The NFIB criticisms of the program were: 1 ) funds would be more effectively used in the form of capital made available to small businnsses, 2) funds; would be used more cost effectively if expended in libe small Business Administration small Business Institute and Servico corps of Retired Executives programs, 3) Academics knew very little that was applicable to small business needs (Pelham, 1985, $p$. 4.1-42). An limportant component of Felhari's study was a series of surveys of Iowa SBDC clients taken in 1983, 1984, and 1985. In a 1983 mail survey of 624 SBDC clients $(38.4 \%$ response rate) for the [Nerlod of 1982 and 1983, Pelham found that the seDc cllents created 796 new jobs, an increase of 20.3 percent compared to the .1 percent decrease for all Iowan companies pelham, 1985, p. 46). Peinam found from two additional surveys taken in 1984 (clients of october 1983 June 1984$)$ and 1985 (clients of June 1984 - October 1984) the average SBDC client growth in employment was 6.1 percent, in comparison to 2.1 percent growth for all Iowan companies (Pelham, 1985 , p. 47). Felham estimates that for 1984 the tax revenues 
generated by clients of the program were $\$ 388,339$, In comparison to $\$ 82,000$ in funds expended on the program $(1985$, p. 48$)$.

The only major Independent study of the oregon small Business Development Center Network (OSBDCN) was conducted by owens (1985) in 1985. The study consisted of a mall survey to all 990 SBDC clients that had recelved assistance, and each of the 20 SBDC center directors. A client response rate of 30 percent (295 responses) was obtained (Owens, 1985, p. 30). The major findings of the survey were:

. Three-quarters of the SBDC cllents were $30-50$ years old

. Flety-orie percent of cllents were women

- Ore-third of clients were in service industries

. One-third of clients were in wholesale or retail trade

- One-third of clients were in manufacturing

. Cllents reported an average of 2.9 full-time employees

2.4 part-t lime employees

Clients had operated an average of three years

. Clients sought assistance in: business management $45^{\circ}$ Marketing/advertising $41 \%$ business plan preparation $40 \%$

. Clients given assistance in: starting business information $41 \%$ business plan preparation 38 ? marketing/advertising 368 flnarictal maragement. $27 \%$,

. Twerity-five cllente (8.5 percent) reportec a total Increase of 41 emrloyees and 10 (3.4 percent) clients reported a total diczease of 15 engloyees

. Forty-eight percent of clients rated the counseling as

atrenty satisfying and only 12 percent were dissatisfied

(Suturce: owers, 1385, p. $32-41$ ) 
APPENDIX H

SUMMARY OF CLACKAMAS CENTER INTERVIEWS 
SUMMARY OF CLACKAMAS CENTER INTERVIEWS

The following surumary is of a series of in-depth interviews that was conducted at the Clackamas Center between June $10-13,1990$. The group of interviewees consisted of all individuals directly involved in the short-term counseling ( 5 counselors) and Greenhouse/Small Business Management Programs ( 3 instructors).

1. How do you see your role in the Greenhouse and small Business Management Programs?

The initial response of all interviewees was to answer this question in terms of their own individual job description, as a counselor or instructor/counselor. However, as respondents began describing their individual interactions with clients, they all presented a consistent picture that is aptly described by the following response: "...as a coach who helps the client learn how to solve problems, rather than solving the client's problem lite a consultant." Thus lnterviewees saw thelr role as helping the elient discover for themselves whether the business idea was feasible or how to solve an organizational challenge.

2. When an individual with a new idea for a business, comes to your office for the first time what do you do?

The initial step in the assistance process is to have new clichits complete form 1086. This is a short questionialre which asts the foilowing guestions:

1. Rxe you current]y: starting a business?, buying a busthess?, lid bus lness?, how many yeare?, and how many employees?

2. What kind of business: retail, wholesale, manutacturing, construction, service, other?

3. Type of business: sole proprietorship, partnership, corporation.

1. Do you need help with: business startup/purchase, locating, financing, marlieting, personrel, recordkeeping, business plan development, growth/expansion, finding resources, other?

5. If you are buyirig or already own a business, do you have: a recent balance sheet, a proflt and loss statement, tax statements for the last three years, an accountant, value of inventory, fixtures and equipment, an attorney? 
After initlaliy reviewing form 1086 with the client, all interviewees mentioned that the major need was to ascertain if the individual would make a good business owner and whether the business ldea was viable. Respondents sald that they asked questions to ascertain the following information:

1. Individual's Personal Characteristics: the person's temperament, risk assuming characteristics, personal finances and security needs, and personal short-term and long-term goals.

2. Business Feasibility: a business purpose analysis, customer analysis, competitor analysis, product analysis, sales and financial projections.

Fil respondents stated that they assisted the clients to determine for themselves whether or not to start the business. Everyone saw their role as ore of "... walking the client through the rumbers, but never recommending whether or not to start the business."

Corisistently respondents mentioneo that the Greenhouse program was not for everyone. Commonly mentioned factors that interviewees stated they considered before recommeriding the program to clients were:

. Feasibility of the business idea

- Compatibility with personal goals and time shedules

- Appropriateness of selected alternative workshops

- Frior business knowledge and skills

. Whether the individual would be willjug to devote the needed time and energy to the program.

3. If the lradividual coming to your office is the owner or manager of an actusily opersting bugluess, what $a b$ jou do?

Interviewees stated that in their eyerience, nost business owrics sebl arsistance for very speciflo businese problerus. some owhers have difflculty articulating the problem, but with asslstance from the counselor they are able to process the information and diagnose the situation. Fespondints mentioned that analyzing the following areas are particularly helpful in the diagnosis process:

. Compary's financial history

- Company's capltal etructure

. Owner's management knowledge and 3 r.11ls

. Owner's long-term personal and company giols

-Famly issues/communication lssues lf famlly owried busines:

Respondents utilize much of the same criteria in deciding whether to recorumend the snall Buglness Managewent Progran to clients as they use for the Greenhouse Program. Counselurs said they especially look for evidence of high levels of readiness, 
discipline, and commitment on the part of the business owner before recommending the SBM program. Interviewees sald that they quite often recommended speciflc workshops and short-term counselling to clients that are seeking assistance for specific business problems.

4. Are there specific factors that you believe determine whether a business will be successful or fall?

The chief factor that determines whether a business succeeds or fails, cited by all respondents, was the level of determination of the smali business owrer. other important factors mentioned were the level of management, planning, financial, and marketing skills and systems that exist within a company.

5. Do you teach any of the Greenhouse or Small Eusluess Management courses?

of the three instructors, one has primary teaching responsibility for the Greerhouse prograim, and two have prlmary teachirig responsibility for the smalj Eusiress Management Programs. Counselor are asked to teach specific course sessions depending on their business knowledge and skills.

6. What should individuals specifically know or be able to do after they have completed the Greenhouge and smil Easiness Maragement: Eruigina?

After completing the Grechlouse roggra, clients should how whether they have a viable buslirse jaba. If theil business is feasible, they will have developed a complete business plan and a knowledge of informational resources that are available to them.

After comrleting the small Business Hangeneat program, cljents should be able to find solutions to theix company's problems, know more in-depth records analysis, how to manage Luesincss: growth, how to deverng appropriale personal and buslifess related goals, and the bruadentng and perfecting of their managerial skllis and knowledge.

7. What materials do you use during the instructional and counseling sesslone?

Prjor buslness experlence, and any materials cilents brought with them were the major materlals that respondents saja they used during the initial short-term counseling session. The Clackamas center has a library of business related materials which could be used in specific cases. At the time of this study, instructor developed workbooks were being utilized in both thic Greenhouse and small Business Management clase sessions. Materials utilized during counseling sessions depends on the particular issue or problem the client wants to discuss. 
8. Are there any of the toplc areas that you feel should be speclelcally emphaslzed?

Two major topic areas mention by respondents were customer needs and personnel policies.

9. Are there business related factors that determine what is taught in the Iristructional and/or counseling sessions?

No specific business related factors are used by
ingtructorg to determine the Informational content of class
and/or courseling sessions. clients are asted what specific
topics they would like to cover in class sessions. Responderits
said the other factor they consider is the clients experience
and level of technlcal sophistication. The counseling sessions
are designed around the speciflc netds of the Individual client.

10. Are the counseling sessions of the Greenhouse ard small Business Management Frograns specificaliy related to the iopics discussed during the instructional sessions?

The focus of the counseling sesslons at the beginning of the program are closely related to what is telug taught in the class zesislons. however, the experierice of the rospondents has been that as the program progresses, the focus of the couriseling sessions diverges from the instructional program and becomes sure focused on current business problems.

11. During the instructional sessions, oo you usf any of the [ol]owig fnetructional luethods:
h. Lectures: Yes, Jecturing was atilizea by all three Instructors for a portion of each ciassroom sesslon.
B. Computer simulations: No this method was noi used.
c. Sole playing: one instructor used this mithod oftem, one incticuctor occaslonally, and one instructor did not use this retiod.
D. Small Group nctivities: Yes, all threc instructors said they hesia thls eacli clase session.
E. Discussion of personal experiences: yes, all three
lnstructors old they often used this method.
F. Case studies: Yes, all three instructors said they often usea this method.
G. ollier: None were mentioned.

12. Are clients involved in selecting and evaluating the instructional methods that are used during class or counseling sessions? 
clients are not dixectly involved in the selection and evaluation of the instructional methods used during class sesslons. However, all respondents mentioned that clients were able to participate to some degree in these activities because of the participatory nature of the instructional program.

13. Are clients involved in selecting the level of information that will be covered during the instructional classes or counseling sessions?

No, clients are not involved in this process. Respondents said they made this decision based upon their own intuition, and the communication they had with clients in class and courseling sessions.

14. Are cijents irivolved in evaluating the Greerhouse and small Eusiness Managenent programs?

C]ients are asked for their evaluation of the instructor and class materials when they have completed the prograrn. All three instructors sald that they did not see the results of that evaluation. All three instructors said that they conduct frequent informal evaluation sessions throughout the program so that any adjustments can be made if necessary.

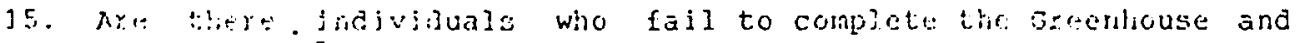
EEM piograns?

1.] threr: respondents sald that very few cllents who start

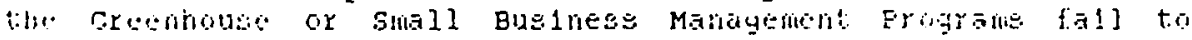
f. In $1: 1$. .

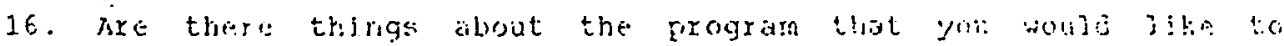
charige?

Jtems mentioned were:

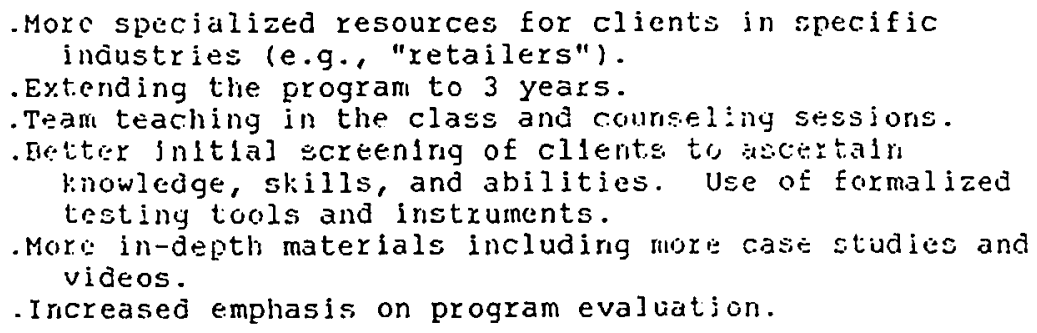


APPENDIX I.

GREENHOUSE AND SMALL BUSINESS MANAGEMENT CURRICULUM 
GREENHOUSE AND SMALL BUSINESS MANAGEMENT CURRICULUM

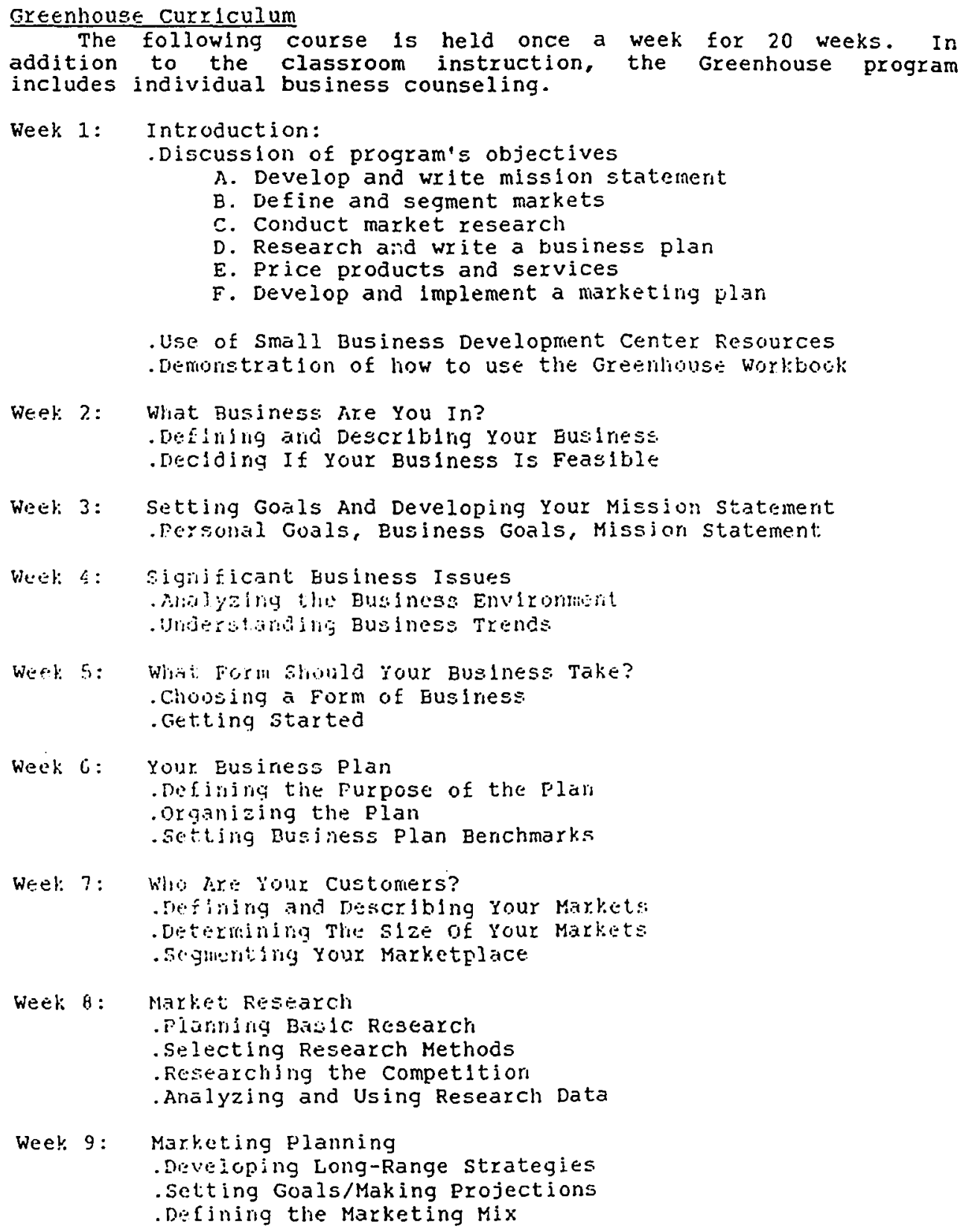

Week 8: Market Research

- Plámila Basic Research

- Selecting Research Methods

Weet. 9: Marketing planning

Dieveioping Long-Range strategies Selting Goals/Making Projections . Dofining the Marketing Mix 


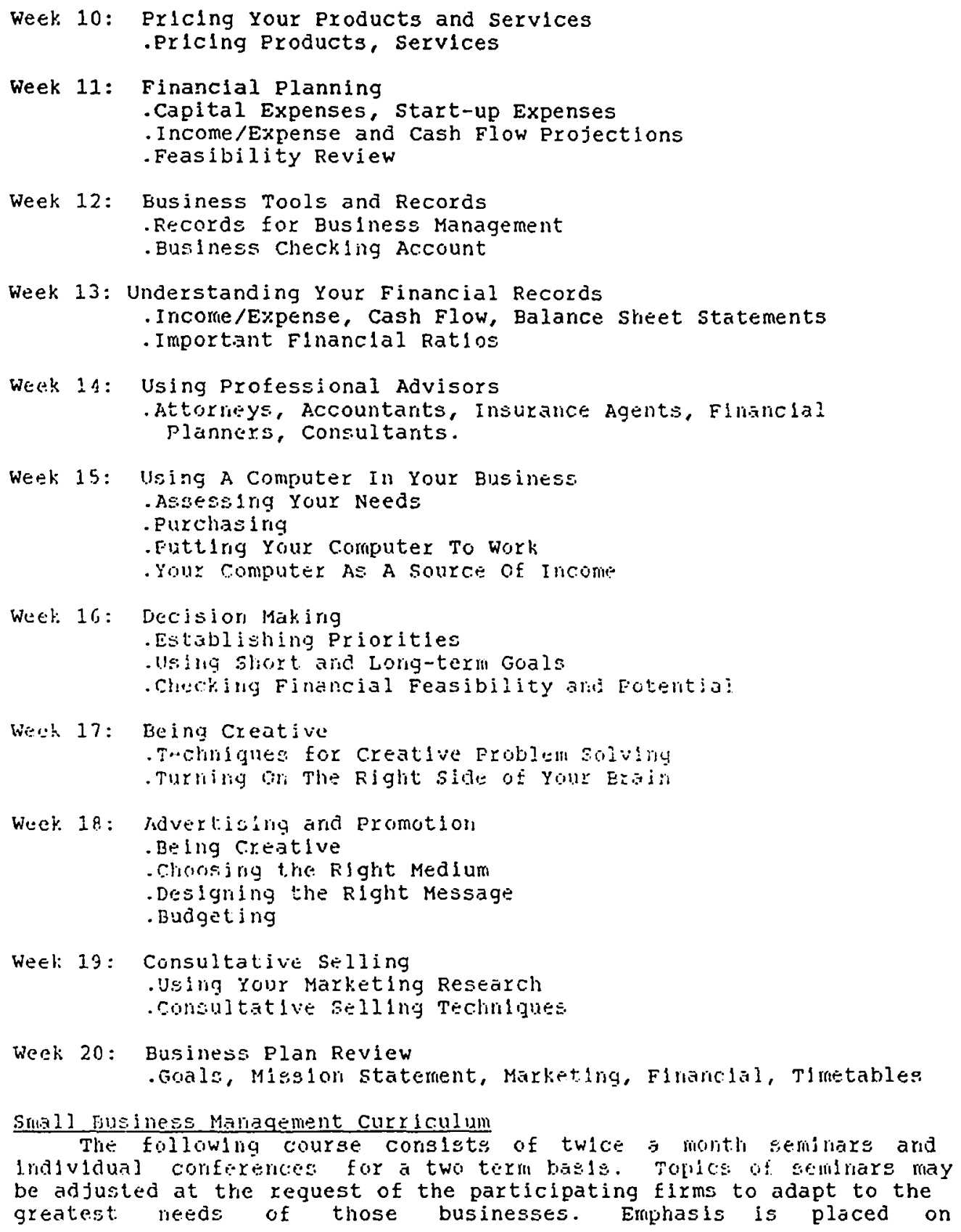

Week 20: Business Plan Review

-Goals, Misglon staterient, Marketing, Flnanclal, Tintableg

Sruald Gusiness Mariagement Cury lculum The following course consiete of twice g molith seminars and individual confixences for a two term basls. Topics of sembars may be adjusted at the request of the participating firms to adapt to the greatest needs of those businesses. Emphasis is placed on 
establishing and keeping good records as a basis to accomplish the following goals:

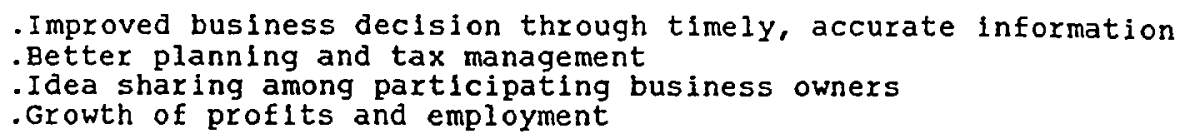

Proposed Topics For Term I: Small Business Management I

1. Do you Run Your Business of Does Your Business Run You? - Define your business and its customers

. Set goals for growth and direction of your business

. Present marketing and financial tools available

2. How Well Do Your Records Talk to You?

. Lool: at current records

. Understand basics of information in the records

Inprove the records--declsion link.

3. Do Financial Records Help In Business Decisions?

.obtain recent stateruent, if avajlable

- IGenlify elements of financial statements

- Discuss use of statements for business decisions

4. Finatucial Analysis

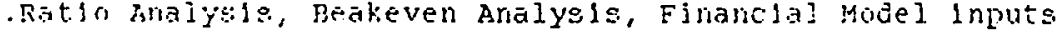

5. Contininisotion Shi] ls

. Fviluste the offectivenese of ycir mostoges;

interpiesobial stills

- Techigues to improve effectiveness

6. Marbeting and How to Increase sales

- Evaluate current marketing activities

Explore new narketing approaches

. Deveion a marketing plan

7. Enjoicyes Law

- Independerit contract or Employee

. Current Federal ano state regulations

- Persominel hanuals

8. Plan to Pay the Minimum Tä

. consider Year end proflt and tä position

. Frepare to clise the books

- Flan yoar end tar activities

9. Obtaining capital

. Identify sources of funding

Luan parekaging 
10. Stress and Time Management/Presentation of $5 B M$ II contents - Develop time management technlques

- Learn stress reduction techniques

\section{Topics For Term II: Small Business Management II}

11. Strategic Planning

- ReVlew and assess accomplishments from the past term

. What is strateglc Planning

. The planning process

12. The harketing concept

- A Ps of marketing

- Market research

- Relatlonshlp between marketing and financial issues

- Customer service

13. Do You Need a Marketing Budget?

. Buageting methods, Forecasting Methods, Brtakeven analysis

14. Advertising and Promotion

Assesi current promotional activities

. Compare advantages/alsadvantages of difecent midia

[']al: promotional activities

15. To you vecd a Conputer in Your Business?

- Enilose uses of micro-computers in small business

- Djerugs aristing hardward and software

Arsess poselble uses in your busiress

7.6. Eusil:ess Financial Modeljug

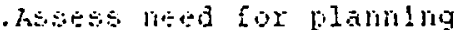

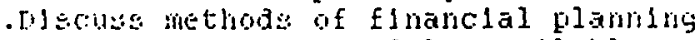

.Eus:ues plaming molels avallable

17. Are Yulu covered?

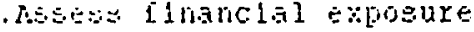

Revis jusurance needs/coverage

18. Supervisory sirills

Milntain employee self-esteen

Elicwurage emiployed participation

. Listen to cormunicate

19. Cultivating Happy, Productive Employees

- Assess erriloyee selection and training

- Evaluate compensation procedures

- Update policies and procedures

20. Where Have we Been and where To From Here?

. Review tax plarning

- Feview enM task: accomblshed

- Disciass benefit of program to your business 